\title{
Sulfur Degassing From Volcanoes: Source Conditions, Surveillance, Plume Chemistry and Earth System Impacts
}

\author{
Clive Oppenheimer1,2 \\ Bruno Scaillet1 and \\ Robert S. Martin4
}

1 Centre National de la Recherche Scientifique-Institut National des Sciences de, l'Univers, Université d'Orléans, Université François Rabelais de Tours, Institut des Sciences de la Terre d'Orléans, la rue de la Férollerie, Orléans 45071, France

2 Department of Geography, University of Cambridge, Downing Place, Cambridge CB2

3 EN, United Kingdom

3 School of Biological and Chemical Sciences, Queen Mary, University of London, United

Kingdom, co200@cam.ac.uk

\section{INTRODUCTION}

Despite its relatively minor abundance in magmas (compared with $\mathrm{H}_{2} \mathrm{O}$ and $\mathrm{CO}_{2}$ ), sulfur degassing from volcanoes is of tremendous significance. It can exert substantial influence on magmatic evolution (potentially capable of triggering eruptions); represents one of the most convenient opportunities for volcano monitoring and hazard assessment; and can result in major impacts on the atmosphere, climate and terrestrial ecosystems at a range of spatial and temporal scales. The complex behavior of sulfur in magmas owes much to its multiple valence states (-II, 0, IV, VI), speciation (e.g., $\mathrm{S}_{2}, \mathrm{H}_{2} \mathrm{~S}, \mathrm{SO}_{2}, \mathrm{OCS}$ and $\mathrm{SO}_{3}$ in the gas phase; $\mathrm{S}^{2-}, \mathrm{SO}_{4}{ }^{2-}$ and $\mathrm{SO}_{3}{ }^{2-}$ in the melt; and non-volatile solid phases such as pyrrhotite and anhydrite), and variation in stable isotopic composition $\left({ }^{32} \mathrm{~S},{ }^{33} \mathrm{~S},{ }^{34} \mathrm{~S}\right.$ and ${ }^{36} \mathrm{~S}$; e.g., Métrich and Mandeville 2010). Sulfur chemistry in the atmosphere is similarly rich involving gaseous and condensed phases and invoking complex homogeneous and heterogeneous chemical reactions. Sulfur degassing from volcanoes and geothermal areas is also important since a variety of microorganisms thrive based on the redox chemistry of sulfur: by reducing sulfur, thiosulfate, sulfite and sulfate to $\mathrm{H}_{2} \mathrm{~S}$, or oxidizing sulfur and $\mathrm{H}_{2} \mathrm{~S}$ to sulfate (e.g., Takano et al. 1997; Amend and Shock 2001; Shock et al. 2010). Understanding volcanic sulfur degassing thus provides vital insights into magmatic, volcanic and hydrothermal processes; the impacts of volcanism on the Earth system; and biogeochemical cycles. Here, we review the causes of variability in sulfur abundance and speciation in different geodynamic contexts; the measurement of sulfur emissions from volcanoes; links between subsurface processes and surface observations; sulfur chemistry in volcanic plumes; and the consequences of sulfur degassing for climate and the environment.

\section{Geodynamics and the geochemical behavior of sulfur}

The sulfur released by magmas in volcanic emissions may derive from three different sources: dissolved in the silicate liquid, present in a coexisting gas phase at depth, or from the breakdown of sulfur-bearing minerals. Both the amount of sulfur locked in solid compounds (essentially sulfates and sulfides) and that dissolved in silicate melt under pre-eruptive conditions can be accurately measured. The greatest unknown in assessing the budget of sulfur that can potentially be sourced from degassing magmas comes from the presence of an 
"excess" gas phase at depth, i.e., in the reservoir where the magma resides for a certain time prior to eruption (Shinohara 2008). This possibility introduces the difficulties of establishing the sulfur content of the gas phase in addition to the abundance of gas relative to minerals and silicate melt phases. Neither variable can be assessed by direct observation or geophysical investigations. We rely, therefore, on indirect means to estimate the abundance of gas and its sulfur content at depth. In the following subsections, we first consider the case for subduction zone magmas, concerning which considerable progress has been achieved in recent years, and then review the evidence for hot spot and ocean ridge environments.

\section{Subduction zones}

Although prior research had already suggested the presence of a gas phase at depth in arc magmas (Rose et al. 1982), the first eruption for which the case for an "excess" gas phase was strongly articulated was that of El Chichón in 1982, thanks to the efforts of the late Jim Luhr. He carried out detailed petrological work on this sulfide- and sulfate-bearing andesitic magma (Luhr et al. 1984 Luhr 1990). Scaling estimates of pre-eruptive dissolved sulfur (measured in crystal-hosted melt inclusions) by the eruption magnitude suggested a sulfur release as much as two orders of magnitude lower than the $\mathrm{SO}_{2}$ measured by satellite remote sensing techniques (see later section). This great discrepancy between observations and petrologic estimates led Luhr et al. (1984) to suggest that the "excess" sulfur (i.e., that missing from the petrological calculation) was most probably stored in a coexisting gas phase in the reservoir.

This approach revealed a similar picture for the next major sulfur-rich volcanic cloud, that released by the 1991 Plinian eruption of Mt. Pinatubo in the Philippines. Here again, comparison between remote sensing measurements and petrological calculations led Westrich and Gerlach (1992) to conclude the existence of an "excess" gas phase in which most of the sulfur was stored prior to eruption. An alternative scenario for sulfur release during the Pinatubo eruption involving anhydrite breakdown during decompression was proposed (Rutherford and Devine 1996) but such a mechanism is not supported on kinetic grounds (Gerlach et al. 1996). The evidence for excess sulfur stored in a gas phase has been reported since for a number of other active volcanoes, including Mt. St. Helens (USA, Gerlach and McGee 1994), Redoubt (USA, Gerlach et al. 1994), Nevado del Ruíz (Colombia, Williams et al. 1986; Sigurdsson et al. 1990), several Chilean volcanoes (Andres et al. 1991; Matthews et al. 1999) and Anatahan (Mariana Islands) during its 2003 eruption (de Moor et al. 2005). Thanks largely to satellite remote sensing estimates, there is, therefore, compelling evidence supporting the concept that arc magmas, in particular those of evolved composition, can hold a significant part of their sulfur budget in a gas phase at depth. The observed sulfur budgets point to a gas phase amounting to a few wt $\%$ of the magma, with a sulfur content (of the gas) of up to a few wt $\%$.

Another method used to retrieve gas abundance in magma reservoirs is based on the geochemical behavior of trace elements that are prevalent either in the silicate melt or in the gas phases (Wallace and Edmonds, 2011 this volume). If the partition coefficients of those elements are known, then it is possible to calculate the amount of a gas phase in the reservoir given a series of melt inclusions related to each other by a gas-melt fractionation process. Based on this assumption, it is possible to evaluate the amount of gas present in the various parcels of magma sampled by the melt inclusions. Such an approach has been applied successfully to the Bishop Tuff eruption (Wallace et al. 1995, 1999) and also to the 1991 Pinatubo eruption (Wallace and Gerlach 1994). Of particular importance is the latter case because the calculated abundance of gas in the reservoir (up to $5 \mathrm{wt} \%$ ) corresponds to a sulfur 
yield similar to that measured independently by satellite remote sensing (around $9 \mathrm{Tg} \mathrm{S}$ ). Consideration of percolation theory led Wallace (2001) to conclude that this value might represent a fluid mechanical threshold. In other words, a magma reservoir cannot sustain more than $5 \mathrm{wt} \%$ of gas, beyond which all excess gas arising from further crystallization or supplied from deeper levels to the upper regions of the reservoir, is lost via percolation of gas through a permeable bubble network to the top of the reservoir and into the hydrothermal system.

The sulfur content of gas in a magma reservoir can be also estimated from thermodynamic calculations. Using standard concepts of homogeneous equilibria in the C-O-H-S system, as pioneered by Holloway $(1977,1987)$, it is possible to calculate the abundance and nature of volatile species present in the gas phase. Given the potentially wide range of application of such an approach, its basic principles are summarized here.

The gas phase is modeled in the C-O-H-S system, which typically accounts for over 95 mol\% of the bulk composition of volcanic gases. Halogens are next in abundance (Aiuppa et al. 2009) but though they potentially affect sulfur solubility in relatively oxidized silicate melts (Botcharnikov et al. 2004; Webster et al. 2009), their role in affecting sulfur behavior in magmatic gases is neglected here for simplicity. Species typically considered are $\mathrm{H}_{2} \mathrm{O}, \mathrm{H}_{2}$, $\mathrm{CO}_{2}, \mathrm{CO}, \mathrm{CH}_{4}, \mathrm{~S}_{2}, \mathrm{SO}_{2}, \mathrm{H}_{2} \mathrm{~S}$ and $\mathrm{O}_{2}$. The five coupled equilibria that govern the abundances of these species in the gas are:

$$
\begin{aligned}
& \mathrm{H}_{2} \mathrm{O}=\mathrm{H}_{2}+\frac{1}{2} \mathrm{O}_{2} \\
& \mathrm{CO}+\frac{1}{2} \mathrm{O}_{2}=\mathrm{CO}_{2} \\
& \mathrm{CH}_{4}+2 \mathrm{O}_{2}=2 \mathrm{H}_{2} \mathrm{O}+\mathrm{CO}_{2} \\
& \frac{1}{2} \mathrm{~S}_{2}+\mathrm{O}_{2}=\mathrm{SO}_{2} \\
& \frac{1}{2} \mathrm{~S}_{2}+\mathrm{H}_{2}=\mathrm{H}_{2} \mathrm{~S}
\end{aligned}
$$

with the corresponding equilibrium constants:

$$
\begin{aligned}
& K_{1}=\frac{\left(f_{O_{2}}^{1 / 2} \times f_{H_{2}}\right)}{f_{H_{2} O}} \\
& K_{2}=\frac{f_{C O_{2}}}{\left(f_{O_{2}}^{1 / 2} \times f_{C O}\right)} \\
& K_{3}=\frac{\left(f_{C O_{2}} \times f_{H_{2} O}^{2}\right)}{\left(f_{C H_{4}} \times f_{O_{2}}^{2}\right)} \\
& K_{4}=\frac{f_{S O_{2}}}{\left(f_{O_{2}} \times f_{S_{2}}^{1 / 2}\right)} \\
& K_{5}=\frac{f_{H_{2} S}}{\left(f_{H_{2}} \times f_{S_{2}}^{1 / 2}\right)}
\end{aligned}
$$


where $f_{i}$ is the fugacity of species $i$. In such a system at any fixed pressure $(P)$ and temperature $(T)$, the knowledge of three additional intensive parameters constrains species' proportions (Holloway 1987). The equilibrium constants $\mathrm{K}_{i}$ can be computed from standard thermodynamic databases (Symonds and Reed 1993). The additional relationships needed are:

$f_{i}=X_{i} \gamma_{i} P$
$\sum X_{i}=1$

where $X_{i}$ is the mole fraction of species $I$, and $\gamma_{i}$ the fugacity coefficient (a correction for nonideality; $\gamma_{i}=1$ for an ideal gas) at pressure $P$ and temperature $T$. Several equations of state (EOS) enable calculation of the fugacity coefficient of the main species of interest (see, for instance, Ferry and Baumgartner 1987) but, in the context of the present review, we focus on low-pressure conditions ( $<300 \mathrm{MPa}$ ) where most magmatic reservoirs reside, and for which there is thus little difference between the various EOS outcomes. In the following, use will be made of the classic MRK EOS introduced to geologists by John Holloway in 1977.

The most straightforward way to apply the above approach is to rely on information given by melt inclusions regarding pre-eruptive dissolved volatiles. Conventional micro-analytical tools (FTIR, SIMS, EMPA) permit accurate determination of the most common volatile species dissolved in silicate glasses, notably the bulk contents of $\mathrm{H}_{2} \mathrm{O}, \mathrm{CO}_{2}$ and $\mathrm{S}$ (Ripley et al. 2011, this volume). Once these quantities are known, it suffices to have appropriate thermodynamic models of volatile solubilities (e.g., Dixon et al. 1995; Zhang 1999; Moretti et al. 2003; Behrens et al. 2004; Clemente et al. 2004) to shift from concentrations to corresponding fugacities (i.e., $f_{\mathrm{H} 2 \mathrm{O}}, f_{\mathrm{CO} 2}$ or $f_{\mathrm{S} 2}$ ), which are the input parameters needed to solve the above set of equations (e.g., Anderson et al. 1989; Scaillet and Pichavant 2003, 2005). In general, thermobarometry based on mineral-mineral or mineral-melt equilibria (see Putirka 2008) provides further constraints on both temperature and $f_{\mathrm{O} 2}$. The main unknown variable with respect to most active volcanoes is the reservoir depth, which can be evaluated either from phase equilibria (e.g., Rutherford et al. 1985; Johnson and Rutherford 1989; Martel et al. 1998; Cottrell et al. 1999; Scaillet and Evans 1999; Costa et al. 2004; Di Carlo et al. 2006), or from gas saturation systematics as first shown by Anderson et al. (1989) for the Bishop tuff for the C-O-H system. In the latter method, one seeks the pressure value which, for a given set of $T, f_{\mathrm{H} 2 \mathrm{O}}$, and $f_{\mathrm{CO} 2}$ conditions, fulfills the constraint of $\sum X_{i}=1$.

Application of this thermodynamic approach to the C-O-H-S sytem was first attempted by Scaillet and Pichavant (2003) for several recent arc eruptions, for which the key intensive variables mentioned above were reasonably well known. The results are shown in Figure 1, where it can be appreciated that the sulfur content in the gas amounts, at most, to 5-6 wt $\%$ (or less than $6 \mathrm{~mol} \%$ of $\mathrm{H}_{2} \mathrm{~S}$ and $\mathrm{SO}_{2}$ ) for the investigated samples. Another important aspect is the considerable variability between magmas of the studied eruptions, with sulfur content as low as $0.1 \mathrm{wt} \%$ (less than $0.1 \mathrm{~mol} \%$ ) in some cases. This is despite the fact that all considered eruptions represent a single tectonic environment, namely subduction-zone volcanism. The reasons for such variability are certainly complex and include source heterogeneity (in terms of sulfur content); the vagaries associated with the various fractionation mechanisms that can affect a magma between its source and the shallow reservoir; and the different types of 
interactions between host rocks and magma or during magma mixing, both of which are commonplace in arc environments.

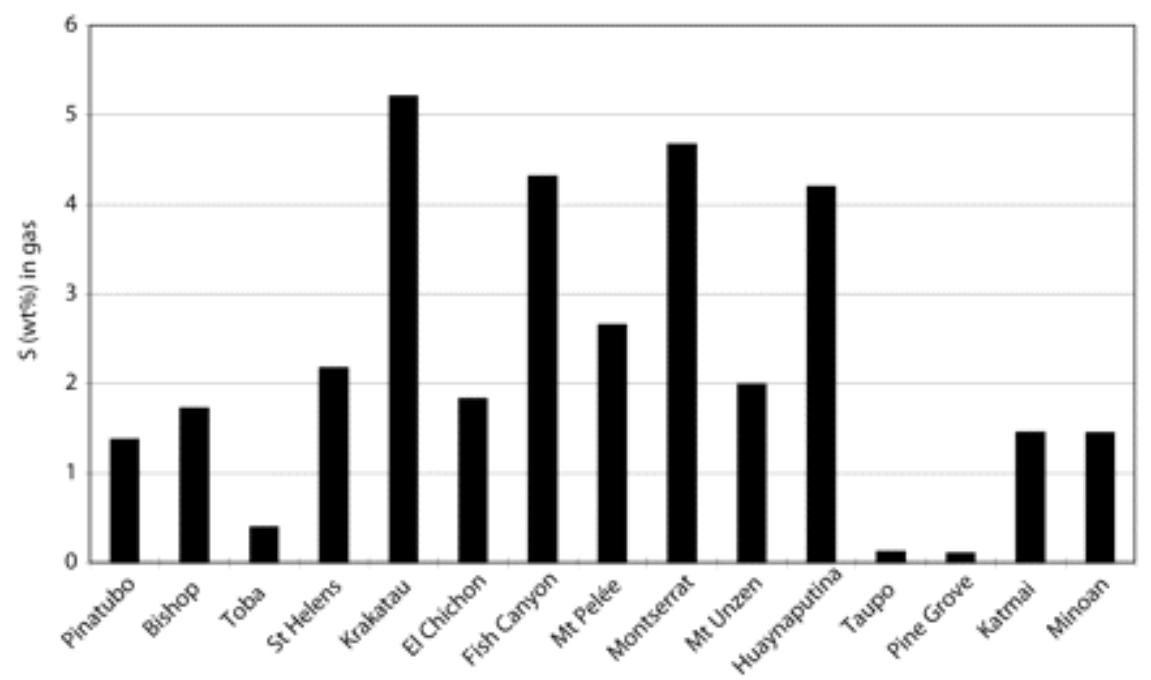

Figure 1. : Plots of sulfur concentration of the pre-eruptive gas phase for several historical eruptions in arc settings. The sulfur content has been calculated using a thermodynamic approach (see text and Scaillet and Pichavant 2003).

Whatever the causes, such diversity clearly indicates that evaluating the actual sulfur content of the gas phase present in a reservoir feeding any active volcano needs to be carried out on a case-by-case basis. It was also shown by Scaillet and Pichavant (2003) that in order to make the volcanic gas data match with computed gas composition at depth, the reservoir must already be saturated with at least $1 \mathrm{wt} \%$ gas phase, a conclusion consistent with evidence from remote sensing observations discussed above. The calculation of the deep-gas composition also reveals that it is, in general, somewhat richer in sulfur species' than corresponding volcanic exhalations, with the sum of sulfur-bearing species approaching a few mol\% (for evolved magma compositions such as dacites), whilst in gases from volcanic arcs, sulfur-bearing species abundances are less than 1 mol\% (see Symonds et al. 1994). This difference is obviously related to the fact that, upon ascent and with reduced pressure, the water originally dissolved in the silicate liquid in the reservoir (generally in the range 4-7 $\mathrm{wt} \%$ ) is almost totally lost to the gas phase, which thus becomes very water rich. Another difference worthy of note is the fact that high-pressure gases are generally dominated by $\mathrm{H}_{2} \mathrm{~S}$, while the reverse is observed in volcanic gases, as a result of the pressure effect on equilibria governing the relative abundance of $\mathrm{H}_{2} \mathrm{~S}$ and $\mathrm{SO}_{2}$ (see below).

This same method has been applied to volcanoes in non-arc settings by Scaillet et al. (2003), with the goal of estimating atmospheric sulfur yields of several major volcanic eruptions capable of impacting climate at a regional-to-global scale. Figure 2 compares the amounts of sulfur released by several eruptions, as derived by the improved petrologic approach, with those obtained by remote sensing techniques. In the derivation of petrologically-based values it is assumed that the magma coexisted with $5 \mathrm{wt} \%$ gas. Clearly, the generally good agreement observed between the two data sets supports the idea that most magmas contain a significant proportion of gas prior to eruption. Except for some outliers, the extended database provided by Scaillet et al. (2003) confirms that the sulfur content of the gas phase in silicic-tointermediate arc magmas is always below $10 \mathrm{wt} \%$, with an average of around $3 \mathrm{wt} \%$. When 
plotted against silica content of the magma, only a weak negative correlation appears: mafic magmas showing a tendency to be slightly richer in sulfur than silicic ones (Fig. 3). The lack of a more pronounced negative correlation contradicts the common view that silicic magmas tend to be poorer in sulfur than mafic ones, because of their intrinsic lower sulfur solubility: the latter fact is more than compensated for by the propensity of the gas phase to hold any sulfur present in the system (e.g., Scaillet et al. 1998; Keppler 1999, 2010), especially under oxidized conditions (Scaillet et al. 1998).

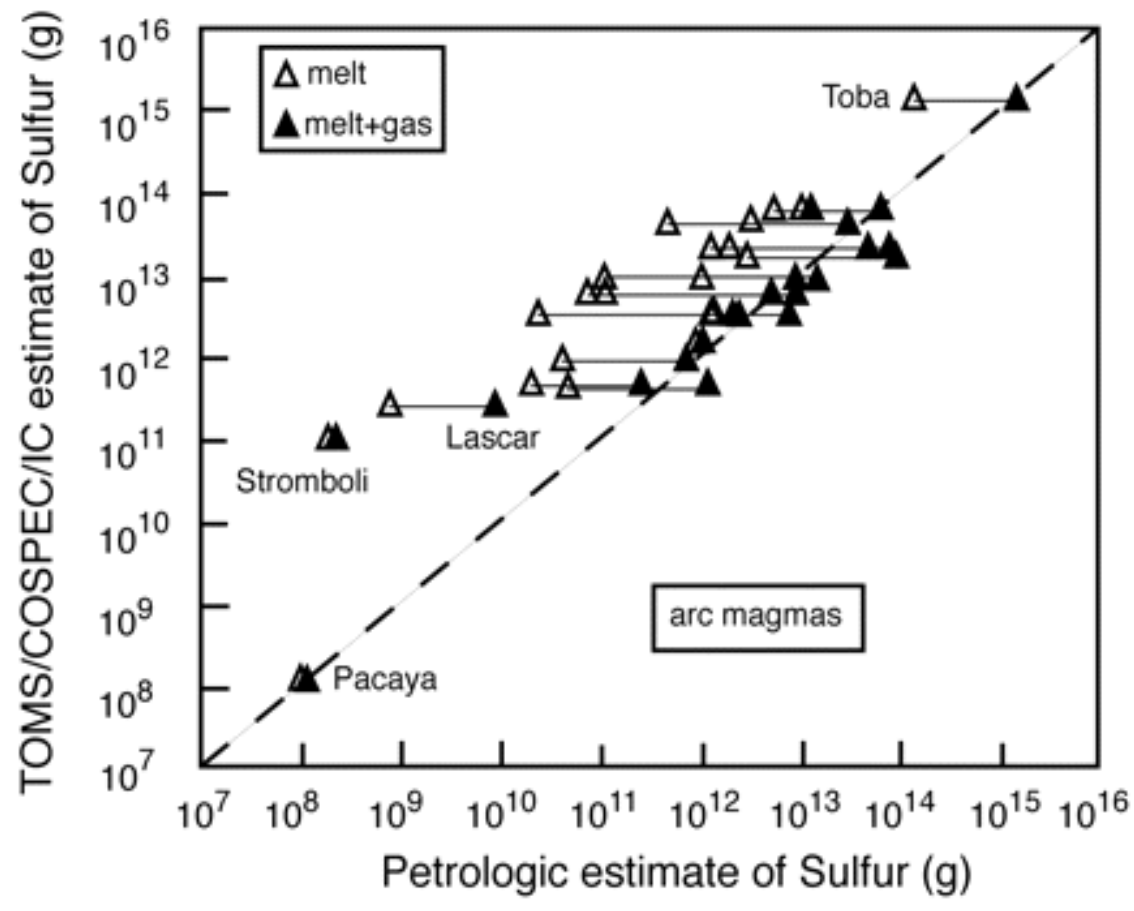

Figure 2. : Plot showing comparison of sulfur yields for several historical volcanic eruptions estimated from remote sensing data (Table 3) and petrological and thermodynamic constraints, assuming that the gas phase in the pre-eruptive reservoir amounts to $5 \mathrm{wt} \%$ (from Scaillet et al. 2003). The results for sulfur yields obtained only from melt degassing are also shown. 


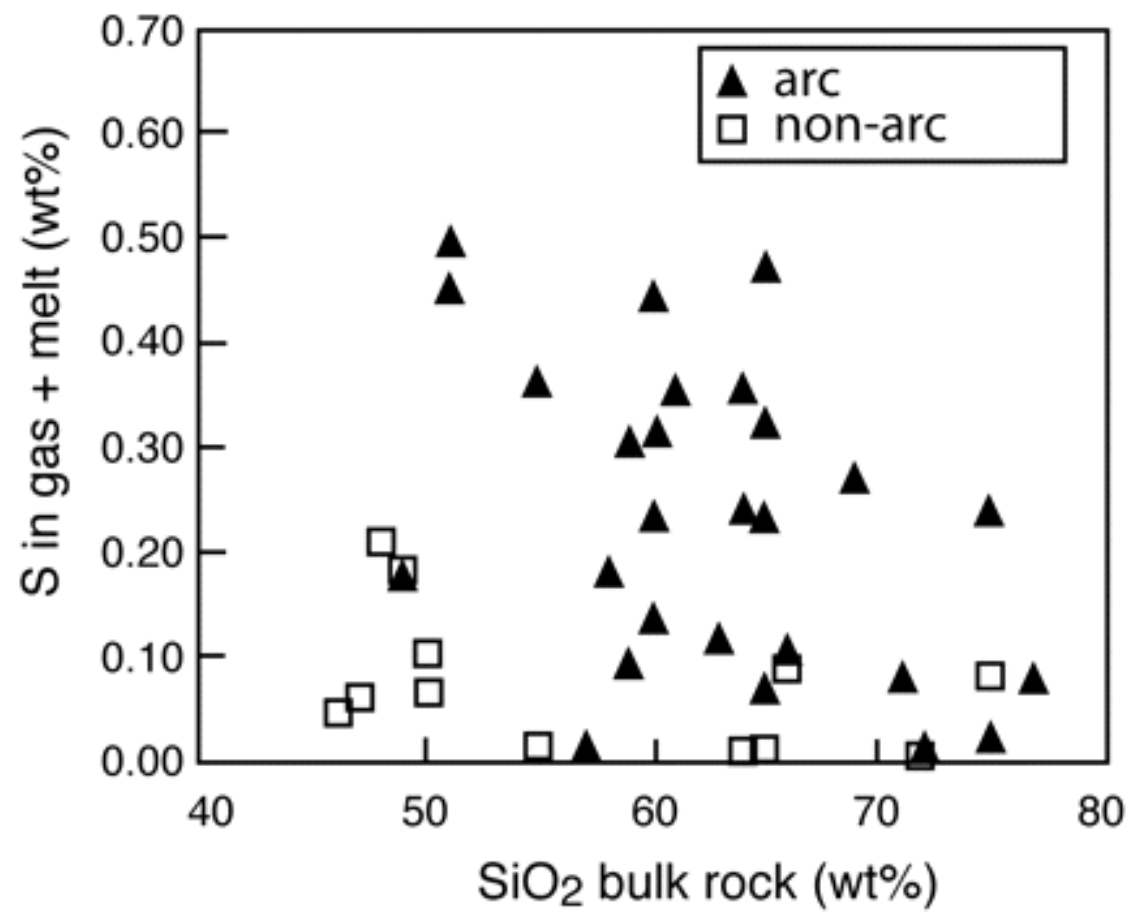

Figure 3. : Plot of relationship between the bulk content of $\mathrm{S}$ in various magmas erupted at arc and non-arc volcanoes versus the magma $\mathrm{SiO}_{2}$ content (from Scaillet et al. 2003

However, it must be pointed out that mafic arc magmas seldom erupt and among those rare cases, only a handful have had their pre-eruptive conditions well constrained. The currently available information on the sulfur content of gas in mafic arc magmas relies on a very limited data base. One of the best understood arc basalts is that erupted by Stromboli volcano, whose plumbing system is constrained by both phase equilibria (Di Carlo et al. 2006;

Pichavant et al. 2009), detailed melt inclusion work (Métrich et al. 2001; Bertagnini et al. 2003, 2008), and volcanic gas emission data (Allard et al. 1994; Burton et al. 2007a; Aiuppa et al. 2010; Allard 2010). Here, the observations point to a deep reservoir located at pressures of 200-300 MPa, and connected to a very shallow reservoir residing at pressures equivalent to around 10-30 MPa. This, in turn, feeds the persistent, mildly explosive activity that typifies Stromboli. The calculation of the gas phase composition in the deep reservoir at 200-300 MPa (Scaillet and Pichavant 2005) indicates a sulfur content in the range of 0.3-6 wt $\%$, which is similar to that inferred for more silicic compositions. It is worth stressing that these calculations depend strongly on $f_{\mathrm{S} 2}$, which remains difficult to constrain for $\mathrm{H}_{2} \mathrm{O}$-rich arc basalt, owing to the lack of appropriate thermodynamic models for sulfur solubility in hydrous mafic liquids. This is clearly an area where more experimental work is needed. It is thus difficult to know whether the Stromboli case is widely representative of other mafic arc magmas in respect of their sulfur content and yield. Other basaltic volcanoes should have the nature of their plumbing systems better elaborated in order to answer this important question.

\section{Ocean ridge environments}

Although most magmas by volume are produced and erupted at ocean ridges, very little is known about pre-eruptive gas composition for this tectonic setting. This is due in large part to the difficulties of observing and sampling submarine volcanism. One of the closest analogs is seen in the rifting, diking and volcanism of the Afar region (Ferguson et al. 2010), though it is 
also a challenging place to conduct fieldwork. Hence, despite collection of some relevant volcanic gas composition data (e.g., Giggenbach and Le Guern 1976; Gerlach 1980), we lack modern petrological data (volatiles in melt inclusions) for corresponding magmas, suitable for constraining system behavior at depth as achieved for subduction zones (e.g., Scaillet and Pichavant 2003). Icelandic volcanism has been better studied, with some detailed information on dissolved volatiles present in magma reservoirs (Métrich et al. 1991; Moune et al. 2009) but here, too, there are very few data on related magmatic gas compositions. Therefore, for this volumetrically important category of magmas we must calculate gas composition at depth using available constraints on dissolved volatiles, which have been well established for a number of dredged oceanic basalts (see Wallace and Edmonds 2011, this volume).

One salient feature of mid-ocean ridge magmatism is its very dry character, dissolved $\mathrm{H}_{2} \mathrm{O}$ lying in the range of $0.1-0.5 \mathrm{wt} \%$, or even less than $0.1 \mathrm{wt} \%$ (Saal et al. 2002). Dissolved sulfur contents are also well characterized, falling in the range of 800-1200 ppm for primitive end members (Wallace and Carmichael 1992; Saal et al. 2002). Carbon dioxide concentrations are more controversial: some argue that mid-ocean ridge basalts (MORB) are gas-undersaturated under pre-eruptive conditions (Saal et al. 2002), while others (e.g., Sarda and Graham 1990) argue for $\mathrm{CO}_{2}$ contents of magmas well above solubility values at pressures of magma storage in the upper oceanic crust (100-200 MPa). Since the case for undersaturation has been disputed on thermodynamic grounds (Scaillet and Pichavant 2004), we show in Figure 4 the calculated C-O-H-S gas phase composition as a function of $f_{\mathrm{O} 2}$ at $1280{ }^{\circ} \mathrm{C}$ and $40 \mathrm{MPa}$ for fixed melt $\mathrm{H}_{2} \mathrm{O}$ content of $0.08 \mathrm{wt} \%$ and sulfur melt content around $800 \mathrm{ppm}$, which are averages for primitive MORB melts (Saal et al. 2002) (note that the bulk $\mathrm{CO}_{2}$ content of the magma need not be known to carry out the calculations since fixing $f_{\mathrm{H} 2 \mathrm{O}}$ and $f_{\mathrm{S} 2}$ (at a given $P$ and $T$ ) automatically fixes $f_{\mathrm{CO} 2}$, and hence $X_{\mathrm{CO} 2}$, in the gas). These data can be taken to illustrate the possible sulfur contents of the gas phase coexisting with MORB in reservoirs associated with axial ridges. 

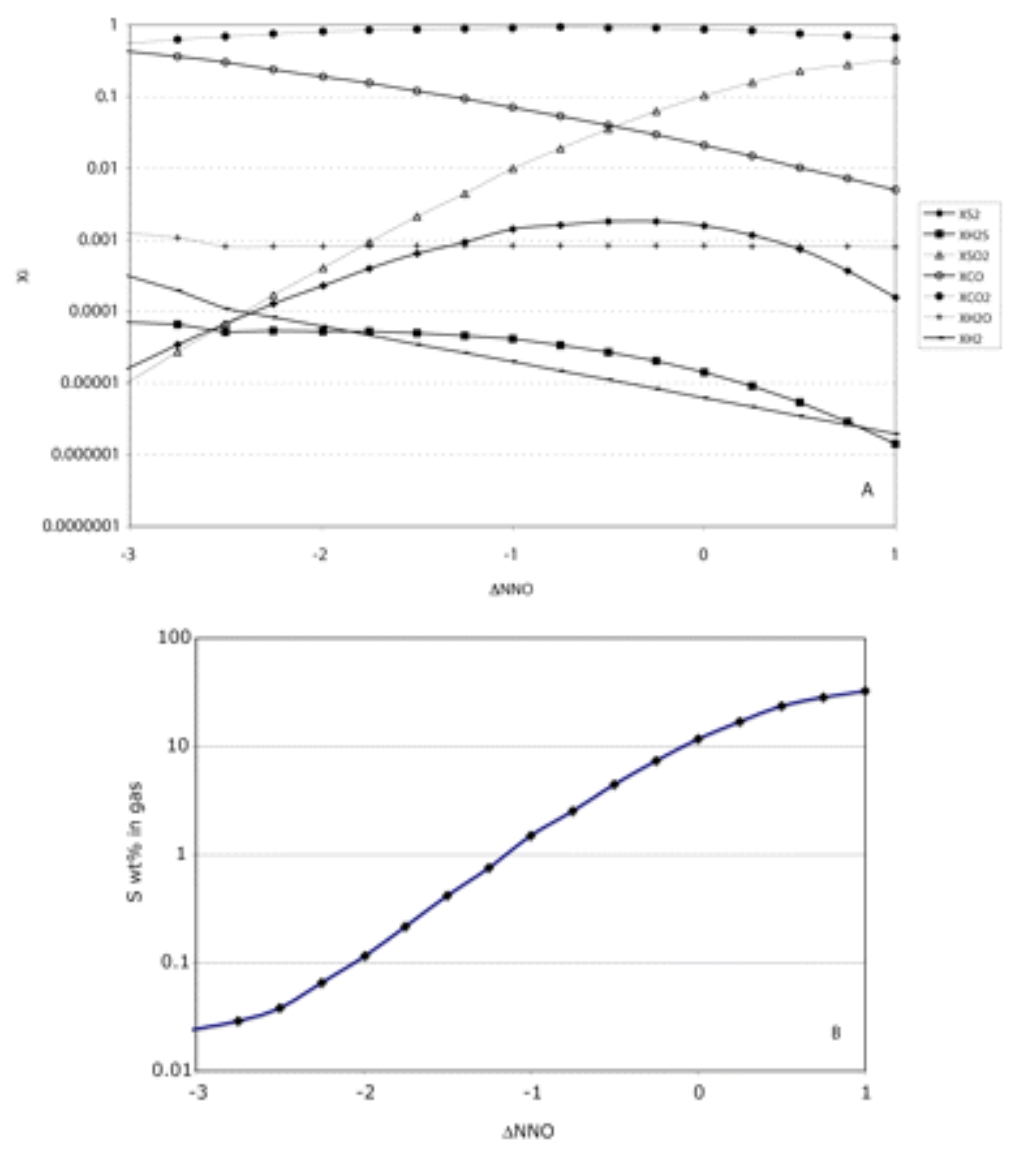

Figure 4. : Plots of (a) the variation of fluid species abundances versus $f$ (in log units relative to the nickel- $\mathrm{O}_{2}$ nickel oxide buffer), calculated for volatile conditions of $\mathrm{H}_{2} \mathrm{O}=0.06 \mathrm{wt} \%$ and $850 \mathrm{ppm}$ dissolved sulfur, which correspond to primitive Mid Ocean Ridge Basalts (Saal et al. 2002). The calculations were made for a pressure of $40 \mathrm{MPa}$ and a temperature of 1280 ${ }^{\circ} \mathrm{C}$. (b) Evolution of the sulfur content of the gas phase with $f_{\mathrm{O} 2}$, corresponding to the gas composition shown in (a).

These calculations illustrate a well-known feature, that the species abundances in the gas phase vary a lot with $f_{\mathrm{O} 2}$, with $\mathrm{CO}_{2}$ being the most abundant species in MORBs (Mathez 1984). Sulfur-bearing species are generally present below 1 mol\% at $f_{\mathrm{O} 2}$ below NNO-1, with corresponding sulfur concentration in the gas being below $1 \mathrm{wt} \%$ for this $f_{\mathrm{O} 2}$ range, or even below $0.1 \mathrm{wt} \%$ at around $\mathrm{NNO}-3$. In contrast, at $f_{\mathrm{O} 2}$ greater than $\mathrm{NNO}-1, \mathrm{SO}_{2}$ abundances increase quite significantly to the point that it becomes the second most abundant gas species (after $\mathrm{CO}_{2}$ ), with sulfur concentration exceeding $20 \mathrm{wt} \%$ at around $\mathrm{NNO}+1$. This illustrates the important point that, besides $f_{\mathrm{S} 2}$ (or melt sulfur content), the master variable required is precise knowledge of redox state. This remains an inssue: despite decades of effort by various groups (e.g., Christie et al. 1986; Carmichael 1991; Ballhaus 1993; Bézos and Humler 2002; Li and Lee 2005; Mallmann and O'Neill 2009) there is still no consensus on whether MORBs are either strongly (i.e., $f_{\mathrm{O} 2}<\mathrm{NNO}-2$ ), or moderately (FMQ-NNO) reduced, or could even share the same redox state as mafic arc magmas (Mallmann and O'Neill 2009). If one accepts that most MORBs have pre-eruptive $f_{\mathrm{O} 2}$ at or below NNO-2, then the sulfur fraction stored in the gas is small, below $1000 \mathrm{ppm}$, with a negligible contribution to the bulk amount of sulfur degassed. In contrast, if the MORB $f_{\mathrm{O} 2}$ is around $\mathrm{NNO}$, sulfur contained in the gas approaches or may even exceed $10 \mathrm{wt} \%$, in which case the gas phase contribution to eruptive loss of 
sulfur becomes important, or even dominant, relative to that dissolved in the melt phase, although we have few constraints on the amounts of gas present in the reservoir.

Gas compositions collected from subaerial volcanoes associated with divergent plates (Ardoukoba, Erta 'Ale, Surtsey; see Giggenbach and Le Guern 1976; Allard et al. 1977; Gerlach 1980; Sawyer et al. 2008a) have sulfur contents in the range of 10-30 wt\%. If those volcanic centers are representative of their deep-oceanic counterparts, it may indicate that MORBs are more oxidized than generally believed. To conclude, the redox state of magmas at divergent plates still needs to be better evaluated - a conclusion that also applies to many, if not all, other magmas! This issue remains a priority for improving our understanding of sulfur-related magmatic processes.

\section{Hot spots}

The few hot spots where volcanism is presently active include Hawaii and Réunion. We also include Etna in this discussion although its tectonic setting is especially complex and contested (e.g., Schiano et al. 2001) with chemical characteristics of the magmas pointing to either hot spot or arc settings. Thus, any conclusions drawn from the Etna case should be viewed cautiously. Volcanic gas emissions from both Hawaii and Etna have been studied in considerable detail over the last half century, both using conventional approaches, as summarized below and by Symonds et al. (1994), and with more recently developed groundbased remote sensing tools (see below). Volcanic gases emitted at la Réunion are less well characterized as there is little degassing between eruptions (e.g., Toutain et al. 2002). In all three cases, a wealth of microanalytical work aimed at determining pre-eruptive dissolved volatile contents has been undertaken (e.g., Dixon et al. 1997; Bureau et al. 1998, 1999; Wallace and Anderson 1998; Dixon and Clague 2001; Wallace 2002; Spilliaert et al. 2006). Despite some significant variations between the three volcanoes, it appears that hot spots fall roughly in between oceanic and arc magmas, in terms of their pre-eruptive $\mathrm{H}_{2} \mathrm{O}$ contents $(0.4-$ $3 \mathrm{wt} \%$ ) and redox state (NNO-NNO+1), although considerable uncertainties remain concerning redox state evaluation or significance (Gerlach 2004a; Roeder et al. 2004). The pre-eruptive melt sulfur contents are somewhat higher than for MORBs at comparable levels of $\mathrm{FeO}$ content, ranging between 1000 to 2000 ppm (Bureau et al. 1999; Dixon and Clague 2001), and reaching $3000 \mathrm{ppm}$ in the $\mathrm{H}_{2} \mathrm{O}$-rich variety of basaltic magma erupted at Etna (Spilliaert et al. 2006).

The gas phase composition in the magma reservoir of hot-spot volcanoes can be computed, as illustrated for MORBs, assuming a pressure depth for the shallow reservoir in the range 100 $200 \mathrm{MPa}$ and various contents for key volatiles, based on petrological data summarized above. Figure 5 shows the variations of sulfur content of the gas phase as a function of $f_{\mathrm{O} 2}$, for various $\mathrm{H}_{2} \mathrm{O}$ contents and $f_{\mathrm{S} 2}$. For the latter, petrological investigations indicate that $f_{\mathrm{S} 2}$ of hotspot related basalts is within the range of $0.1-100 \mathrm{kPa}$ (Wallace and Carmichael 1992). As already pointed out for MORBs, these calculations show clearly that, in general, the sulfur content of gas remains below $0.1 \mathrm{wt} \%$ at $f_{\mathrm{O} 2}$ below $\mathrm{NNO}$ (hence, to a first approximation, the gas contribution to the bulk sulfur budget can be ignored). Above this $f_{\mathrm{O} 2}$ threshold, the sulfur content can increase dramatically, even becoming the dominant constituent of the gas phase. Note that, under fairly reduced conditions (NNO-2), the gas can become quite sulfur-rich if the magma has a dissolved $\mathrm{H}_{2} \mathrm{O}$ content of $3 \mathrm{wt} \%$ or more. However, such elevated $\mathrm{H}_{2} \mathrm{O}$ levels have not been documented for reduced terrestrial basalts (but see Gaillard and Scaillet 2009 for the case of Mars). 


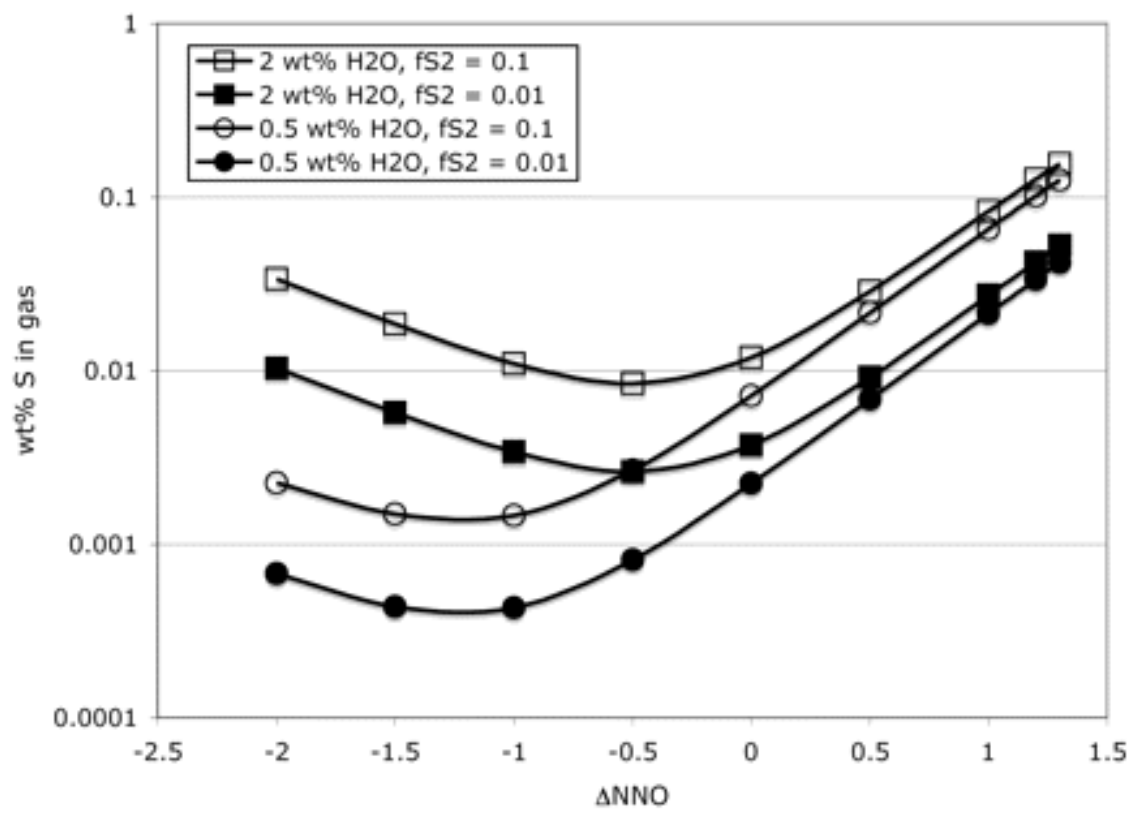

Figure 5. : Plot of variation in $\mathrm{S}$ content of gas versus $f_{\mathrm{O} 2}$ (in log units relative to the nickelnickel oxide buffer), calculated for $100 \mathrm{MPa}$ total pressure for a range of volatile contents and corresponding fugacities $\left(\mathrm{H}_{2} \mathrm{O}\right.$ and $\left.\mathrm{S}\right)$ corresponding to the conditions inferred for present day hot spot related basalts (see text).

Volcanic gases measured at other hot spots are essentially similar to those of Kilauea (Gerlach 1980, 1993), which have sulfur contents in the range of 20-30 wt\%, regardless of their more or less primitive character (i.e., degassed right after their arrival in the shallow reservoir or subsequently following equilibration with local conditions). Mt. Etna gases analyzed during the volcano's 1970 eruption are the most sulfur-rich volcanic gases so far collected, with a total sulfur content exceeding $50 \mathrm{wt} \%$ and $\mathrm{a} \mathrm{SO}_{2} / \mathrm{H}_{2} \mathrm{~S}$ molar ratio of around 100 (Huntingdon 1973; Gerlach 1979). The more recent activity has shown a significant decline in sulfur content of emitted gases (Allard et al. 2005), although Etna remains today one of the main sustained volcanic sources of sulfur to the atmosphere (Allard et al. 1991; Allard 1997). These two examples seem thus to suggest that hot-spot activity may coincide with elevated rates of sulfur emission. The high sulfur content of gases released also seems to indicate that magma redox state in the hot-spot context is somewhat oxidized relative to that of MORB.

This evidence once again highlights the important role of redox conditions in gas phase composition. In terms of the sulfur yield of past eruptions to the atmosphere, little can be said without good constraints on redox. The problem can be even more complex when decompression-related effects on magma $f_{\mathrm{O} 2}$ are taken into account. Recent modeling efforts, though rudimentary, indicate that volatile loss during decompression may strongly alter magma redox state (Moretti et al. 2003; Burgisser and Scaillet 2007; Burgisser et al. 2008; Gaillard and Scaillet 2009), adding further "noise" to the direct interpretation of volcanic gas data in terms of magma storage or generation conditions. Modeling the interplay between decompression and redox state of magmas and related gases is clearly another fruitful avenue for future research. 


\section{Flood basalts and silicic parts of large igneous provinces}

Interest in the potential global impacts of effusive volcanism has been fueled by the coincidence of several of the mass extinctions that punctuate the fossil record with the flood basalt episodes of large igneous provinces (LIPs; Rampino and Stothers 1988; Wignall 2001; Oppenheimer 2011). Estimated sulfur yields of such provinces are exceptional (e.g., Thordarson et al. 1996), and Ar-Ar chronometry has shown that the immense volumes of lava associated with flood basalts $\left(>10^{6} \mathrm{~km}^{3}\right)$ are erupted in comparatively short time periods For instance, the 30-Ma-old Ethiopian Plateau basalts erupted in under $1 \mathrm{Ma}$ (Hofmann et al. 1997) while the main eruptive phase of the Deccan traps (65.5 Ma old) was over within 0.5 $\mathrm{Ma}$ (Courtillot and Renne 2003). Such rapid eruption rates imply correspondingly high fluxes of sulfur and other volatiles to the atmosphere.

Self et al. (2008) analyzed melt inclusions in samples of the Deccan basalt and estimated that for each cubic kilometer of lava erupted, at least $3 \mathrm{Tg}$ of $\mathrm{SO}_{2}$ were released into the atmosphere (plus a comparable amount of $\mathrm{HCl}$ ). An individual pulse of $1000 \mathrm{~km}^{3}$ of magma would therefore release 4-5 Gt of $\mathrm{SO}_{2}$ (at least $200 \times$ as much as Pinatubo's eruption in 1991). We have very little idea how long each flow took to erupt but estimates vary from years to a few decades. A 10-year duration would correspond to a mean annual eruption rate of $100 \mathrm{~km}^{3}$ of lava and 10-20× more sulfur than emitted by Pinatubo in 1991, whose sulfate aerosol veil resulted in a $0.3-0.4{ }^{\circ} \mathrm{C}$ global average cooling for 2-3 years (see below; Hansen et al. 1996). Such massive eruption intensities along with the expanse of active lava covering the surface are thought to have generated especially energetic fire fountains and vigorous atmospheric updrafts, enabling a substantial fraction of the released sulfur gases to reach the stratosphere. Here, they would have oxidized to form a sulfate aerosol veil capable of climate forcing.

The estimates based on basaltic melt inclusions (Sharma et al. 2004; Self et al. 2008) set a lower limit on sulfur outgassing since, for equilibrium partitioning between melt and gas, any pre-eruptive magmatic gas must hold a finite amount of sulfur. In view of the preceding discussion of the importance of knowing $f_{\mathrm{O} 2}$ in order to evaluate the distribution of sulfur between silicate melt and gas phases (oxidized magmas tend to store a significant quantity of their sulfur inventory in the gas phase), an important factor in assessing the environmental impacts of flood basalt events is their redox state. Flood basalts with $f_{\mathrm{O} 2}$ in the range of NNOto $\mathrm{NNO}+1$ could yield sulfur outputs far higher than those estimated from melt inclusions alone. If, in contrast, the basalts have a lower redox state, then the sulfur content of the gas phase would be of negligible significance in calculating total sulfur emissions. Detailed investigations of volatile distribution have been carried out for the volcanoes of Hawaii, the modern archetype of the plume, or hot spot, regime viewed as parental to flood basalts. These have documented great regional variability in magma volatile contents and redox states (Dixon et al. 1988, 1991, 1997; Dixon and Clague 2001). If the Hawaiian plume can be considered as representative of hot spot magmatism through geological time, then the associated sulfur degassing is likely to have been very variable in time and space.

A further point to be stressed is that, along with the enormous quantities of basalt, flood provinces can include a silicic component (e.g., the Ethiopia-Yemen (30-Ma-old) and Etendeka-Paraná (133-Ma-old) provinces). The behavior of sulfur in such environments suggests that the silicic end-members could contribute significantly to LIP sulfur budgets (Scaillet and Macdonald 2006). A critical factor is the $\mathrm{Al} /(\mathrm{Na}+\mathrm{K})$ molar ratio of rhyolites. Peralkaline rhyolites have much higher sulfur solubilities than metaluminous magmas and, as a result, could convey comparable amounts of sulfur as the mafic counterpart of LIPs. In 
contrast, metaluminous rhyolites with much lower sulfur solubilities and different mode of production (i.e., by remelting previously dehydrated crust leading to particularly $\mathrm{H}_{2} \mathrm{O}$ - and $\mathrm{S}$ poor magmas, see Scaillet and Macdonald 2006), could be expected to have diminished impacts on the atmosphere and climate for eruptions of the same magnitude. This may be one reason for the limited correlation apparent between the intensity of environmental changes and the magnitude of coincident flood magmatism (Wignall 2001).

\section{MEASURING VOLCANIC SULFUR EMISSIONS}

Gas emissions from volcanoes are sourced within magmatic plumbing systems and their associated hydrothermal systems. Their vigor and chemical and isotopic composition can reveal much about subterranean processes, especially concerning the chemistry, differentiation, storage and transport of magmas and the relationships between degassing and eruptive style. The importance of gas emissions was recognized by early pioneers of volcanology, including Frank Perret and Thomas Jaggar, who bubbled fumarole gases into bottles of alkaline solution to trap the acidic species for subsequent analysis (Fig. 6a; Perret 1909, 1950; Jaggar 1940). This sampling method remains relevant today, with incondensable species held in the bottle's head space also studied (Table 1)

Table 1. : Representative compositions of high-temperature volcanic gas samples* in mol\%. Data from compilations in Giggenbach (1996), Oppenheimer (2003), Fischer (2008) and from individual analyses in Gerlach (1980), Oppenheimer et al. (2002b), Oppenheimer and Kyle (2008) and Sawyer et al. (2009).

\begin{tabular}{|c|c|c|c|c|c|c|c|c|c|c|}
\hline Volcano & $\begin{array}{c}\text { Kudriav } \\
\text { y, Kuril } \\
\text { Islands }\end{array}$ & $\begin{array}{c}\text { Augustin } \\
\text { e, USA }\end{array}$ & $\begin{array}{c}\text { Merapi, } \\
\text { Java, } \\
1994\end{array}$ & $\begin{array}{c}\text { Ngauruho } \\
\text { e, New } \\
\text { Zealand }\end{array}$ & $\begin{array}{c}\text { Showa } \\
\text { Shinza } \\
\text { n, } \\
\text { Japan }\end{array}$ & $\begin{array}{c}\text { Satsuma } \\
\text { Iwojima, } \\
\text { Japan }\end{array}$ & $\begin{array}{l}\text { Usu, } \\
\text { Japan }\end{array}$ & $\begin{array}{l}\text { Vulcan } \\
\text { o, Italy }\end{array}$ & $\begin{array}{c}\text { Momotomb } \\
\text { o, } \\
\text { Nicaragua, } \\
1982\end{array}$ & $\begin{array}{c}\text { Momotomb } \\
\text { o, } \\
\text { Nicaragua, } \\
2002\end{array}$ \\
\hline $\begin{array}{c}\text { Magma } \\
\text { type \& } \\
\text { environme } \\
\text { nt }\end{array}$ & $\begin{array}{c}\text { Basaltic } \\
\text { andesite, } \\
\text { island arc }\end{array}$ & $\begin{array}{l}\text { Andesite, } \\
\text { island arc }\end{array}$ & $\begin{array}{l}\text { Andesit } \\
\text { e, island } \\
\quad \text { arc }\end{array}$ & $\begin{array}{l}\text { Andesite, } \\
\text { island arc }\end{array}$ & $\begin{array}{c}\text { Dacite, } \\
\text { island } \\
\text { arc }\end{array}$ & $\begin{array}{l}\text { Rhyolite/basa } \\
\text { lt, island arc }\end{array}$ & $\begin{array}{l}\text { Rhyolit } \\
\text { e, island } \\
\text { arc }\end{array}$ & $\begin{array}{l}\text { Rhyolit } \\
\text { e, island } \\
\text { arc }\end{array}$ & $\begin{array}{c}\text { Basalt, } \\
\text { continental } \\
\text { arc }\end{array}$ & $\begin{array}{c}\text { Basalt, } \\
\text { continental } \\
\text { arc }\end{array}$ \\
\hline$T,{ }^{\circ} \mathbf{C}$ & 920 & 870 & 803 & 640 & 800 & 880 & 690 & 620 & 844 & 747 \\
\hline $\mathrm{H}_{2} \mathrm{O}$ & 95.3 & 84.77 & 8.7 & 96 & 98 & 97.3 & 99.3 & 86.1 & 95.05 & 96.25 \\
\hline $\mathbf{H}_{2}$ & 0.775 & 0.54 & 0.50059 & 0.142 & 0.63 & 0.607 & 0.2 & 0.151 & 0.87 & 0.3516 \\
\hline $\mathrm{CO}_{2}$ & 1.15 & 2.27 & 5.56 & 1.605 & 1.2 & 0.51 & 0.36 & 11.9 & 2.38 & 2.532 \\
\hline $\mathrm{CO}$ & 0.00084 & 0.016 & 0.0235 & 0.0042 & 0.0033 & 0.00172 & 0.00005 & 0.011 & 0.025 & 0.01122 \\
\hline $\mathrm{SO}_{2}$ & 2.05 & 6.98 & 0.98 & 1.02 & 0.043 & 0.818 & 0.032 & 0.68 & 0.7 & 0.2335 \\
\hline $\mathbf{H}_{2} \mathrm{~S}$ & 0.39 & & 0.134 & 0.68 & 0.0004 & 0.164 & 0.018 & 0.48 & 0.49 & \\
\hline $\mathrm{HCl}$ & 0.74 & 1.01 & 0.60794 & 0.25 & 0.053 & 0.5306 & 0.034 & 0.453 & 0.35 & 0.5276 \\
\hline HF & 0.096 & 0.086 & 0 & & 0.024 & 0.0277 & 0.006 & 0.101 & 0.029 & 0.03839 \\
\hline $\mathrm{CH}_{4}$ & $\begin{array}{c}<0.00000 \\
5\end{array}$ & & 0 & 0.00003 & 0.00071 & 0.0004 & 0.00057 & 0.00001 & & $<0.00003$ \\
\hline $\mathbf{N H}_{3}$ & & & 0 & & & 0.00013 & 0.0003 & 0.00056 & & 0.000072 \\
\hline $\mathbf{N}_{2}$ & 0.025 & 0.11 & 3.6047 & 0.15 & 0.057 & 0.008 & 0.0104 & 0.1068 & 0.08 & 0.05529 \\
\hline Ar & 0.00009 & 0.0025 & 0.04848 & 0.00105 & 0.00025 & 0.000058 & 0.0001 & 0.00012 & & 0.00011 \\
\hline $\mathrm{O}_{2}$ & 0.0176 & & 0.01797 & $<0.003$ & & $<0.0005$ & $<0.0001$ & $<0.0002$ & & $<0.00005$ \\
\hline $\mathrm{He}$ & 0.000014 & & $\begin{array}{c}0.00004 \\
7\end{array}$ & 0.000022 & & 0.000006 & $\begin{array}{c}0.00000 \\
2\end{array}$ & 0.00012 & & 0.00005 \\
\hline
\end{tabular}

OCS 


\begin{tabular}{|c|c|c|c|c|c|c|c|c|c|c|}
\hline Volcano & $\begin{array}{l}\text { Tolbachik } \\
\text {, } \\
\text { Kamchatk } \\
\text { a, } 1976\end{array}$ & $\begin{array}{l}\text { Kliuchevsk } \\
\text { oi, } \\
\text { Kamchatk } \\
\text { a }\end{array}$ & $\begin{array}{c}\text { Poas, Costa } \\
\text { Rica }\end{array}$ & $\begin{array}{c}\text { Galeras, } \\
\text { Colombi } \\
\text { a, } 1991\end{array}$ & $\begin{array}{c}\text { Mt. St. } \\
\text { Helens, } \\
\text { USA }\end{array}$ & $\begin{array}{c}\text { Oldoinyo } \\
\text { Lengai, } \\
\text { Tanzania } \\
, 1999\end{array}$ & $\begin{array}{c}\text { Nyiaragon } \\
\text { go, DR } \\
\text { Congo, } \\
2005\end{array}$ & $\begin{array}{c}\text { Erta } \\
\text { 'Ale, } \\
\text { Ethiop } \\
\text { ia }\end{array}$ & $\begin{array}{l}\text { Erebus, } \\
\text { Antrarctic } \\
\text { a, } 2004\end{array}$ & $\begin{array}{l}\text { Kilaue } \\
\text { a, } \\
\text { USA, } \\
\text { 1918** }\end{array}$ \\
\hline \multicolumn{11}{|c|}{ *except Lengai, Erebus and Nyiragongo, which were measured by open-path FTIR spectroscopy } \\
\hline \multicolumn{11}{|c|}{ ** sample J-8 in Gerlach (1980) already adjusted for $\mathrm{N}_{2}$ and $\mathrm{Ar}$ and with $\mathrm{Cl} 2$ reported as $\mathrm{HCl}$} \\
\hline $\begin{array}{c}\text { Magma } \\
\text { type \& } \\
\text { environme } \\
\text { nt }\end{array}$ & $\begin{array}{c}\text { Basalt, } \\
\text { continental } \\
\text { arc }\end{array}$ & $\begin{array}{l}\text { Basalt, } \\
\text { continental } \\
\text { arc }\end{array}$ & $\begin{array}{c}\text { Basalt/andesi } \\
\text { te, } \\
\text { continental } \\
\text { arc }\end{array}$ & $\begin{array}{c}\text { Andesite, } \\
\text { continent } \\
\text { al arc }\end{array}$ & $\begin{array}{l}\text { Dacite, } \\
\text { continent } \\
\text { al arc }\end{array}$ & $\begin{array}{c}\text { Carbonati } \\
\text { te, } \\
\text { continenta } \\
1 \\
\text { intraplate }\end{array}$ & $\begin{array}{l}\text { Basanite, } \\
\text { continental } \\
\text { intraplate }\end{array}$ & $\begin{array}{c}\text { Basalt, } \\
\text { incipie } \\
\text { nt } \\
\text { oceanic } \\
\text { ridge }\end{array}$ & $\begin{array}{l}\text { Phonolite, } \\
\text { continental } \\
\text { intraplate }\end{array}$ & $\begin{array}{l}\text { Basalt, } \\
\text { ocean } \\
\text { island }\end{array}$ \\
\hline$T,{ }^{\circ} \mathbf{C}$ & 1020 & 1100 & 940 & 642 & 710 & $570-590$ & 1100 & 1130 & $>1000$ & $<1200$ \\
\hline $\mathbf{H}_{2} \mathbf{O}$ & 98 & 97.73 & 95 & 91.48 & 98.9 & 75.6 & 70.54 & 79.4 & 57.9 & 37.11 \\
\hline $\mathbf{H}_{2}$ & 0.55 & 0.59 & 0.9 & 0.285 & 0.4 & & & 1.49 & & 0.49 \\
\hline $\mathrm{CO}_{2}$ & 0.04 & 0.12 & 1.35 & 5.98 & 0.88 & 24.4 & 23.68 & 10.4 & 36.4 & 48.91 \\
\hline CO & 0.0001 & 0.0012 & 0.012 & 0.0136 & 0.003 & 0.0787 & 0.86 & 0.46 & 2.33 & 1.5 \\
\hline $\mathrm{SO}_{2}$ & 0.05 & 0.09 & 2.83 & 0.8415 & 0.27 & 0.0197 & 4.55 & 6.78 & 1.4 & 11.87 \\
\hline $\mathrm{H}_{2} \mathrm{~S}$ & & 0.002 & & 0.5725 & & & & 0.62 & & \\
\hline HCl & 1.06 & 1.42 & 0.38 & 0.716 & 0.15 & & 0.26 & 0.42 & 0.69 & 0.08 \\
\hline HF & 0.28 & 0.25 & 0.015 & 0.062 & 0.03 & & 0.11 & & 1.27 & \\
\hline $\mathrm{CH}_{4}$ & & $<0.0001$ & 0.0004 & & 0.00003 & & & & & \\
\hline \multicolumn{11}{|l|}{$\mathbf{N H}_{3}$} \\
\hline $\mathbf{N}_{2}$ & & 0.004 & 0.1 & 0.041 & 0.12 & & & 0.18 & & \\
\hline Ar & & 0.000032 & & & 0.000025 & & & & & \\
\hline \multicolumn{11}{|l|}{$\mathrm{O}_{2}$} \\
\hline He & & & & 0.00032 & & & & & & \\
\hline OCS & & & & & & & 0.0023 & & 0.01 & \\
\hline
\end{tabular}

*except Lengai, Erebus and Nyiragongo, which were measured by open-path FTIR spectroscopy

** sample $\mathrm{J}-8$ in Gerlach (1980) already adjusted for $\mathrm{N}_{2}$ and $\mathrm{Ar}$ and with $\mathrm{Cl} 2$ reported as $\mathrm{HCl}$ 
(a)

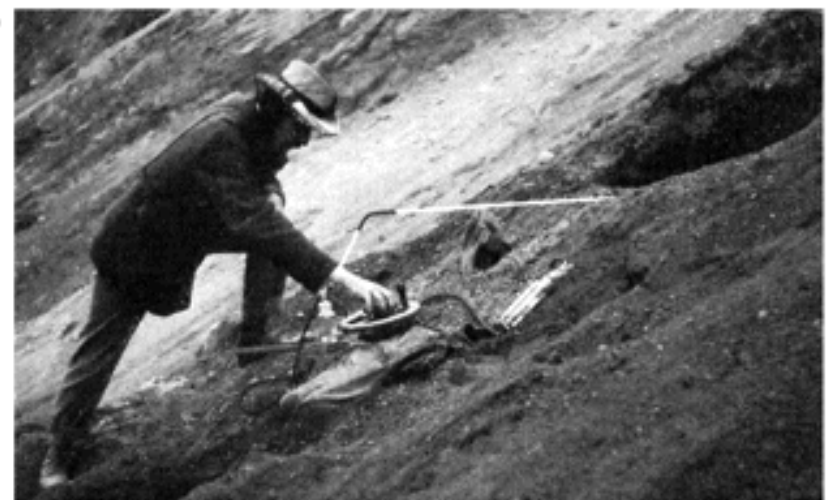

(b)

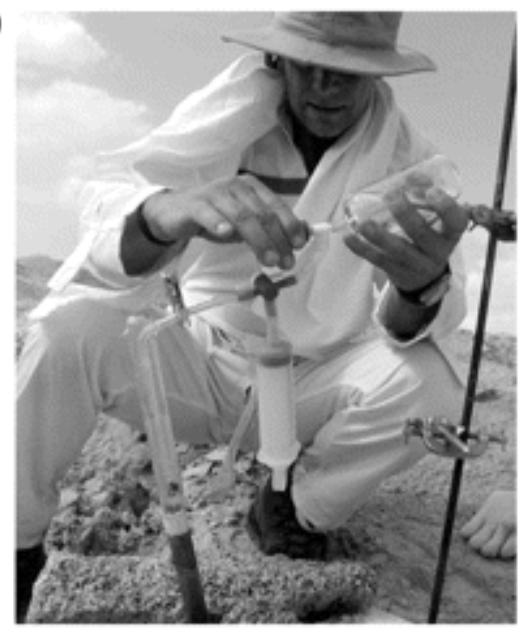

Figure 6. : Sampling volcanic emissions the traditional way: Frank Perret on Vesuvius and Patrick Allard on Erta 'Ale.

Of course, since Perret's time, analytical capabilities have developed tremendously, and this manner of gas collection continues to yield the most comprehensive analyses of the chemical and isotopic composition of volcanic gas emissions. However, such sampling is challenging for sustained geochemical surveillance, especially when fumaroles are inaccessible or levels of volcanic activity preclude safe approach. This section focuses on the principal sampling and sensing methods applied to measurements of sulfur emissions from volcanoes. It introduces direct sampling and sensing apparatus, ground-based or airborne ultraviolet spectroscopy (Correlation Spectrometer and successors), ground-based infrared spectroscopy (Fourier transform spectroscopy), and satellite remote sensing, including the important role of the Total Ozone Mapping Spectrometer, Ozone Monitoring Instrument, Infrared Atmospheric Sounding Interferometer and other ultraviolet and infrared sensors, for measuring the $\mathrm{SO}_{2}$ emissions from major eruptions.

\section{Direct sampling}

Conventional analyses of volcanic gases have been made by collection of samples directly from fumarole vents using evacuated bottles and caustic solutions, and subsequent laboratory analysis (Symonds et al. 1994). The classic "Giggenbach bottle" (Fig. 6b, Giggenbach 1975; Giggenbach and Goguel 1989; Giggenbach and Matsuo 1991; Giggenbach et al. 2001) consists of an evacuated glass or quartz vessel partially filled with $\mathrm{NaOH}$ or, alternatively, ammonia $\left(\mathrm{NH}_{4} \mathrm{OH}\right)$ solution (Sortino et al. 2006). Sampling is carried out by bubbling gas 
through the solution via tubing inserted into the volcanic vent. Hydrogen sulfide and $\mathrm{SO}_{2}$ readily condense according to reactions such as:

$$
\begin{aligned}
& 4 \mathrm{SO}_{2(g)}+7 \mathrm{OH}_{(a q)}^{-}=3 \mathrm{SO}_{4}^{2-}{ }_{(a q)}+\mathrm{HS}_{(a q)}^{-}+3 \mathrm{H}_{2} \mathrm{O}_{(l)} \\
& \mathrm{H}_{2} \mathrm{~S}_{(g)}+\mathrm{OH}_{(a q)}^{-}=\mathrm{HS}_{(a q)}^{-}+\mathrm{H}_{2} \mathrm{O}_{(l)}
\end{aligned}
$$

The aqueous phase species can be analyzed by ion chromatography. The remaining gaseous species collect in the headspace and are usually analyzed by gas chromatography. A reagent such as $\mathrm{Cd}(\mathrm{OH})_{2}$ or $\mathrm{AgNO}_{3}$ can be used to separate $\mathrm{H}_{2} \mathrm{~S}$ (which reacts with $\mathrm{Cd}^{2+}$ to precipitate $\mathrm{CdS}$, or with $\mathrm{Ag}^{+}$to precipitate $\mathrm{Ag}_{2} \mathrm{~S}$ ) for subsequent analysis (after conversion to sulfate) by ion chromatography (Picardi 1982; Montegrossi et al. 2001, 2008; Aiuppa et al. 2005b). Other solid phases, including $\mathrm{S}_{x}$, can be quantified (e.g., by progressively oxidizing them and analyzing the anions by ion chromatography).

Various activated substances such as silica gel have also been used to trap volcanic gas species for subsequent laboratory analysis, e.g., by gas chromatography (Naughton et al. 1963). Base-treated filters and diffusion tubes provide another means to trap acid species, and can be deployed around crater rims and in the vicinity of gas sources (e.g., Allen et al. 2002; Aiuppa et al. 2004; Martin et al. 2010b). These have been used in studies of $\mathrm{SO}_{2}$ plume dispersion and exposure (Allen et al. 2000; Delmelle 2002; Longo et al. 2005; Aiuppa et al. 2007a; Bhugwant et al. 2009) while rainwater collectors and sulfation plates have been used to map and investigate sulfur deposition (Delmelle et al. 2001, 2003; Aiuppa et al. 2006).

Studies of the aerosol phase in volcanic emissions (of which sulfate is often the most abundant component) have been carried out using particle filters. Such filter-based methods have been extended to characterize aerosol size distribution and chemistry (e.g., Mather et al. 2004b; Martin et al. 2008; Ilyinskaya et al. 2010). The volatiles scavenged out of eruption clouds by ash particles, which then sediment to the ground, can also be studied analytically by leaching samples with distilled water (e.g., Edmonds et al. 2003b; Witham et al. 2005)

Although such approaches offer very high sensitivity, measurements can be difficult and often hazardous to obtain, and complications can arise from post-collection reactions. Also, the typical delays in obtaining results (where laboratory analysis is required) can limit their value in volcanic crisis management.

\section{In situ sensing}

One particularly promising approach to volcanic gas surveillance is the application of electrochemical sensors. These sensors contain an electrolyte, which is exposed to ambient air (and the volcanic emissions) by diffusion (with or without the aid of an air pump). The ensuing redox chemistry generates a current that is proportional to the target gas abundance. Their disadvantages include sensor drift and imperfect specificity to target gases. This represents a significant problem because of the cocktail of gases typically found in a volcanic plume; for example, most commercially available $\mathrm{H}_{2} \mathrm{~S}$ sensors are cross-sensitive to $\mathrm{SO}_{2}$ but because they are mass-manufactured for a wide-range of industrial and consumer applications they are cheap. They have been tested in a number of configurations, and appear capable of reliable $\mathrm{SO}_{2}$ and $\mathrm{H}_{2} \mathrm{~S}$ (and other species) measurements (particularly when combined with, for instance, non-dispersive infrared sensors for $\mathrm{CO}_{2}$ measurement; e.g., Aiuppa et al. 2005a; Shinohara 2005; De Vito et al. 2007; Witt et al. 2008; Roberts et al. 2011). An important 
development is that long-term installations (using Wi-Fi or cell-phone networks, or satellite telemetry) are beginning to provide valuable and near-real time insights into the relationships between surface emissions and magmatic processes (e.g., Aiuppa et al. 2007b, 2010).

Another promising field technique established some while ago, though yet to be more widely used in volcanology, is the portable gas chromatograph (Le Guern et al. 1982; Diaz et al. 2002). Its advantage is its sensitivity and the wide range of species that may be quantified, including $\mathrm{H}_{2} \mathrm{~S}$ and $\mathrm{H}_{2}$.

\section{Ultraviolet spectroscopy}

A striking aspect of volcanic emission measurements is the prominence of observations of sulfur dioxide (Oppenheimer 2010). Considering that the most abundant volcanic vapors are water and carbon dioxide and that sulfur species (including hydrogen sulfide) typically account for less than $5 \mathrm{~mol} \%$ of the gases emitted, it is not immediately obvious why sulfur has been such a focus of study. The reasons are the comparative ease with which $\mathrm{SO}_{2}$ can be measured in the atmosphere and because $S$ is a useful tracer of magmatic processes The former aspect is due to its electronic absorption spectrum which provides a strong fingerprint against the ultraviolet background light in the daytime sky. Ultraviolet sensing using the sky as source eliminates one typical problem with optical spectroscopy-the need for precise alignment of the spectrometer with respect to the light source. All that is necessary is to collimate some sky light through a telescope and direct it into the spectrometer.

The particular importance of ultraviolet sensing of volcanic plumes is that it represents the most straightforward means for estimating degassing rates (which are difficult to measure based on point sampling). The flux of $\mathrm{SO}_{2}$ from a vent or crater can be measured by recording the column density of all the $\mathrm{SO}_{2}$ molecules contained in a (generally though not necessarily) vertical section of the whole plume, and computing the product of the integrated column cross section of $\mathrm{SO}_{2}$ and the plume speed. In practice, the plume may be traversed roughly perpendicularly to the wind direction while pointing the spectrometer's telescope up from the ground, or scanned from a fixed position. Thanks to the diffuse sky ultraviolet source, the pointing direction of the telescope is not critical. Acknowledging the significance of gas flux measurements in volcanic hazard assessment, this subsection will review in greater depth the development and application of ultraviolet remote sensing and spectroscopy in volcanology.

\section{The Correlation Spectrometer (COSPEC).}

The first remote sensing instrument to become widely used for volcanic plume monitoring was the Barringer Research "COSPEC", or Correlation Spectrometer (Williams-Jones et al. 2008). The COSPEC was introduced four decades ago to measure industrial $\mathrm{SO}_{2}$ and $\mathrm{NO}_{2}$ sources (Moffat and Millán 1971; Hoff and Millán 1981), but its value for measuring volcanic emissions was quickly recognized (Stoiber and Bratton 1978; Stoiber et al. 1983). Early volcanological interest addressed the question of whether changes in $\mathrm{SO}_{2}$ flux could be associated with magma migration and eruptive style. For instance, Malinconico (1979) reported a positive correlation between increasing $\mathrm{SO}_{2}$ flux and eruptive vigor at Mt. Etna. The Correlation Spectrometer went on to play a prominent monitoring role during many volcanic crises, crucially helping to discriminate magmatic origins of volcanic unrest. Of particular note, COSPEC played a vital role in civil emergency planning during the unrest of Mt. Pinatubo in 1991. As seismic unrest increased two weeks before the magmatic denouement, so did the $\mathrm{SO}_{2}$ flux, supporting the view that a substantial magma body was 
connecting with the surface. This interpretation prompted the civil evacuation credited with saving tens of thousands of lives (Daag et al. 1996).

COSPEC measurements have also been influential in recognizing the importance of magma convection, permeability and gas separation (e.g., Francis et al. 1993; Kazahaya et al. 1994; Oppenheimer et al. 2002a). Furthermore, as COSPEC observations were made at more and more volcanoes around the world, the compiled data yielded another important result, namely the first estimates of the global emission of volcanic $\mathrm{SO}_{2}$ (discussed in a later section).

The COSPEC design goal was to build a system capable of minimizing all "noise" (including those due to light absorption and scattering by other atmospheric constituents) in order to measure a single species (e.g., $\mathrm{SO}_{2}$ ). The result was an instrument that yields an estimate of the quantity of $\mathrm{SO}_{2}$ in the field of view (measured, for instance, in units of mass per unit area of the atmospheric column). While this greatly simplified data retrieval and processing, it made it difficult to assess potential errors arising from wavelength shifts, light scattering and solar-elevation effects, thermal and mechanical distortions, and so on. Also, the COSPEC response depended on the correlation mask used and the abundance of gases present. An alternative approach is to measure wide-band spectra with sufficient spectral resolution to be able to model trace-gas abundances. With the COSPEC long out of production now, a new generation of ultraviolet spectrometers has come to the fore in the realm of volcano surveillance (Oppenheimer 2010).

\section{Ultraviolet Differential Optical Absorption Spectroscopy (DOAS).}

The common approach to recording an ultraviolet spectrum is use of a diffraction grating to disperse the light received by an optical telescope coupled to the spectrometer. Spectra are typically collected using a CCD detector array onto which the dispersed light is focused. Analysis of the spectra and determination of trace-gas abundances are widely carried out with a methodology known as differential optical absorption spectroscopy, or DOAS (Platt and Stutz 2008). A key approach of DOAS is the removal of fluctuations in the recorded spectrum that result from molecular and aerosol scattering in the atmosphere. Because their spectral dependence is of lower frequency than that associated with the electronic structure of absorbing molecules, appropriate signal processing yields absorption spectra suitable for modeling. Another trick widely used in DOAS practice is to obtain atmospheric spectra with and without the emissions of interest present. In the case of volcanic emissions, this can be achieved by collecting "background" or "clear sky" spectra from either side of the plume.

All the plume spectra are then divided by the out-of-plume background spectrum. This reduces interferences caused by background atmospheric absorption and the solar spectral structure (Fraunhofer lines). Specific gases can be identified by their characteristic absorption spectra, and their abundances derived from the strength of the absorption, following the BeerLambert formula:

\section{$I(\lambda)=I_{0}(\lambda) \exp (-\sigma(\lambda) N L)$}

where $I(\lambda)$ is the observed intensity of radiation at wavelength $\lambda, I_{0}(\lambda)$ is the original intensity of radiation before interaction with the sample, $\sigma(\lambda)$ is the absorption cross section of the absorbing molecule at wavelength $\lambda$, and $N$ is the mean concentration of the species over the path-length $L$ of the sample. In general practice, the logarithm of the ratio spectrum is computed, and then $\mathrm{SO}_{2}$ (and other gas species) amounts can be calculated by scaling reference spectra of the gases of interest (obtained 
via laboratory experiments: Fig. 7) until they match the observed spectrum. The scaling factors thus identified, along with the known abundances for the reference spectra, determine the gas column amounts in the plume.

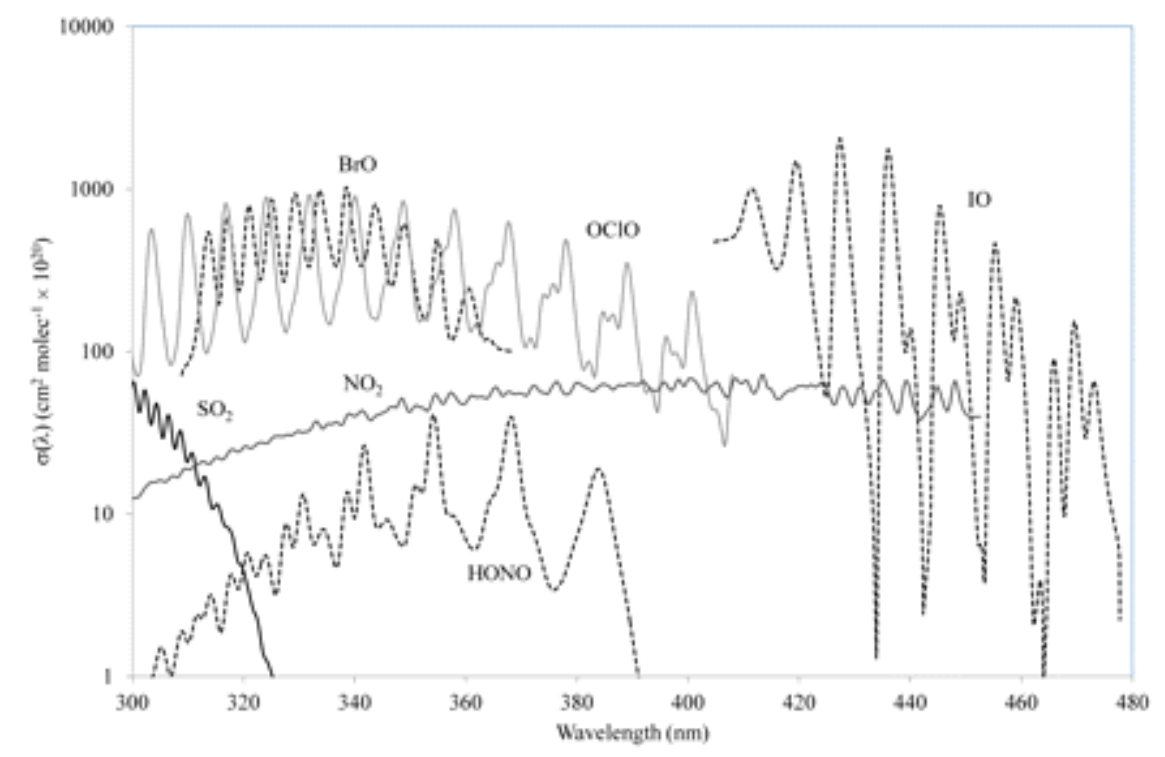

Figure 7. : Plots of absorption cross sections in the ultraviolet and visible regions of the spectrum for several gases: $\mathrm{SO}_{2}, \mathrm{NO}_{2}, \mathrm{BrO}, \mathrm{HONO}, \mathrm{IO}$ and $\mathrm{OClO}$ (convolved with a Gaussian function of $1.21 \mathrm{~nm}$ full-width-at-half-maximum). Data courtesy of Vitchko Tsanev (University of Cambridge).

The first volcanological DOAS observations were made in 1992 from a scientific vessel that cruised the Mediterranean downwind of Etna, Stromboli and Vulcano (Edner et al. 1994; Weibring et al. 1998, 2002). A bulky ultraviolet spectrometer was employed, and it was operated alongside a COSPEC and a lidar (light detection and ranging) system that was also capable of $\mathrm{SO}_{2}$ measurements (see below). At that time, COSPEC represented the state of the art for remote geochemical surveillance of volcanoes, and its pre-eminence was not challenged by the expensive and more operationally complex DOAS and laser-based instruments. But this picture changed in early in the 2000s owing to the commercial availability of ultraviolet spectrometers built around low-cost CCD detectors and massproduced optical benches. They were cheaper, smaller and less power consumptive than anything else on the market and could be controlled via USB connection to a portable computer.

The first volcanological measurements with this new generation of spectrometer were made at Masaya (Nicaragua) in 2001 (McGonigle et al. 2002; Galle et al. 2003). Several competing spectrometers are now available (Kantzas et al. 2009), and there has been tremendous innovation in the application of the new technology as volcanologists have been quick to seize on the potential of such cheap, adaptable and capable devices. One of the first tasks required was to confirm good agreement between DOAS-based estimates of $\mathrm{SO}_{2}$ emissions and those obtained by COSPEC. This was particularly important for volcano observatories switching to the new technology (Elias et al. 2006). The next development was the more imaginative deployment of the miniature ultraviolet spectrometers (Fig. 8). Observational platforms for traverse-style measurements have included pedestrians (McGonigle et al. 2002; Mori et al. 
2006), fixed-wing aircraft, helicopters and ultra-light aircraft (Grutter et al. 2008) and a remote-controlled helicopter (McGonigle et al. 2008).
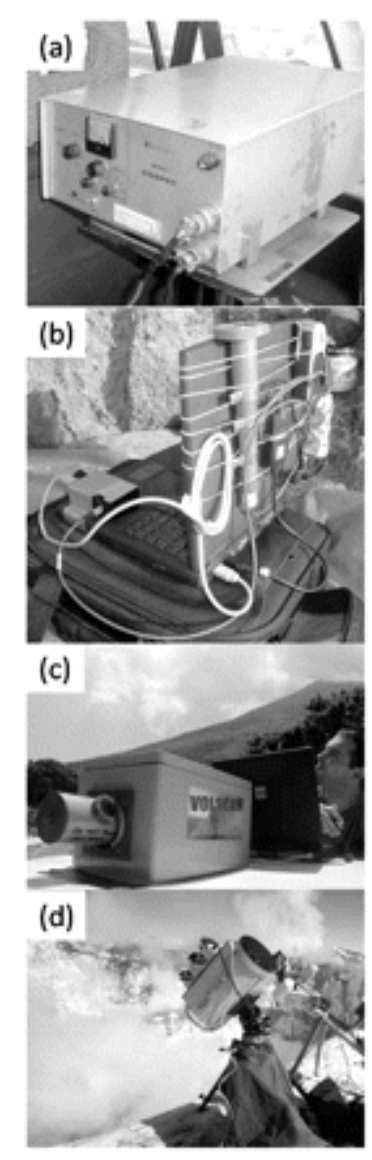

Figure 8. : Photographs of portable ultraviolet and infrared sensing systems for plume measurements: (a) INGV-Catania's Mini-COSPEC in operation on Mt. Etna; (b) compact ultraviolet spectrometer set up for walking traverses on Erta 'Ale volcano (the spectrometer is near the laptop's keyboard; (c) one of the first scanning systems for ultraviolet sensing of $\mathrm{SO}_{2}$ emissions, in use on Stromboli; (d) FTIR spectrometer during measurements on Erebus volcano, Antarctica.

With respect to gas-flux measurements, considerable attention has to be given to the estimation of plume transport speeds. It is widely acknowledged that uncertainty in plume speed (typically a few tens of \%) dominates errors in measurements of $\mathrm{SO}_{2}$ and other gas fluxes. A consistent approach to constraining plume speed is therefore essential. Absorptioncorrelation methods using spatially distributed instruments (McGonigle et al. 2005; WilliamsJones et al. 2006) or a multi-beam instrument (e.g., Johansson et al. 2009b; Boichu et al. 2010) are arguably the most rigorous means to record plume velocity accurately (see below).

By virtue of recording spectra, broadband UV spectroscopy has the capability of detecting multiple gas species. Measurements of $\mathrm{H}_{2} \mathrm{~S} / \mathrm{SO}_{2}$ ratios have been accomplished at Vulcano, Italy, using a compact ultraviolet spectrometer and an ultraviolet lamp (O'Dwyer et al. 2003; Aiuppa et al. 2005a). The use of an artificial source along with comparatively short pathlengths is required because the $\mathrm{H}_{2} \mathrm{~S}$-absorption feature is in the shorter-wavelength region of the ultraviolet spectrum that is not transmitted over long paths in the atmosphere. Another 
species that can be measured by DOAS in the ultraviolet region (but at longer wavelengths) is $\mathrm{BrO}$. This species is of significance for its impact on atmospheric ozone and measured $\mathrm{SO}_{2} / \mathrm{BrO}$ ratios combined with $\mathrm{SO}_{2}$ flux estimates for a number of volcanic plumes worldwide are beginning to provide a picture of the regional and global importance of volcanogenic reactive bromine emissions (Oppenheimer et al. 2006; Bobrowski and Platt 2007; Bobrowski et al. 2007; Bani et al. 2009; Boichu et al. 2011).

\section{Operational surveillance.}

The sustained surveillance carried out by volcano observatories demands a high degree of automation of monitoring systems. This saves the time and expense of repeated fieldwork; enables networks of sensors to be developed; protects staff from prolonged exposure in hazardous areas; and permits more time to be spent on data analysis, synthesis and interpretation. The low power requirements and cost of the new generation of ultraviolet spectrometers have spurred development of autonomous $\mathrm{SO}_{2}$ monitoring stations. However, to measure $\mathrm{SO}_{2}$-degassing rates, fixed installations must mimic the traverse method of flux estimation by scanning the sky sequentially in a plane that intersects the plume. This can be readily achieved by rotating the field of view of the spectrometer around the sky by use of a stepper motor to which a plane mirror is attached. Combined with a telemetry system and powered by solar energy, such a station may operate autonomously, transmitting spectra back to the volcano observatory. The first scanner development applied to volcanic-plume measurements was reported by McGonigle et al. (2002, 2003). This was a portable system designed for rapid, campaign installation, but it was soon superseded by Montserrat Volcano Observatory's autonomous ultraviolet DOAS stations (Edmonds et al. 2003a). Subsequently, scanner networks were installed at Tungurahua volcano, Ecuador (Arellano et al. 2008), Stromboli (Burton et al. 2009) and Etna (Salerno et al. 2009a,b). Two European projects (DORSIVA and NOVAC; www.novac-project.eu/) have taken this concept even further through the development of a scanning system that has now been installed at seventeen volcanoes worldwide (Galle et al. 2010).

One complication in obtaining a flux measurement with a scanning instrument is that uncertainty in the plume height corresponds directly to uncertainty in the flux estimation. Since the measurements are made radially within a plane that intersects the plume, the measurement from a single instrument cannot discriminate between a high, wide plume and a low, narrow plume (with correspondingly lower $\mathrm{SO}_{2}$ flux), even if the two have identical $\mathrm{SO}_{2}$ mixing ratios and thicknesses. Thus, plume height must be determined accurately if the scanner is to yield a reliable measurement of flux. This can be achieved crudely through simple scaling between wind speed and plume height, through more sophisticated dispersion modeling, or, ideally, from the observations themselves. Arguably the most robust procedure is the tomographic reconstruction of the plume's $\mathrm{SO}_{2}$ cross section, demonstrated by Wright et al. (2008), Kazahaya et al. (2008) and Johansson et al. (2009a). Nevertheless, tomographic approaches rely on assumptions about distribution of $\mathrm{SO}_{2}$ in the cross section, and are computationally costly to implement.

A further important benefit of scanning systems is their capability for rapid flux measurements. In practice, plume scans may be made within a few minutes, providing a high time resolution. This can reveal rapid variability in source emissions, which might, for instance, relate to fluctuating magma flow to the surface. When two-dimensional CCD detectors are used (one dimension representing the spectral information), it is possible to build an image with a scanning system, yielding valuable information on gas distribution within a 
plume (e.g., Louban et al. 2009). But even higher time resolution is possible with ultraviolet cameras (the use of which, however, entails sacrificing much spectral information) since an entire plume can be captured instantaneously with the imposition of filters to provide the spectral contrast needed for $\mathrm{SO}_{2}$ measurement (Mori and Burton 2006, 2009; Bluth et al. 2007; Yamamoto et al. 2008; Dalton et al. 2010; Kantzas et al. 2010).

A variation on this approach is the use of telescopes with distorted optical fields of view. Boichu et al. (2010) designed a device with two spectrometers attached to telescopes with cylindrical lenses. The two fields of view were parallel but offset by a small angle, achieved with a goniometer. The advantage of the system is that the stretched field of view records all the $\mathrm{SO}_{2}$ rising out of the crater simultaneously (without recourse to scanning). Further, the angular offset between the two telescopes permits calculation of the plume speed by correlating the time series of $\mathrm{SO}_{2}$ obtained from the two spectrometers. This approach can provide accurate $\mathrm{SO}_{2}$ flux measurements at very high time resolution depending on the correlation length needed to resolve plume speed and could, in principle, provide a real-time $\mathrm{SO}_{2}$ flux meter.

Reliable measurements are the cornerstone of volcano monitoring and are vital for effective hazard evaluation. These new spectroscopic approaches, which constrain plume speed and height, are particularly suited to delivering accurate, high time-resolution, $\mathrm{SO}_{2}$ flux measurements. Work remains to be done to establish the extent to which atmospheric radiative transfer effects, such as multiple scattering in dense plumes and in-scattering of light in front of plumes when observed from long distances, affect measurements (Kern et al. 2010), but undoubtedly, $\mathrm{SO}_{2}$ observations will increasingly contribute to routine observatory work and to a deeper understanding of magma degassing and volcanic activity.

\section{Broad-band infrared spectroscopy}

Infrared absorption spectroscopy is widely used in the analytical sciences for measuring the rotational structure of vibrational spectral bands. Naughton et al. (1969) appear to be the first to have applied the technique in an open-path configuration to field measurement of volcanic gas emissions. They were able to measure $\mathrm{SO}_{2}, \mathrm{CO}_{2}$ and $\mathrm{H}_{2} \mathrm{O}$ at Kilauea using a fire fountain as the infrared source. However, it was not until the first half of the 1990s that field portable Fourier transform infrared (FTIR) spectrometers became more widely used in volcanology.

FTIR spectrometers are based on Michelson interferometers. Collimated light from an infrared source is admitted to the instrument and divided into two beams using an optical beam-splitter, which also recombines these beams after they are reflected at mirrors. One of the mirrors is translated back and forth along the optical axis, introducing a variable path difference between the two beams, resulting in a time-variable signal from the single broadband detector due to interference of recombined beams. Application of an inverse Fourier transform to the temporal signal yields absorption spectra, from which the column amounts of volcanic gases present in the optical path can be retrieved (following the BeerLambert law; Eqn. 15). A range of infrared light sources: direct sunlight, fire fountains, lava lakes, hot rocks, and infrared lamps have been used in volcanological work highlighting the flexibility of the approach to adapt to the circumstances of activity, access and terrain. Love et al. $(1998,2000)$ have shown it is also possible to measure volcanic gases emitting infrared radiation against a cold sky background. At Popocatépetl volcano, Mexico, Love et al. (1998) observed a steady increase in $\mathrm{SiF}_{4} / \mathrm{SO}_{2}$ ratio prior to an eruption in February 1997, followed by a tenfold decrease within a few hours. These results suggested a cooling of the gas prior to 
the eruption, attributed to adiabatic gas expansion on release of a solidified magma plug in the conduit.

The first FTIR spectroscopy of volcanic emissions was carried out in 1991 at Asama volcano, Japan (Notsu et al. 1993), by a team that has subsequently reported measurements at Unzen, Japan ( $\mathrm{SO}_{2}$ and $\mathrm{HCl}$; Mori et al. 1993); Aso, Japan (CO, OCS, $\mathrm{CO}_{2}, \mathrm{SO}_{2}$ and $\mathrm{HCl}$; Mori and Notsu 1997); and Vulcano, Italy ( $\mathrm{SO}_{2}$ and $\mathrm{HCl}$; Mori et al. 1995). Benefits of open-path infrared spectroscopy include its adaptability to diverse field circumstances (Francis et al. 1995, 1998; Oppenheimer et al. 1998a) and the ability to detect and measure abundances of several gases of interest (including $\mathrm{H}_{2} \mathrm{O}, \mathrm{SO}_{2}, \mathrm{HCl}, \mathrm{HF}, \mathrm{CO}_{2}, \mathrm{CO}, \mathrm{SiF}_{4}$, and $\mathrm{OCS}$ ).

Measurements of the relative abundance for different gases can be made with a temporal sampling rate of about $1 \mathrm{~Hz}$ (Fig. 9). Data can even be collected during more vigorous eruptive episodes. This provides significant insights into the dynamics of magma transport and degassing of magma (e.g., Allard et al. 2005; Burton et al. 2007b; Oppenheimer et al. 2009, 2011).

(a)

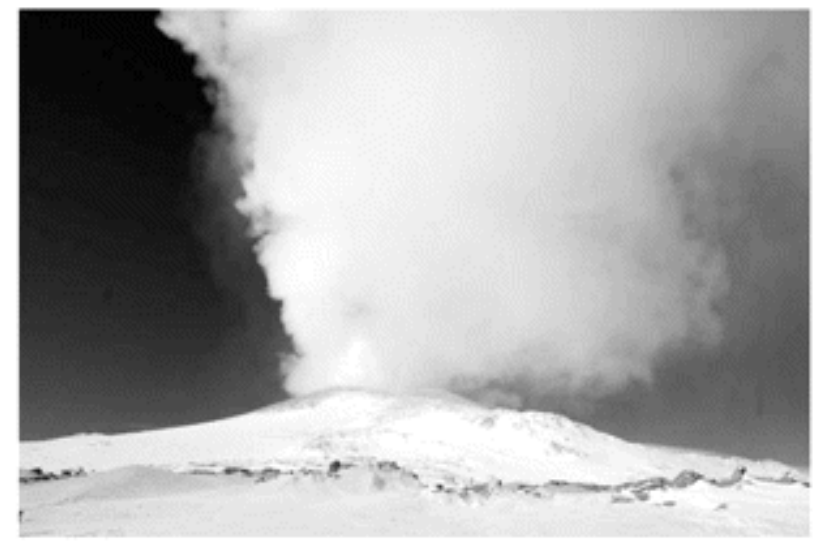

(b)

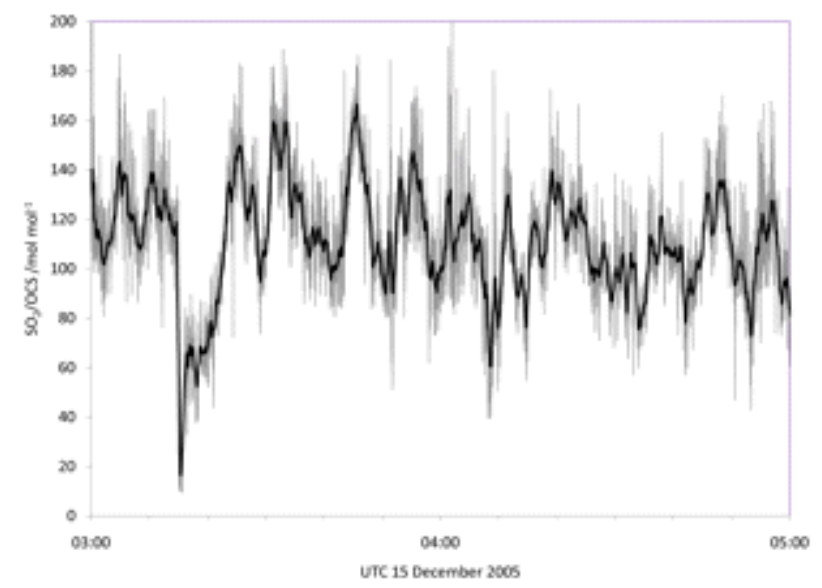

Figure 9. : (a) Photograph of Erebus volcano showing strong degassing from the anorthoclase phonolite lava lake within the summit crater; (b) plot of molar ratio of $\mathrm{SO}_{2} / \mathrm{OCS}$ retrieved from absorption spectra of the plume collected with a FTIR spectrometer sited at the crater rim and viewing the lava lake (the infrared source). Raw interferograms were collected with a time-step of $\sim 1 \mathrm{~s}$. Note the gas signature of an explosion 03:15 UT (much lower $\mathrm{SO}_{2} / \mathrm{OCS}$ ) and the quasi-periodic variation in the gas ratio (period around 10-20 min), which is thought to reflect pulsatory magma supply to the lake (Oppenheimer et al. 2009).

Although $\mathrm{H}_{2} \mathrm{~S}$ has a well-characterized infrared spectrum, its detection in a volcanic plume by infrared absorption spectroscopy does not appear to have been reported. The accessible bands are relatively 
weak and overlap with regions prone to stronger signals from $\mathrm{H}_{2} \mathrm{O}$ and $\mathrm{CO}_{2}$. Nor can $\mathrm{S}_{2}\left(\right.$ or $\left.\mathrm{H}_{2}\right)$ be measured by conventional infrared spectroscopic methods since they are homonuclear and therefore their vibrational modes are not infrared active. This is unfortunate, since measurement of combinations of oxidized and reduced species enables modeling of the degree of equilibrium represented by the volcanic emission. However, CO and OCS can be measured under suitable conditions, and their relative abundances probed according to the following redox equation:

$3 \mathrm{CO}+\mathrm{SO}_{2}=2 \mathrm{CO}_{2}+\mathrm{OCS}$

Factors that affect the balance of reactants and products include oxidizing capacity of the melt, temperature and pressure. Infrared spectroscopy has succeeded in measuring these four species at a few volcanoes including Aso (Mori and Notsu 1997, 2008), Stromboli (Burton et al. 2007b), Nyiragongo (Sawyer et al. 2008b) and Erebus (Oppenheimer and Kyle 2008).

\section{Laser spectroscopy}

To date, the most commonly applied laser technique for volcanic plume measurements is lidar, in which a pulsed laser beam is directed towards the plume. Recording the temporally varying intensity of backscattered light provides information about the atmospheric composition as a function of propagation distance along the beam's path. Lidar has been used to measure concentrations and fluxes (via traverses) of sulfate aerosol (Casadevall et al. 1984; Porter et al. 2002), as well as ash. Parallel gas sampling and aerosol measurements can enable estimation of gas to particle conversion rates (e.g., for $\mathrm{SO}_{2}$ to $\mathrm{SO}_{4}{ }^{2-}$; Stith et al. 1978; Radke 1982; Rose et al. 1986).

A variation on lidar known as differential absorption lidar (DIAL) involves rapid switching the frequency of laser pulses on- and off-resonance of an absorption feature of the gas of interest. By ratioing the lidar signals (returned signal versus height) obtained at the two wavelengths and applying the Beer-Lambert law (Eqn. 15), range-resolved gas mixing ratios may be derived revealing detailed plume structure, in contrast to the column amounts obtained from FTIR, COSPEC and DOAS. The technique has been applied to the Southern Italian volcanoes using ultraviolet lasers (Edner et al. 1994; Weibring et al. 1998, 2002), in parallel with COSPEC and an ultraviolet spectrometer, revealing $\mathrm{SO}_{2}$ column amounts up to $50 \%$ higher in the former case as a consequence of scattering-induced errors in the passive techniques (Kern et al. 2010). However, this DIAL apparatus was costly, heavy and bulky. Whilst DIAL offers unique capabilities for volcanology, it requires further innovation in order to become a suitable tool for routine observatory use.

Alternative sensing strategies using near- and mid-infrared diode-based lasers (Gianfrani et al. 2000; Richter et al. 2002; Rocco et al. 2004; Kassi et al. 2006) have been evaluated by monitoring the laser beam's absorption following numerous transits of a multi-pass cell, into which the volcanic gas sample is pumped. Thanks to very narrow spectral line-widths, lasers can make sensitive measurements of isotopic abundances. They can even resolve isotopomers that would be very difficult to discriminate by isotope ratio mass spectrometry. Richter et al. (2002) and Weidmann et al. (2003) have described a mid-infrared laser system capable of measuring all isotopes of $\mathrm{CO}_{2}$, while Gianfrani et al. (2003) have tested a diode laser spectrometer able to measure water isotopes in the near-infrared. Castrillo et al. (2004) measured ${ }^{13} \mathrm{C} /{ }^{12} \mathrm{C}$ in the field with a diode-based laser spectrometer. Christensen et al. (2007) 
described a tunable infrared laser spectrometer capable of measuring the isotopic composition of $\mathrm{SO}_{2}$.

\section{Satellite remote sensing}

The larger releases of volcanic volatiles to the atmosphere defy synoptic measurements from the ground. This is where space-borne Earth observation methods play a preeminent role. Indeed, major advances in our understanding of explosive volcanism and its impact on the atmosphere and climate have been achieved thanks to satellite observations. Again, sulfur dioxide is the most readily measured species - its abundance in volcanic clouds has been measured using space-borne sensors operating in the ultraviolet (electronic structure), infrared (roto-vibrational structure) and microwave (rotational structure) regions of the spectrum. The earliest measurements were made by the ultraviolet-sensing Total Ozone Mapping Spectrometer (TOMS), which was operational (in various guises and with data gaps) between 1978 and 2006 (Krueger 1983; Krueger et al. 1995, 2008; Carn et al. 2003). It detected many larger silicic and intermediate composition explosive eruptions, and some mafic eruptions, notably those from Nyiragongo and Nyamuragira in the Great Lakes region of central Africa (Carn et al. 2003). TOMS along with the infrared TOVS (TIROS Optical Vertical Sounder) provided early estimates of the initial sulfur yield to the stratosphere of the $1991 \mathrm{Mt}$. Pinatubo eruption (around 9 \pm 2 Tg of S; Guo et al. 2004) and other instruments, including NASA's Microwave Limb Sounder (MLS), were able to track the $\mathrm{SO}_{2}$ clouds as they were depleted over the following weeks (Read et al. 1993). As discussed earlier, these observations provided crucial data on $\mathrm{SO}_{2}$ yields for comparison with estimates derived from petrological arguments.

More recently-launched space-borne ultraviolet instruments have significantly improved capabilities for measuring volcanic $\mathrm{SO}_{2}$ emissions. In particular, wider wavelength coverage has lowered detection limits enabling measurements of lesser volcanic clouds. These devices include the Ozone Monitoring Instrument (OMI: Yang et al. 2007, 2009a,OMI: Yang et al. b; Carn et al. 2009; Krueger et al. 2009), Global Ozone Monitoring Experiment-2 (GOME-2: Heue et al. 2010) and the SCanning Imaging Absorption SpectroMeter for Atmospheric CHartographY (SCIAMACHY: Lee et al. 2009a,b). Several space-borne infrared sensors including the Infrared Atmospheric Sounding Interferometer (IASI), the Advanced Spaceborne Thermal Emission and Reflection Radiometer (ASTER) and the Atmospheric InfraRed Sounder (AIRS) can also quantify volcanic $\mathrm{SO}_{2}$ emissions (e.g., Prata and Bernardo 2007; Prata and Kerkmann 2007; Clerbaux et al. 2008; Doutriaux-Boucher and Dubuisson 2008; Eckhardt et al. 2008; Corradini et al. 2009; Campion et al. 2010) and in some cases, simultaneously, the $\mathrm{H}_{2} \mathrm{SO}_{4}$ aerosol abundance (Watson et al. 2004; Karagulian et al. 2010).

\section{INTERPRETATION OF SULFUR-EMISSION DATA}

Time-series of gas flux, chemical and isotopic measurements can be interpreted with respect to magma and volcano behavior, and the interrelationships between degassing, eruptive character, and other geophysical and geodetic parameters (Table 1). Gas geochemistry therefore plays an important role in volcanic hazard assessment. Temporal changes in gas chemistry and flux, in particular, are widely regarded as diagnostic of future volcanic activity, and many volcano observatories worldwide measure plume and fumarole emissions as part of their monitoring efforts. The basic tasks are to identify volatile sources, magma-hydrothermal system interactions, the dynamics of degassing, and changes in these through time. However, interpretation of the observations is highly challenging because of the multiple intensive 
parameters that control magmatic volatile content (mantle melting, slab contributions, wallrock assimilation, etc.), exsolution and gas separation of different volatile species from magma, and the subsequent chemical and physical interactions of the exsolved fluids, for example, with crustal rocks and hydrothermal fluids, as they ascend to the surface

(Giggenbach 1996; Oppenheimer 2003).

\section{Proportions of sulfur species}

In general terms, the relative proportions of sulfur species in a volcanic emission are dictated by temperature-, pressure- and redox-controlled partition coefficients between vapor and melt, the mixing or mingling of different magma sources, the dynamics of degassing, and interactions with crustal rocks and magmatic-hydrothermal fluids (e.g., Giggenbach 1987, 1996, 1997; Gerlach and Nordlie 1975; Gerlach 1993; Symonds et al. 1994). Pertinent redox equilibria affecting volcanic gas composition include:

$\mathrm{SO}_{2}+3 \mathrm{H}_{2}=\mathrm{H}_{2} \mathrm{~S}+2 \mathrm{H}_{2} \mathrm{O}$

for which:

$\log \left(\frac{\mathrm{SO}_{2}}{\mathrm{H}_{2} \mathrm{~S}}\right)=\log K_{1}-3 R_{H^{-}}-\log \left(f_{\text {tot }} \mathrm{X}_{\mathrm{H}_{2} \mathrm{O}}\right)$

The $\mathrm{SO}_{2} / \mathrm{H}_{2} \mathrm{~S}$ ratio thus increases with $f_{\mathrm{O} 2}$ (since $-\mathrm{R}_{H}=\log \left(\mathrm{H}_{2} \mathrm{O} / \mathrm{H}_{2}\right)$, decreasing total pressure $\left(f_{\text {tot }}\right)$ and decreasing mole fraction of $\mathrm{H}_{2} \mathrm{O}\left(X_{\mathrm{H} 2 \mathrm{O}}\right)$. Further, since the forward reaction of Equation (17) is endothermic, the equilibrium constant $\left(\mathrm{K}_{1}\right)$ increases with temperature (Giggenbach 1987; Martin et al. 2009). Also relevant is the following equation:

$\mathrm{FeO}_{(\text {melt })}+\frac{1}{2} \mathrm{~S}_{2}=\mathrm{FeS} S_{(\text {melt } / \text { solid })}+\frac{1}{2} \mathrm{O}_{2}$

This is most likely to represent a major gas redox buffer because of the comparable abundances of the two S-bearing gas species and its strong pressure dependence. The complexity of sulfur degassing in part reflects the multiple valences of sulfur and variety of sulfur species. In magmas, the key species are $\mathrm{S}^{2-}$ and $\mathrm{SO}_{4}{ }^{2-}$ in the melt and $\mathrm{H}_{2} \mathrm{~S}$ and $\mathrm{SO}_{2}$ in the gas phase (Baker and Moretti 2011, this volume; Webster and Botcharnikov 2011, this volume). Surface emissions may also include $\mathrm{S}_{2}, \mathrm{OCS}, \mathrm{SO}_{3}, \mathrm{H}_{2} \mathrm{SO}_{4}, \mathrm{SO}$, HS, metal sulfides and sulfates and so on, in a combination of gaseous, aqueous or other solid/liquid phases.

At low temperatures where sulfur can condense, the following generalized reactions become important:

$$
\begin{aligned}
& \mathrm{SO}_{2}+2 \mathrm{H}_{2} \mathrm{~S}=\frac{3}{x} \mathrm{~S}_{x}(\text { solid } / \text { liquid })+2 \mathrm{H}_{2} \mathrm{O} \\
& \mathrm{SO}_{2}+\mathrm{H}_{2} \mathrm{~S}+\mathrm{H}_{2}=\frac{2}{x} \mathrm{~S}_{x}(\text { solid } / \text { liquid })+2 \mathrm{H}_{2} \mathrm{O}
\end{aligned}
$$

In crater-lake environments, polythionates $\left(\mathrm{S}_{x} \mathrm{O}_{6}{ }^{2-}\right.$, where $\left.x=4-15\right)$ may also form according to activity of subaqueous fumaroles (Takano et al. 1997):

$$
\begin{aligned}
& \mathrm{H}_{2} \mathrm{~S}+3 \mathrm{SO}_{2}=\mathrm{S}_{4} \mathrm{O}_{6}^{2-}+2 \mathrm{H}^{+} \\
& \mathrm{S}_{x} \mathrm{O}_{6}^{2-}+\mathrm{HSO}_{3}^{-}=\mathrm{S}_{x-1} \mathrm{O}_{6}^{2-}+\mathrm{S}_{2} \mathrm{O}_{3}^{2-}+\mathrm{H}^{+}
\end{aligned}
$$


$\mathrm{S}_{(\text {liquid })}^{0}+\mathrm{HSO}_{3}^{-} \rightarrow \mathrm{S}_{2} \mathrm{O}_{3}^{2-}+H^{+}$

Although thermodynamical codes have been developed to restore observed analyses of gas composition to equilibrium compositions (e.g., Gerlach 1993; Symonds et al. 1994), unraveling these complex and highly non-linear processes from a patchy record of surface observations, and identifying precise magmatic and hydrothermal processes, remain real challenges (Burgisser and Scaillet 2007; Burgisser et al. 2008).

\section{Sulfur fluxes}

Some of the volcanoes with the most sustained $\mathrm{SO}_{2}$ flux monitoring include the basaltic systems of Etna (Caltabiano et al. 1994; Salerno et al. 2009), Kilauea (Sutton et al. 2001, 2003) and Miyakejima (Kazahaya et al. 2004, 2008). For this long-term monitoring, the $\mathrm{SO}_{2}$ flux datasets have contributed to inferences on lava effusion rates, the fluid dynamics of magma conduits and in particular understanding of the decoupling of gas and melt on magma ascent. At Miyakejima, regular COSPEC observations reveal remarkable and ongoing decadal-scale decay in $\mathrm{SO}_{2}$ flux since a caldera-forming episode in 2000

(http://staff.aist.go.jp/kazahaya-k/SO2average.htm).

However, even a casual perusal of the literature on gas geochemical monitoring of intermediate to silicic volcanoes will reveal conflicting interpretations of ostensibly similar observations - for instance, decreasing $\mathrm{SO}_{2}$ fluxes have been ascribed to: (i) depletion of volatiles in a magma body, and (ii) decreased permeability (e.g., due to sealing of bubble networks by hydrothermal precipitation). Process (i) might be taken to indicate diminished eruption likelihood, while (ii) might act to pressurize the magma and increase the chance of eruption (e.g., Stix et al. 1993; Fischer et al. 1994; Watson et al. 2000; Edmonds et al. 2003c). Thus the same observation can be interpreted in different ways with contradictory hazard implications. Scientists at observatories often have a better feel for how to interpret changes based on expertise gained from extended monitoring a particular volcano.

Nevertheless, high $\mathrm{SO}_{2}$ fluxes remain a reliable indicator of the presence of magma during episodes of unrest at volcanoes, and help to discriminate between magmatic, and tectonic or hydrothermal causes of unrest. In particular, COSPEC measurements are generally recognized as having contributed significantly to hazard assessment prior to the 1991 eruption of Mt. Pinatubo (Daag et al. 1996; Hoff 1992). Immediately prior to the eruption the measured $\mathrm{SO}_{2}$ flux increased by an order of magnitude over two weeks, mirroring seismic unrest. These observations were interpreted as evidence of shallow intrusion of magma, suggesting increased likelihood of an impending eruption.

Observations of elevated $\mathrm{SO}_{2}$ emission rates (exceeding $500 \mathrm{Mg} \mathrm{d}^{-1}$ ) at Soufrière Hills Volcano (Montserrat) also pointed to sustained magmatic unrest during a hiatus in dome growth in 1998-1999, at a time when geodetic and seismic anomalies were diminished (Oppenheimer et al. 2002a). They also provided evidence for significant permeability in the magma plumbing system to permit sulfur sourced from mafic magma at depth to reach the surface. Observations at other intermediate and silicic volcanoes have revealed decreasing post-effusive $\mathrm{SO}_{2}$ emission rates, including Augustine (Symonds et al. 1990), Redoubt (Casadevall et al. 1994) and Galeras (Zapata et al. 1997). At Mt. St. Helens, both C and S contents of magmatic gases decreased through time following the 1980 Plinian eruption (Gerlach and Casadevall 1986), in parallel with decreasing $\mathrm{SO}_{2}$ emission rate (Swanson et al. 1983; McGee 1992). These indications, along with observed decreases in eruption rate, have 
been interpreted as evidence for exhausted magma supply at depth. Elsewhere, measurements of $\mathrm{SO}_{2}$ flux combined with geochemical indices such as the $\mathrm{C} / \mathrm{S}$ ratio in fumarole or plume gases have yielded insights into magma-hydrothermal processes, with implications for understanding and forecasting phreatic and phreatomagmatic eruptions (e.g., at Ruapheu volcano, New Zealand: Werner et al. 2008; Christenson et al. 2010).

The new networks of ground-based ultraviolet spectrometers discussed above are now highlighting short-term variability in $\mathrm{SO}_{2}$ emission rates. At Soufrière Hills volcano, $\mathrm{SO}_{2}$ flux increases occur following rockfalls and during episodes of seismic tremor, consistent with release of pockets of gas from the dome and uppermost region of the conduit (Edmonds et al. 2003a). Observations made with an ultraviolet camera system enabled Mori and Burton (2009) to determine the mass of $\mathrm{SO}_{2}$ released by individual explosions at Stromboli. At Erebus volcano, measurements with a dual-field of view ultraviolet spectrometer system revealed a cyclic degassing thought to be related to episodic arrival of bubbly magma in the volcano's lava lake (Oppenheimer et al. 2009; Boichu et al. 2010).

\section{Sulfur isotopes}

Isotopic signatures can be of great value in discriminating mantle, crustal and hydrothermal contributions to volcanic fluids (Luhr and Logan 2002); in investigation of degassing processes, for example, open- vs. closed-system mechanisms (Métrich and Mandeville 2010); and in understanding the atmospheric transport of volcanic clouds (Savarino et al. 2003a,b). The extent of fractionation during degassing itself is influenced by temperature and the speciation of sulfur in melt and gas phases, and hence redox conditions (Mandeville et al. 2009; de Moor et al. 2010). The four stable isotopes of sulfur can be used to identify contributions of magmatic volatiles, assuming that isotopic compositions of surface reservoirs are constrained (See summary of Marini et al. 2011, this volume). For example, $\delta^{34} \mathrm{~S}_{\mathrm{SO} 2}$ measurements of gas samples collected from the lava lake of Erta 'Ale volcano (Ethiopia) and Asal Rift (Djibuti) indicated the mantle origin of emitted sulfur $\left(\delta^{34} \mathrm{~S}\right.$ between -5 and $1 \%$; Allard et al. 1977; Allard 1979, 1981), compared with high-temperature fumaroles on arc volcanoes that display more variable $\delta^{34} \mathrm{~S}(0$ to $+10 \%)$ due to contamination by slab and crustal sources (e.g., Ohba et al. 2008). Further, $\delta^{34} \mathrm{~S}$ values of $\mathrm{S}$ in $\mathrm{H}_{2} \mathrm{~S}$ and $\mathrm{SO}_{2}$ are especially sensitive to redox conditions and $f_{\mathrm{H} 2 \mathrm{O}}$ (Hubberten et al. 1975; Sakai et al. 1982; Marini et al. 1998, 2002; Menyailov et al. 1986), and disproportionation in crater lakes (Oppenheimer 1992; Kusakabe et al. 2000).

\section{VOLCANIC SULFUR EMISSION TO THE ATMOSPHERE}

Most estimates of the volcanic source strength of sulfur to the atmosphere are based on compilations of COSPEC and related observations of lesser emissions from individual volcanoes (many exhibiting long-term degassing), and satellite measurements of the larger, spontaneous releases of $\mathrm{SO}_{2}$ to the upper troposphere and stratosphere associated with large explosive or effusive eruptions (Tables 2-4). These data sources are patchy and go back to the 1970s only, and the statistical distribution of emissions in time and space is thus poorly constrained. At any one time, a few volcanoes appear responsible for substantial fractions of the total volcanic source strength (e.g., Bani et al. 2009). Recently, these have included Nyiragongo (Democratic Republic of Congo), Miyakejima (Japan), Ambrym (Vanuatu), Anatahan (Mariana Islands), Popocatépetl (Mexico) and Mt. Etna (Italy), the latter of which is exceptional not just within Europe but globally as one of the most prodigious sources of volcanic gases to the troposphere. Its average $\mathrm{SO}_{2}$ emission rate is of order $5000 \mathrm{Mg} \mathrm{d}^{-1}$ (Caltabiano 1994) and it is thought to contribute to elevated levels of tropospheric sulfate in southern Italy (Graf et 
al. 1998). It has been suggested that these emissions have caused pollution events in mainland Italy, and even that they have accelerated deterioration of Roman monuments (Camuffo and Enzi 1995).

Table 2. : Examples of large $\mathrm{SO}_{2}$ emitters via non-explosive (passive) degassing during the last $10-15$ year.s

\section{Equivalent}

Volcano $\mathrm{SO}_{2}$ flux $\mathrm{SO}_{2}$ flux Remarks

\section{References}

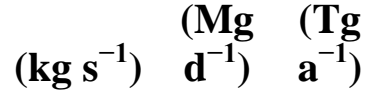

Miyakejima, Japan

Ambrym,

Vanuatu

Popocatépetl, México

Etna, Italy

Nyiragongo,

DRC

Láscar, Chile 28

Bagana, PNG 23

Tungurahua, Ecuador

Kilauea, USA

Ulawun, PNG

38

450

380

380

150

(1)

Average for late 2000-mid 2001; arc basalt

Nakada et al. 2004

Bani et al. 2009 emissions; arc basalt

130004.73 Following explosive eruption in 1996; Delgado$9 \mathrm{Tg}$ emitted between 1995 and 1997 Granados et al. (lava domes \& Vulcanian eruptions); 2001; Roberge basaltic degassing, andesite lavas and et al. 2009 tephra

$64 \quad 5500 \quad 2.02 \quad 1987-1991$ average; alkali basalt

Caltabiano et al. 1994

\section{0}

$280 \quad 1.20$

Lava lake degassing in 2005 (peaks up
to $185 \mathrm{~kg} \mathrm{~s}^{-1}$ ); melilitite/nephelinite lava lake

Sawyer et al.
2008 Carn
2004

Mather et al.

2004a or b?

McGonigle et al. 2004b

Arellano et al.

2008

Sutton et al.

2001

East Rift and Summit
ocean island basalt

7.4 $640 \quad 0.232003$; arc basalt, frequent eruptions
McGonigle et al. 2004b 
Table 3. : Large eruptive emissions of $\mathrm{SO}_{2}$ retrieved from satellite remote sensing observations.

\begin{tabular}{|c|c|c|c|c|}
\hline Volcano & $\begin{array}{l}\text { Eruption } \\
\text { date(s) }\end{array}$ & $\begin{array}{l}\mathrm{SO}_{2} \text { yield } \\
(\mathrm{Tg})\end{array}$ & Remarks & References \\
\hline $\begin{array}{l}\text { Pinatubo, } \\
\text { Phillippines }\end{array}$ & 15 June 1991 & 18 & $\begin{array}{l}20.2 \mathrm{Tg} \text { total for } 12-15 \text { June } \\
1991 \text {; dacite eruption }\end{array}$ & $\begin{array}{l}\text { Guo et al. } \\
2004\end{array}$ \\
\hline $\begin{array}{l}\text { El Chichón, } \\
\text { Mexico }\end{array}$ & $\begin{array}{l}28 \text { March-4 } \\
\text { April, } 1982\end{array}$ & 7 & Trachyandesite eruption & $\begin{array}{l}\text { Bluth et al. } \\
1997\end{array}$ \\
\hline $\begin{array}{l}\text { Nyamuragira, } \\
\text { DRC }\end{array}$ & $\begin{array}{l}26 \text { February } \\
1981-11 \\
\text { January } 1982\end{array}$ & 4.11 & $\begin{array}{l}14 \text { eruptions; } 24.5 \mathrm{Tg} \text { emitted in } \\
\text { total from } 1979-2005 ; \\
\text { phohnolitic tephrite lavas }\end{array}$ & $\begin{array}{l}\text { Bluth and } \\
\text { Carn } 2008\end{array}$ \\
\hline $\begin{array}{l}\text { Nyamuragira, } \\
\text { DRC }\end{array}$ & $\begin{array}{l}8 \text { May-13 June } \\
2004\end{array}$ & 2.6 & Phonolitic tephrite lavas & $\begin{array}{l}\text { Bluth and } \\
\text { Carn } 2008\end{array}$ \\
\hline $\begin{array}{l}\text { Nyamuragira, } \\
\text { DRC }\end{array}$ & $\begin{array}{l}17-31 \text { October } \\
1998\end{array}$ & 2.54 & Phonolitic tephrite lavas & $\begin{array}{l}\text { Bluth and } \\
\text { Carn } 2008\end{array}$ \\
\hline $\begin{array}{l}\text { Nyamuragira, } \\
\text { DRC }\end{array}$ & $\begin{array}{l}25 \text { July-2 } \\
\text { August } 2002\end{array}$ & 2.32 & Phonolitic tephrite lavas & $\begin{array}{l}\text { Bluth and } \\
\text { Carn } 2008\end{array}$ \\
\hline $\begin{array}{l}\text { Nyamuragira, } \\
\text { DRC }\end{array}$ & $\begin{array}{l}24 \text { April-18 } \\
\text { May } 1989\end{array}$ & 2.1 & Phonolitic tephrite lavas & $\begin{array}{l}\text { Bluth and } \\
\text { Carn } 2008\end{array}$ \\
\hline $\begin{array}{l}\text { Galunggung, } \\
\text { Java }\end{array}$ & $\begin{array}{l}5 \text { April -19 } \\
\text { September } 1982\end{array}$ & 1.73 & $\begin{array}{l}\text { Multiple eruptions; beginning } \\
\text { with andesites ending up with } \\
\text { high magnesium basalts }\end{array}$ & $\begin{array}{l}\text { Bluth et al. } \\
1994\end{array}$ \\
\hline $\begin{array}{l}\text { Nyamuragira, } \\
\text { DRC }\end{array}$ & $\begin{array}{l}6 \text { February-7 } \\
\text { March } 2001\end{array}$ & 1.73 & Phonolitic tephrite lavas & $\begin{array}{l}\text { Bluth and } \\
\text { Carn } 2008\end{array}$ \\
\hline $\begin{array}{l}\text { Sierra Negra, } \\
\text { Galápagos }\end{array}$ & 23 October 2005 & 1.7 & $\begin{array}{l}\text { Lava fountains and flows; } \\
\text { tholeiitic basalt }\end{array}$ & $\begin{array}{l}\text { Yang et al. } \\
\text { 2009a or b? }\end{array}$ \\
\hline $\begin{array}{l}\text { Kasatochi, } \\
\text { Alaska }\end{array}$ & $\begin{array}{l}7-8 \text { August } \\
2008\end{array}$ & 1.7 & Explosive andesitic eruption & $\begin{array}{l}\text { Karagulian et } \\
\text { al. } 2010\end{array}$ \\
\hline $\begin{array}{l}\text { Cerro Hudson, } \\
\text { Chile }\end{array}$ & $\begin{array}{l}8-15 \text { August } \\
1991\end{array}$ & 1.5 & Andesitic Plinian eruption & $\begin{array}{l}\text { Krueger et al. } \\
1995\end{array}$ \\
\hline $\begin{array}{l}\text { Nyamuragira, } \\
\text { DRC }\end{array}$ & 5-16 July 1994 & 1.47 & Phonolitic tephrite lavas & $\begin{array}{l}\text { Bluth and } \\
\text { Carn } 2008\end{array}$ \\
\hline $\begin{array}{l}\text { Sierra Negra, } \\
\text { Galápagos }\end{array}$ & $\begin{array}{l}13 \text { November } \\
1979\end{array}$ & 1.2 & Lava flows; tholeiitic basalt & $\begin{array}{l}\text { Bluth et al. } \\
1997\end{array}$ \\
\hline $\begin{array}{l}\text { Alaid, Kuril } \\
\text { islands }\end{array}$ & April 27, 1981 & 1.1 & Explosive basaltic eruption & $\begin{array}{l}\text { Bluth et al. } \\
1997\end{array}$ \\
\hline Wolf Galápagos & August 28, 1982 & 1.1 & $\begin{array}{l}\text { Fire fountains and lava flows; } \\
\text { tholeiitic basalt }\end{array}$ & $\begin{array}{l}\text { Carn et al. } \\
2003\end{array}$ \\
\hline $\begin{array}{l}\text { Mauna Loa, } \\
\text { Hawaii }\end{array}$ & March 25, 1984 & 1 & Lava flows; tholeiitic basalt & $\begin{array}{l}\text { Sharma et al. } \\
2004\end{array}$ \\
\hline $\begin{array}{l}\text { Nyamuragira, } \\
\text { DRC }\end{array}$ & $\begin{array}{l}24 \text { February-4 } \\
\text { March } 1984\end{array}$ & 1 & Phonolitic tephrite lavas & $\begin{array}{l}\text { Bluth and } \\
\text { Carn } 2008\end{array}$ \\
\hline
\end{tabular}


Table 4. : Estimated volcanic emissions of sulfur species to the atmosphere (all figures are for sulfur mass only).

\begin{tabular}{lll} 
Source & \multicolumn{1}{c}{ Sulfur as $\mathbf{S O}_{2}\left(\mathbf{T g ~ a}^{-\mathbf{1}}\right)$ Other S species } \\
Pyle et al. 1996 & $0.45-1.5$ stratospheric & \\
Andres and Kasgnoc 1998 1.9 stratospheric & $3.7\left(\mathrm{OCS}, \mathrm{H}_{2} \mathrm{~S}, \mathrm{H}_{2} \mathrm{SO}_{4}\right)$ \\
& 4.84 tropospheric & \\
& 6.7 total & \\
Halmer et al. 2002 & $1.2-2$ stratospheric & $\mathrm{S}$ as $\mathrm{H}_{2} \mathrm{~S} 0.09-4.7$ stratospheric \\
& $7.5-10.5$ total & $\mathrm{S}$ as $\mathrm{H}_{2} \mathrm{~S} 1.4-35$ total
\end{tabular}

There is a reasonable consensus regarding the magnitude of annual volcanic source strengths of sulfur, though difficulties arise in time-averaging the sporadic but large magnitude releases to the stratosphere from explosive eruptions, and in extrapolating field data for a comparatively small number of observed tropospheric volcanic plumes to the global volcano population (see Wallace and Edmonds 2011, this volume). Historically, the most widely used global dataset is that compiled for the Global Emissions Inventory Activity (GEIA) by Andres and Kasgnoc (1998). This arrives at a global flux of $\mathrm{S}$ from all sources that exceeds $10.4 \mathrm{Tg}$ $\mathrm{yr}^{-1}$. More recently, Halmer et al. (2002) estimated the global volcanic $\mathrm{SO}_{2}$ emission to the atmosphere as 15-21 $\mathrm{Tg} \mathrm{yr}^{-1}$ for the period 1972-2000. Their figures for all S species add considerable uncertainty to the total volcanic sulfur flux (9-46 $\mathrm{Tg} \mathrm{yr}^{-1}$ of S) mainly because of a very large uncertainty in the $\mathrm{H}_{2} \mathrm{~S}$ emission (1.4-35 $\mathrm{Tg} \mathrm{yr}^{-1}$ of $\mathrm{S}$ ). For comparison, the IPCC (2001) estimates of emission rates of other sources of sulfur include anthropogenic (76

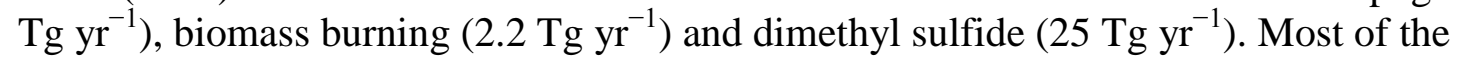
volcanic source strength is from the continuous degassing of many volcanoes worldwide. Using the TOMS dataset and a scaling based on ice core records, Pyle et al. (1996) estimated the medium-term $(\sim 100 \mathrm{yr})$ flux of volcanic sulfur to the stratosphere to be about $1 \mathrm{Tg} \mathrm{yr}^{-1}$ (range of $0.3-3 \mathrm{Tg}^{-1}{ }^{-1}$ ).

An important point that has emerged from additional work is the disproportionate contribution of volcanic sulfur emissions to the global atmospheric sulfate budget compared with other sources of sulfur including anthropogenic and oceanic emissions. Episodic, large magnitude eruptions are the principal perturbation to stratospheric aerosol levels (e.g., the $30 \mathrm{Tg}$ of sulfate generated by the $1991 \mathrm{Mt}$ Pinatubo eruption). In the troposphere, the picture is less clear, but modeling suggests that up to $40 \%$ of the global tropospheric sulfate burden may be volcanogenic (Graf et al. 1997), though Stevenson et al. (2003) and Chin and Jacob (1996) obtain lower figures (14 and 18\%, respectively), in part due to use of a lower volcanic sulfur source strength. In any case, these figures all exceed the fraction of the sulfur source to the atmosphere that is volcanogenic (around 10\%) because of the generally higher altitudes of entrainment of volcanic sulfur compared with biogenic (DMS) or anthropogenic sources, and hence the longer residence time of volcanic $\mathrm{SO}_{2}$ compared with other sources. This results in lower deposition rates, more conversion of $\mathrm{SO}_{2}$ to sulfate, and a longer residence time of the higher altitude aerosol. Sulfate aerosol plays a significant role in the Earth's radiation budget because it may both backscatter incoming short-wave solar radiation and absorb outgoing long-wave radiation; the competition between these processes depending strongly on particle size. In addition, sulfate aerosol can have a secondary radiative effect by promoting cloud 
condensation or modification of the microphysical properties and longevity of existing clouds (Graf et al. 1997; Gassó 2008). Changes in time and space in this "background" emission could represent an important forcing factor that has yet to be characterized.

A more recent database on volcanic $\mathrm{SO}_{2}$ emissions compiled by Diehl (2009) is based on the Global Volcanism Program data set on volcanic eruptions (http://www.volcano.si.edu/) and prior work of Berresheim and Jaescke (1983), Andres and Kasgnoc (1998), Halmer et al. (2002), and Blake (2003) covers the period 1979-2009.

\section{Ice cores}

One of the most valuable archives of past atmospheric and climatic conditions on Earth is found in the polar regions and some lower latitude ice caps and glaciers in the Central Andes (e.g., Kellerhals et al. 2010), the Himalayas and Tibet. Ice cores contain a deposition signal (representing the fallout of atmospheric gases and particles to the surface) and a postdepositional signal (compaction, chemical diffusion, wind deflation and re-deposition). Oxygen isotopes and the calcium ion record are essential indicators of climatic variability, while peaks in sulfate ions $\left(\mathrm{SO}_{4}{ }^{2-}\right)$ and in electrical conductivity of the ice indicate volcanic aerosol fallout. The pioneering work on the volcanic acid layers preserved in ice cores was carried out by Claus Hammer and colleagues (e.g., Hammer 1977; Hammer et al. 1980). Glaciochemical stratigraphy thereby reveals a vast amount of information on past volcanism (Fig. 10). One of the striking revelations of the ice core record is the evidence for numerous great eruptions, which have not otherwise been recognized in tephra records. One caveat to the approach is that although the dating of the ice core by counting of seasonal layers is fairly robust, it is not fail-safe. The greater the depth from which the core is retrieved, the more likely it is to have suffered deformation (e.g., Baillie 2010). 


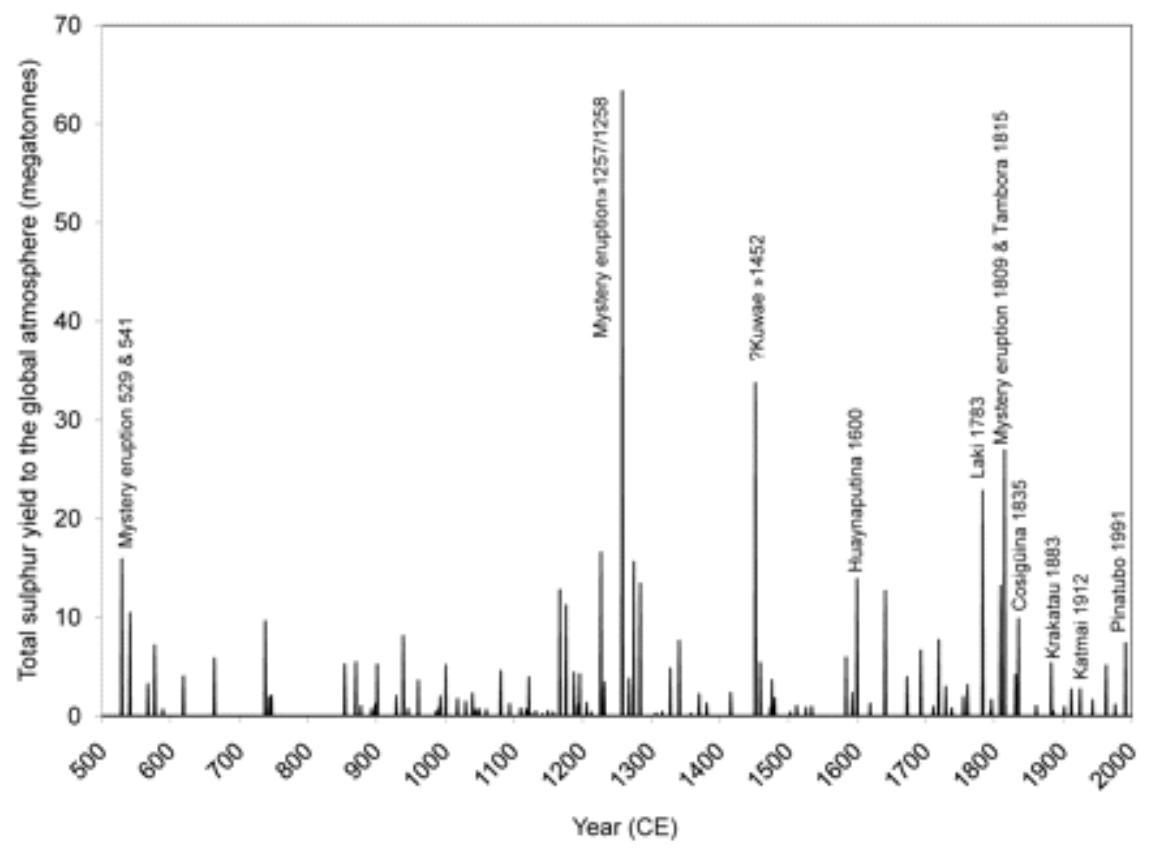

Figure 10. : Plot of GISP2 volcanic sulfate markers for the past two millennia based on statistical analysis (Zielinski et al. 1994). Several large anomalies have not been traced to the responsible volcanoes, including the prominent AD 640 and 1259 peaks. Data provided by the National Snow and Ice Data Center, University of Colorado at Boulder, and the WDC-A for Paleoclimatology, NGDC, Boulder, CO, USA.

One of the ice cores most closely studied to date for its volcanic record is the Greenland Ice Sheet Project 2 (GISP2) core. Initial efforts took the record back to 7000 BCE with the core measured at biennial resolution (Zielinski et al. 1994). All ice core records of volcanism are affected to greater or lesser extent by the proximity of the core sites to active volcanoes. While some large explosive eruptions in the tropics have sourced fallout identified in cores from both polar regions (Gao et al. 2007, 2008), records are generally biased. For instance, the Greenland records provide better records of eruptions in Iceland, Alaska, the Aleutians and Kamchatka. Particles from high-northern latitude eruptions tend to reach the Arctic ice sheets within months of eruption, while acid fallout from tropical eruptions peaks up to 1-2 years later depending on prevailing circulation of the upper atmosphere. Fallout from eruptions south of the tropics is unlikely to make it to the Arctic (and similarly, fallout from boreal eruptions is unlikely to reach the Antarctic). The GISP2 team later extended the ice core record of volcanism back to $110 \mathrm{ka}$ ago (Zielinski et al. 1996). More recently established, the European Project for Ice Coring in Antarctica (EPICA) record goes back to around $800 \mathrm{ka}$ ago (EPICA 2004) though the portion suitable for reliable identification of volcanic sulfate may cover only the last $400 \mathrm{ka}$ (Traversi et al. 2009).

An important application of the ice core record is in providing estimates of the sulfur output of large eruptions (Table 5). The most widely used calibration for sulfate concentration in an ice core is based on measurements of radioactivity due to fallout from atmospheric nuclear weapons tests carried out in the 1950s and 1960s. Because the yield of these various bombs is known, a correlation can be established between the quantities of radionuclides released into the atmosphere and the concentration of radioactive fallout measured in the ice. This same 
correlation can then be applied to the volcanic markers, assuming that the volcanic sulfate was transported by comparable atmospheric circulation patterns, from similar latitude, and so on, which is difficult to gauge for ancient eruptions (as mentioned above, the responsible volcano is often unidentified). Very low snow deposition rates and post-depositional processes that affect the ice, such as densification, diffusion, and wind deflation or re-deposition, and the contributions from sources of sulfur (including the oceans), also complicate interpretation of ice core sulfate records. Nevertheless, multiple estimates of stratospheric aerosol loading of eruptions are reasonably convergent, and are consistent with estimates obtained by other methods (e.g., based on the petrological methods discussed earlier), providing some confidence in the approach (Fig. 2).

Table 5. : Estimated sulfur yield from selected major historic and prehistoric eruptions (magnitude $>10^{13} \mathrm{~kg}$ ).

\section{Eruption year and volcano}

$$
\underset{(\mathrm{kg})^{\mathrm{a}}}{\operatorname{Magnitude}} \quad \begin{gathered}
\text { Sulfur yield } \\
(\mathrm{Tg} \text { of } S)^{\mathrm{b}}
\end{gathered}
$$

\section{Reference}

${ }^{\text {a }}$ Total eruption magnitude for multiple phases of eruption and combining tephra deposits from both Plinian and co-ignimbrite clouds and associated pyroclastic density current deposits where applicable; ${ }^{b}$ Stratospheric sulfur yield based on ice core sulfate deposition; ${ }^{\text {c but see }}$ Németh et al. (2007) for an alternative viewpoint on the Kuwae caldera; ${ }^{d}$ since this estimate is based on ice core sulfate deposition, it may reflect the cumulative aerosol fallout of other notable 1902 eruptions, i.e., Mont Pelée (Martinique) and Soufrière (St. Vincent) as well as

\begin{tabular}{|c|c|c|c|}
\hline 73 ka BP Toba, Indonesia & $7 \times 10^{15}$ & $35-3300$ & $\begin{array}{l}\text { Summarized in Oppenheimer } \\
\text { 2002; Chesner and Luhr } 2010\end{array}$ \\
\hline 230 CE Taupo, New Zealand & $7.7 \times 10^{13}$ & $? 6.5$ & ${ }^{\mathrm{b}}$ Zielinksi et al. 1996 \\
\hline $\begin{array}{c}\text { 2935 CE Baitoushan (aka } \\
\text { Chanbaishan, Pektusan), } \\
\text { China/North Korea }\end{array}$ & $5.8 \times 10^{13}$ & $>2$ & $\begin{array}{l}\text { Horn and Schmincke 2000; } \\
\text { Nakamura et al. } 2007\end{array}$ \\
\hline 1257/8 CE, Unknown & $?$ & $>100$ & Oppenheimer 2003 \\
\hline $1452{ }^{c}$ Kuwae, Vanuatu & $7.5-15 \times 10^{13}$ & $>6.5-13$ & $\begin{array}{l}\text { Scaillet et al. 2003; Witter } \\
\text { and Self } 2007\end{array}$ \\
\hline 1600 Huaynaputina, Peru & $2.1 \times 10^{13}$ & $26-55$ & Costa et al. 2003 \\
\hline 1815 Tambora, Indonesia & $7.4 \times 10^{13}$ & 28 & Self et al. 2004 \\
\hline 1883 Krakatau, Indonesia & $3.0 \times 10^{13}$ & 15 & ${ }^{\mathrm{b}}$ Zielinksi et al. 1996 \\
\hline 1902 Santa Maria, Guatemala & $2.2 \times 10^{13}$ & $11^{\mathrm{d}}$ & ${ }^{\mathrm{b}}$ Zielinksi et al. 1996 \\
\hline 1912 Katmai, Alaska & $2.5 \times 10^{13}$ & 10 & ${ }^{\mathrm{b}}$ Zielinksi et al. 1996 \\
\hline 1991 Pinatubo, Philippines & $1.3-1.8 \times 10^{13}$ & 9 & Guo et al. 200 \\
\hline
\end{tabular}
the Santa Maria event.

\section{ATMOSPHERIC AND CLIMATIC IMPACTS OF SULFUR DEGASSING}

There is considerable interest in volcanic emissions of sulfur compounds because of their role in atmospheric radiation and climate, the hydrological cycle, acid precipitation, and air quality. The main protagonist in volcanic forcing of climate is the sulfate aerosol formed by oxidation of sulfur gases released to the upper atmosphere. This section focuses on the impacts of major, sulfur-rich explosive eruptions on the stratosphere and climate, and of passive degassing on tropospheric chemistry and ecosystems. 


\section{Chemical schemes relevant to volcanic sulfur emissions}

Volcanic plumes obviously affect the composition of the atmosphere they pass through. Similarly, the low-temperature, oxidizing environment of the atmosphere results in profound changes in the brew of volcanic gases that leave the vent. As a result, the atmospheric chemistry of volcanic plumes is complex. The mixture of ash particles, liquid droplets, soluble salts, ice crystals, and volcanic gases can absorb and scatter solar radiation, resulting in temperature changes. Since the rates of many chemical reactions in the atmosphere are temperature-dependent, and as temperature controls the phase — solid, liquid, gas — of atmospheric constituents, these effects influence atmospheric composition. Changes in shortwave radiation also affect photochemical processes contingent on levels of ultraviolet and visible light. In the stratosphere, the most significant chemical role of volcanic aerosols is in providing surfaces on which atmospheric gases can react (heterogeneous reactions). Multiphase reactions involving diffusion into a liquid droplet and reaction within the liquid are also important.

\section{High-temperature chemistry at the vent.}

The presence of highly oxidized species in volcanic emissions-near-source $\mathrm{SO}_{4}{ }^{2-}$ particles (Allen et al. 2002; Mather et al. 2003a,b), $\mathrm{ClO}$ and OClO (Bobrowski et al. 2007), BrO (Bobrowski et al. 2003; Oppenheimer et al. 2006), $\mathrm{NO}_{\mathrm{y}}$ (Mather et al. 2004a; Oppenheimer et al. 2005, 2010) - is not predicted by equilibrium models for high-temperature magmatic gases (e.g., Symonds and Reed 1993). Even relatively oxidized magmatic gases do not thermodynamically support the formation of these species. Instead, magmatic gases may be partially oxidized at the vent by atmospheric gases. A simple thermal model of binary mixing (Fig. 11; heat capacities are assumed equal) between magmatic gas (e.g., volume $=V_{\mathrm{M}}, T=$ $1273 \mathrm{~K}, f_{\mathrm{O} 2}=10^{-8}$ bar) and atmospheric gas (e.g., volume $=V_{\mathrm{A}}, T=273 \mathrm{~K}, f_{\mathrm{O} 2}=0.21 \mathrm{bar}$ ) shows that tremendous increases in $f_{\mathrm{O} 2}$ may occur with minimal change in the temperature. Such a thermal model predicts that highly oxidized, high-temperature mixtures will form at vents. However, a limitation is that chemistry is not considered and reduced species in the magmatic gas (e.g., $\mathrm{H}_{2} \mathrm{~S}, \mathrm{H}_{2}, \mathrm{CO}$ ) would buffer the oxidation state of mixture to some extent. A kinetic model would be desirable to understand better the chemistry occurring at the vent, but relevant mechanisms and reaction rates remain unknown despite the development of kinetic models in other high-temperature systems (e.g., combustion and chemical synthesis). 

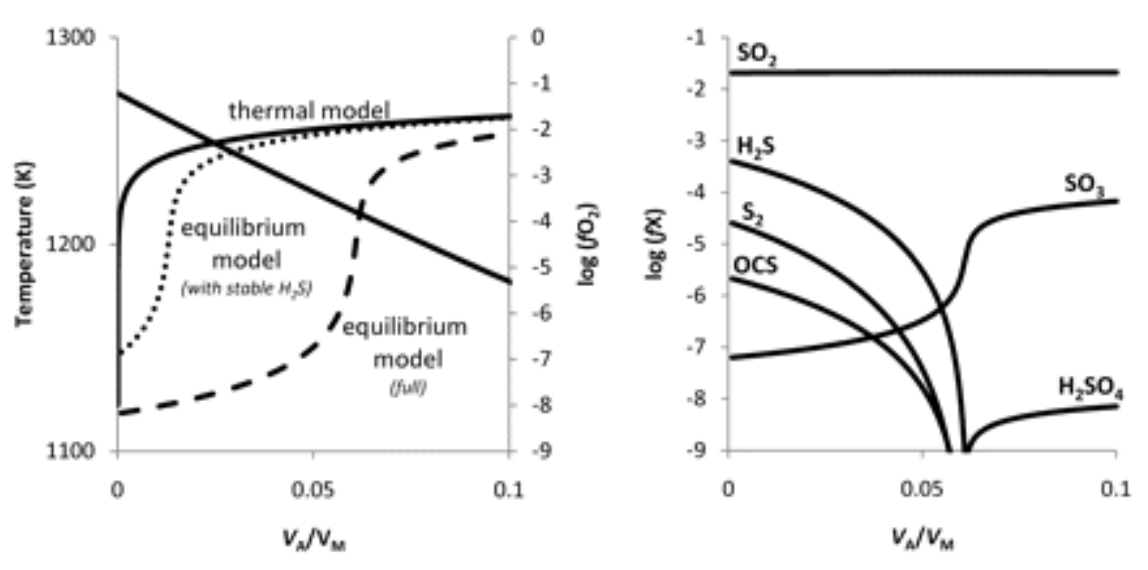

Figure 11. : Plots of (a) thermal and equilibrium model calculations for temperature and $f_{\mathrm{O} 2}$ in mixtures forming at the volcanic vent as function of the volume fraction of mixing, $V_{\mathrm{A}} / V_{\mathrm{M}}$. (b) $\mathrm{S}$ speciation assuming full thermodynamic equilibrium.

A simplified approach to investigate vent chemistry relies on the fact that reaction rates increase with increasing temperature, promoting the rapid attainment of equilibrium. With the assumption that full equilibrium is attained and maintained within the high-temperature mixture of magmatic and atmospheric gases, modeling with an averaged magmatic gas composition (Gerlach 2004b; Martin et al. 2006) predicts significant changes in $f_{\mathrm{O} 2}$ and sulfur speciation as mixing occurs (Fig. 11). The main features are losses of reduced S species $\left(\mathrm{H}_{2} \mathrm{~S}\right.$, $\left.\mathrm{S}_{2}, \mathrm{OCS}\right)$ and gains in oxidized $\mathrm{S}$ species $\left(\mathrm{SO}_{3}, \mathrm{H}_{2} \mathrm{SO}_{4}\right)$ around a compositional discontinuity (i.e., a step increase in $f_{\mathrm{O} 2}$; Gerlach and Nordlie 1975). Equivalent trends have been shown for other elements, e.g., $\mathrm{C}, \mathrm{N}, \mathrm{Br}, \mathrm{Cl}$. The location of the compositional discontinuity can be calculated for a magmatic gas composition simply by the amount of $\mathrm{O}_{2}$ required to oxidize all $\mathrm{H}_{2} \mathrm{~S}$ and $\mathrm{H}_{2}$ (Martin et al. 2006), implying that more oxidized magmatic gases with lower $\mathrm{H}_{2} \mathrm{~S}$ and $\mathrm{H}_{2}$ are more likely to the support the formation of oxidized species. There are, however, indications from field measurements that full equilibrium may not be attained at the vent since the model predicts mutual exclusivity of $\mathrm{H}_{2} \mathrm{~S}$ and oxidized species, which is inconsistent, for instance, with the presence of both $\mathrm{H}_{2} \mathrm{~S}$ (Aiuppa et al. 2005b) and $\mathrm{BrO}$ (Oppenheimer et al. 2006) in Mt. Etna's plume. Further, the measurements of the atmospheric plume emitted from Mt. Etna reveal a $\mathrm{SO}_{2} / \mathrm{H}_{2} \mathrm{~S}$ ratio consistent with the predicted magmatic gas phase (Aiuppa et al. 2005b) and so $\mathrm{H}_{2} \mathrm{~S}$ may not always react rapidly at high temperature (see also discussion on tropospheric chemistry below). Kinetic stability of $\mathrm{H}_{2} \mathrm{~S}$ at high temperature would lower the compositional discontinuity, increase $f_{\mathrm{O} 2}$ and increase the abundance of oxidized species in the mixture since atmospheric $\mathrm{O}_{2}$ is no longer consumed by reaction with $\mathrm{H}_{2} \mathrm{~S}$ (Fig. 11; Martin et al. 2009). This problem highlights the key importance of $\mathrm{H}_{2} \mathrm{~S}_{/} \mathrm{SO}_{2}$ measurements, and measurements of other redox pairs (e.g., $\mathrm{H}_{2} / \mathrm{H}_{2} \mathrm{O}, \mathrm{CO} / \mathrm{CO}_{2}$ ), in investigating the chemistry occurring at volcanic vents.

Equilibrium models show that the highly oxidized, high-temperature conditions of the vent play an important role in converting relatively unreactive species (e.g., $\mathrm{H}_{2} \mathrm{~S}, \mathrm{HCl}, \mathrm{HBr}, \mathrm{N}_{2}$ ) into more reactive species, such as $\mathrm{SO}_{3}, \mathrm{Cl}, \mathrm{Br}$ and $\mathrm{NO}$ (Fig. 11; Mather 2008). However, the most abundant "reactive" species at the vent are generally different from those measured in the plume (e.g., $\mathrm{SO}_{4}{ }^{2-}, \mathrm{ClO}, \mathrm{OClO}, \mathrm{BrO}, \mathrm{NO}_{2}, \mathrm{HNO}_{3}$ ), so further chemical processing must occur beyond the vent. Sulfate ions may form simply by reaction of hygroscopic $\mathrm{SO}_{3}$ with 
water, as indicated by isotopic studies of near-source $\mathrm{SO}_{4}{ }^{2-}$ at Masaya volcano (Mather et al. 2006) that show $\delta^{18} \mathrm{O}$ is close the magmatic values. Additionally, $\mathrm{SO}_{4}{ }^{2-} / \mathrm{SO}_{2}$ ratios in nearsource volcanic emissions are typically on the order of $10^{-2}$ (Allen et al. 2002; Mather et al. 2004b; Martin et al. 2008, 2010b) and so in good agreement with the results from equilibrium modeling. Nevertheless, much remains to be done to reconcile observations and models and advance our understanding of the first seconds of the chemical and physical evolution of magmatic volatiles on exposure to the atmosphere.

\section{Tropospheric chemistry.}

The major fates of tropospheric $\mathrm{SO}_{2}$ are dry and wet deposition, and oxidation to sulfate. In the gas phase, hydroxyl rapidly reacts with $\mathrm{SO}_{2}$ by addition:

$\mathrm{OH}+\mathrm{SO}_{2}+\mathrm{M} \rightarrow \mathrm{HOSO}_{2}+\mathrm{M}$

where $M$ represents a molecule (usually $\mathrm{N}_{2}$ ) that absorbs excess kinetic energy from the reactants (Hewitt 2001). The reaction rate is second order in the troposphere. In unpolluted air, $\mathrm{OH}$ is produced by the photolysis of ozone and the subsequent reaction of oxygen atoms with water vapor. In polluted air, the photolysis of nitrous acid (HONO) and hydrogen peroxide $\left(\mathrm{H}_{2} \mathrm{O}_{2}\right)$ yields $\mathrm{OH}$ directly (Hewitt 2001). Once formed, the free radical $\mathrm{HOSO}_{2}$ reacts rapidly with oxygen to form $\mathrm{SO}_{3}$, which in turn reacts rapidly with water vapor to form sulfuric acid, $\mathrm{H}_{2} \mathrm{SO}_{4}$ :

$\mathrm{HOSO}_{2}+\mathrm{O}_{2} \rightarrow \mathrm{HO}_{2}+\mathrm{SO}_{3}$

$\mathrm{SO}_{3}+\mathrm{H}_{2} \mathrm{O} \rightarrow \mathrm{H}_{2} \mathrm{SO}_{4}$

Möller (1980) calculated mean tropospheric e-folding times of $12 \mathrm{~d}$ for homogenous gas-phase oxidation by $\mathrm{OH}$ radicals (i.e., the time taken for $\mathrm{SO}_{2}$ abundance to decay exponentially to $1 / 2.718$ of its initial level). However, much faster oxidation can occur through heterogeneous reactions. Sulfur dioxide can dissolve in aqueous aerosol, establishing an equilibrium with its ionic products $\left(\mathrm{SO}_{2} \cdot \mathrm{H}_{2} \mathrm{O}\right.$, bisulfite ions $\left(\mathrm{HSO}_{3}{ }^{-}\right)$and sulfite ions $\left(\mathrm{SO}_{3}{ }^{2-}\right)$ :

$$
\begin{aligned}
& \mathrm{SO}_{2}+\mathrm{H}_{2} \mathrm{O}=\mathrm{SO}_{2} \cdot \mathrm{H}_{2} \mathrm{O} \\
& \mathrm{SO}_{2} \cdot \mathrm{H}_{2} \mathrm{O}=\mathrm{HSO}_{3}^{-}+\mathrm{H}^{+} \\
& \mathrm{HSO}_{3}^{-}=\mathrm{SO}_{3}^{2-}+\mathrm{H}^{+}
\end{aligned}
$$

The $\mathrm{pH}$ of the aerosol controls the equilibrium and hence speciation. The oxidation of S(IV) to S(VI) typically involves ozone or hydrogen peroxide (e.g., Martin and Damschen 1981):

$$
\begin{aligned}
& \mathrm{S}(I V)+\mathrm{O}_{3} \rightarrow S(V I)+\mathrm{O}_{2} \\
& S(I V)+\mathrm{H}_{2} \mathrm{O}_{2} \rightarrow S(V I)+\mathrm{H}_{2} \mathrm{O}
\end{aligned}
$$

The reaction of $\mathrm{S}(\mathrm{IV})$ with ozone is rapid in the aqueous phase but is more $\mathrm{pH}$ dependent (and less effective for $\mathrm{pH}<4$ ) than the reaction with $\mathrm{H}_{2} \mathrm{O}_{2}$ (Eatough et al. 1994; Hewitt 2001). $\mathrm{S}(\mathrm{IV})$ can also be oxidized by metal catalysts such as $\mathrm{Mn}^{2+}$ and $\mathrm{Fe}^{2+}$, which could have significant abundance in some volcanic aerosol. 
Möller (1980) calculated mean tropospheric e-folding times of just $0.1-10 \mathrm{~d}$ for oxidation on the surfaces of particles, and $<6 \mathrm{~h}$ for oxidation within aqueous particles by $\mathrm{H}_{2} \mathrm{O}_{2}$ and $\mathrm{O}_{3}$. The short e-folding time of tropospheric $\mathrm{SO}_{2}$ does not itself pose a problem for traverse or scanning measurements of $\mathrm{SO}_{2}$ fluxes since these are generally measured close to source (plume age $<1 \mathrm{~h}$ ). However, as discussed above, recent studies have highlighted the oxidizing nature of volcanic plumes compared to the background troposphere (von Glasow et al. 2009). In the specific case of $\mathrm{SO}_{2}$, the observation is that measured fluxes may decrease significantly over relatively small distances, suggesting e-folding times much shorter than $6 \mathrm{~h}$. The shortest reported measured e-folding time is $17 \mathrm{~min}$ at Soufrière Hills volcano on Montserrat (Oppenheimer et al. 1998b) and a more recent measurement reported an e-folding time of $3 \mathrm{~h}$ (Rodriguez et al. 2008). Measurements elsewhere include Mt. St. Helens (>100 d; Martin et al. 1986), Masaya (28 h; McGonigle et al. 2004a) and Mt. Erebus ( 1 d; Oppenheimer et al. 2010).

Rodriguez et al. (2008) suggest that the apparently shorter e-folding times at Soufrière Hills volcano relate to the humid conditions promoting $\mathrm{SO}_{2}$ oxidation in aqueous particles; if true, this may suggest a systematic underestimation of $\mathrm{SO}_{2}$ fluxes from other volcanoes in comparable climates. The presence of volcanic sulfate (both near-source and formed by low temperature $\mathrm{SO}_{2}$ oxidation) has a number of implications for tropospheric chemistry. Volcanic sulfate aerosols act as cloud condensation nuclei (e.g., Mather et al. 2003a), which enable condensation of water vapor to form clouds. Similarly, the volcanic sulfate aerosols may lead to physical changes in existing clouds by the introduction of additional cloud condensation nuclei. The first satellite observations of this phenomenon showed decreased particle size and increased particle number in impacted clouds due to increased competition of water vapor (Gassó 2008). Additionally, the presence of sulfate would cause acidification of existing aerosol (e.g., von Glasow et al. 2009), potentially leading to increased rates of acidcatalyzed aqueous reactions and the revolatilization of acidic gases (e.g., $\mathrm{HCl}, \mathrm{HBr}, \mathrm{HF}$, $\mathrm{HNO}_{3}$ ).

The major fate of tropospheric $\mathrm{H}_{2} \mathrm{~S}$ is $\mathrm{H}$-abstraction by $\mathrm{OH}$ radicals (with a mean e-folding time of $12 \mathrm{~h}$; Jaeschke et al. 1980). While $\mathrm{OH}$ radicals are formed through high-temperature chemistry at the vent (e.g., Gerlach 2004b), kinetic model studies at low temperature (Aiuppa et al. 2007b) have shown that the $\mathrm{OH}$ concentrations would be too low to result in significant losses of $\mathrm{H}_{2} \mathrm{~S}$ over short timescales (i.e., $\sim 1 \mathrm{~h}$ ). The analogous reactions between $\mathrm{H}_{2} \mathrm{~S}$ and halogen radicals $(\mathrm{Cl}, \mathrm{Br})$ are predicted to be much faster when high-temperature vent chemistry is considered, with $\mathrm{H}_{2} \mathrm{~S}$ being removed by $\mathrm{Cl}$ after a few seconds (Aiuppa et al. $2007 \mathrm{~b})$. These results are inconsistent with measurements showing a stable $\mathrm{H}_{2} \mathrm{~S}_{\mathrm{SO}} \mathrm{SO}_{2}$ ratio in Mt. Etna's plume, consistent with magmatic degassing and no overprinting by subsequent kinetic processing. Possible explanations for this mismatch are given as either that $\mathrm{Cl}$ production is exaggerated by the model for high-temperature vent chemistry or a missing loss process for $\mathrm{Cl}$. The latter possibility was not thought likely since high $\mathrm{Cl}$ concentrations were required to explain observation of high $\mathrm{ClO}$ by differential optical absorption spectroscopy (Bobrowski et al. 2007). However, it now appears that these early $\mathrm{ClO}$ measurements are unreliable (Kern et al. 2009) so a missing loss process for $\mathrm{Cl}$ remains an important possibility.

As previously indicated, the tropospheric chemistry of volcanic $\mathrm{S}$ does not occur in isolation from other volcanic emissions. Much of the oxidizing nature of volcanic plumes may stem from the high concentrations of sulfate aerosol, not as a reactant in the strict sense, but as a medium for other reactions to take place within and on the aerosol. The importance of the aerosol has been emphasized in kinetic models (e.g., Roberts et al. 2009; von Glasow 2010) 
for $\mathrm{Br}, \mathrm{Cl}$ and $\mathrm{NO}$ oxidation. Additionally, recent work by von Glasow (2010) highlights the potential role of $\mathrm{SO}_{2}$ in $\mathrm{Hg}$ speciation in volcanic emissions. This is an issue of key importance because while $\operatorname{Hg}(0)$ is an unreactive insoluble gas that is transported globally, $\mathrm{Hg}$ (II) occurs as reactive gases and particles that deposit rapidly and proximally. This may result in elevated and potentially harmful levels of $\mathrm{Hg}$ deposition around active volcanoes. The key reactions are as follows (where $\mathrm{X}=\mathrm{Br}, \mathrm{Cl}$ ):

$H g+2 \mathrm{X} \rightarrow \mathrm{HgX}_{2}$

$\mathrm{HgX}_{2}+\mathrm{SO}_{2} \rightarrow \mathrm{Hg}+\mathrm{X}_{2}+\mathrm{SO}_{2}$

High-temperature models of vent chemistry (Bagnato et al. 2007) predict that $\mathrm{Hg}$ (II) comprises $1 \%$ of total $\mathrm{Hg}$, while kinetic modeling (von Glasow 2010) shows that the amount of $\mathrm{Hg}$ (II) would increase due to oxidation by halogen radicals $(\mathrm{Br}, \mathrm{Cl})$. However, at high concentrations of $\mathrm{SO}_{2}$, any $\mathrm{HgX}_{2}$ (i.e., $\mathrm{Hg}$ (II)) formed would be rapidly converted back to $\mathrm{Hg}$. While the prospect of local $\mathrm{Hg}$ deposition depends on a series of uncertain rate constants, it is clearly that case that $\mathrm{S}$ chemistry could play a critical role in determining $\mathrm{Hg}$ speciation after emission.

\section{Impacts of tropospheric sulfur emissions from volcanoes}

From local to regional scales, volcanic emissions can result in significant environmental and environmental health consequences, including destruction of agricultural crops, contamination of pasture, and human respiratory morbidity and cardiovascular mortality. Large lava eruptions, such as that of Laki (Iceland) in 1783-1784, which released an estimated $120 \mathrm{Tg}$ of $\mathrm{SO}_{2}$, have resulted in major pollution episodes responsible for regional-scale extreme weather, agricultural losses, and elevated human morbidity and mortality (Thordarson et al. 1996; Witham and Oppenheimer 2005; Oppenheimer 2011).

Thanks largely to the work following the 1991 eruption of Mt. Pinatubo, there is now a good understanding of the stratospheric impacts of volcanic eruption clouds, at least for emissions on this scale. In contrast, the impacts of tropospheric volcanic plumes are rather poorly known (Table 2). This partly stems from a wide spectrum of emissions and emission styles (e.g., continuous degassing, minor eruptions), rapid transport of some components to the Earth's surface, and the greater concentration and variability of $\mathrm{H}_{2} \mathrm{O}$ in the troposphere. Reactive $\mathrm{S}$, $\mathrm{Cl}$ and $\mathrm{F}$ compounds may be present in both the gas and particle phase in volcanic plumes, and are typically co-emitted with many other volatile species, including water vapor, and with silicate ash particles. Once in the troposphere, physical and chemical processes convert gaseous $\mathrm{SO}_{2}$ to sulfate, while gaseous $\mathrm{HF}$ and $\mathrm{HCl}$ establish equilibria with aqueous phase $\mathrm{H}^{+}$, $\mathrm{F}^{-}$and $\mathrm{Cl}^{-}$.

Increasing interest in the impacts of tropospheric volcanic emissions on terrestrial and aquatic ecology and on human and animal health is driving more research into the tropospheric chemistry and transport of volcanic plumes. This will be of particular importance in understanding the long-range pollution impacts of volcanic clouds (that might be expected from future eruptions of the scale as that of Laki in 1783-1784). 


\section{Impacts on agriculture, ecosystems and air quality.}

Volcanic volatiles emitted into the atmosphere are ultimately wet or dry deposited at the Earth's surface. The chemical and physical form in which they are deposited, and the spatial and temporal distribution of deposition, are strongly controlled by atmospheric chemistry and transport of the volcanic plume. Various components of volcanic emissions (including acid species and heavy metals; e.g., Martin et al. 2010a) can be taken up by plants, and can have both harmful and beneficial effects. The detrimental effects are generally either mediated through acidification of soils (by dry or wet deposition) or by direct fumigation of foliage (e.g., respiration of acid gases through stomata).

Individual passively degassing volcanoes can also represent major pollution sources. For example, Mt. Etna continuously emits of order $70 \mathrm{~kg} \mathrm{~s}^{-1} \mathrm{SO}_{2}$, and substantially elevates tropospheric sulfate in southern Italy (Graf et al. 1998). Very fine (sub-micron) and highly acidic ( $\mathrm{pH}$ about 1) aerosol is also emitted from open-vent volcanoes such as Mt. Etna and Masaya (Allen et al. 2002, 2006; Mather et al. 2003b). Adverse environmental and health impacts are observed downwind of many degassing volcanoes, including Masaya (Nicaragua), Kilauea (Hawai'i), Poás (Costa Rica), Miyakejima (Japan) and Popocatépetl (Mexico) (e.g., Baxter et al. 1982; Mannino et al. 1996; Delmelle et al. 2003; Fujita et al. 2003). Downwind of Masaya volcano, $\mathrm{SO}_{2}$ levels exceed background levels at the surface across an area of $1250 \mathrm{~km}^{2}$, and an estimated 50,000 people are exposed to concentrations of $\mathrm{SO}_{2}$ exceeding WHO air quality standards ( 125 ppbv over $24 \mathrm{~h} ; 50$ ppb over 1 year; Baxter et al. 1982; Baxter 2000; Delmelle et al. 2001, 2002). Symptoms of respiratory illness are commonly reported anecdotally, though formal epidemiological studies have yet to be undertaken.

Measurements in Mexico City have indicated the direct influence of Popocatépetl volcano's emissions on urban air quality (e.g., Raga et al. 1999; de Foy et al. 2009). This hints at the potential impacts of future eruptions on the scale of the Laki 1783-1784 episode, with longrange transport of $\mathrm{SO}_{2}$ and sulfate aerosol reaching European cities, where air quality standards are already surpassed at certain times of the year. Air quality in Hawai' $i$ is affected by "vog" (volcanic fog) associated with $\mathrm{SO}_{2}$ and sulfate aerosol from Kilauea's plume (Sutton and Elias 1993; Longo and Yang 2008; Longo et al. 2008, 2010; Longo 2009). However, a study of healthy residents on the Big Island of Hawai'i found no appreciable effects of the "vog" on the autonomic nervous system (Chow et al. 2010). A study on Réunion revealed elevated exposure to $\mathrm{SO}_{2}$ in coastal regions during eruptive episodes but limited clinical evidence for respiratory consequences of the volcanic emissions (Viane et al. 2009; Bhugwant et al. 2009).

Chemical burning of leaves and flowers of vegetation downwind of the crater is a common observation during degassing crises of Masaya volcano, with substantial economic impact from the loss of coffee crops (Delmelle et al. 2001, 2003). A further common response to increased gas concentrations is defoliation, as was recently observed close to the April 2007 eruption on Réunion (Martin et al. 2010a). More minor responses to exposure to $\mathrm{SO}_{2}$ including changes in leaf permeability (Percy and Baker 1988) and stomatal conductance (Smith 1990), which affect the uptake of aerosol and gas into the leaf. $\mathrm{SO}_{2}$ can cause direct damage to plants once it is taken up by the foliage (Smith 1990). The response, however, can be very variable, depending on dosage, atmospheric conditions, leaf type and pre-existing plant health (e.g., Linzon et al. 1979; Winner and Mooney 1980; Smith 1990). In general, chronic exposures to $\mathrm{SO}_{2}$ concentrations of a few 10s or 100s ppb are sufficient to affect plant 
ecosystems, decrease agricultural productivity and cause visible foliar chlorosis and necrosis (Winner and Mooney 1980).

The impacts of sulfate deposition on soils have been investigated widely in the context of anthropogenic pollution, indicating that the $\mathrm{SO}_{4}{ }^{2-}$ retention capacity of soils varies widely and can be expected to dictate the ecosystem disturbance of volcanogenic sulfur deposition. Anion sorption in soils is directly related to the soil mineralogy and hence, to the soil parent material. Delmelle et al. (2001) estimated that the amount of $\mathrm{SO}_{2}$ and $\mathrm{HCl}$ dry-deposited within $44 \mathrm{~km}$ of Masaya volcano generates an equivalent $\mathrm{H}^{+}$flux ranging from $<1$ to $30 \mathrm{mg}$ $\mathrm{m}^{-2}$ day $^{-1}$. Sustained acid loading at these rates can severely impact soil chemistry, reflected downwind of Masaya in low $\mathrm{pH}$ and depressed base-saturation contents of soils (Parnell 1986) as metals are displaced from the soil complex by $\mathrm{H}^{+}$.

\section{The atmospheric and climatic impact of the 1991 eruption of Mt. Pinatubo}

The principal source of sulfur to the stratosphere is the episodic injection of $\mathrm{SO}_{2}$ (and/or $\mathrm{H}_{2} \mathrm{~S}$ ) from major eruptions. Once in the stratosphere, $\mathrm{SO}_{2}$ is oxidized to sulfuric acid at rates determined by the availability of $\mathrm{OH}$ radicals via the reaction scheme outlined in Equations (22-24). The sulfuric acid vapor spontaneously nucleates particles or condenses on existing aerosol (modifying the size distribution of existing aerosol. We understand these processes as well as we do largely thanks to studies of the aftermath of a single eruption - that of Pinatubo (Republic of the Philippines) in 1991. The coincident emission of sulfur represented the largest perturbation to stratospheric aerosol abundance in decades and resulted in unambiguous atmospheric and climatic change. This section reviews what we have learned from the studies of the volcanic cloud and Earth system responses.

\section{Stratospheric $\mathrm{SO}_{2}$ cloud and sulfate formation.}

The first clear signs of unrest at Mt. Pinatubo were observed on 2 April 1991, when steam explosions occurred near the summit. Pinatubo had not previously been recognized as a potentially active volcano. On the afternoon of 15 June 1991, and following a crescendo in activity (Fig. 12), the volcano disgorged around $10 \mathrm{~km}^{3}$ of ash and pumice. Its magnitude, $M_{e}$, of 6.1 (based on the expression $M_{e}=\log _{10}($ mass of ejecta (in $\mathrm{kg})$ ) -7 ) makes it the largest eruption in a century (since that of Katmai in Alaska in 1912). 


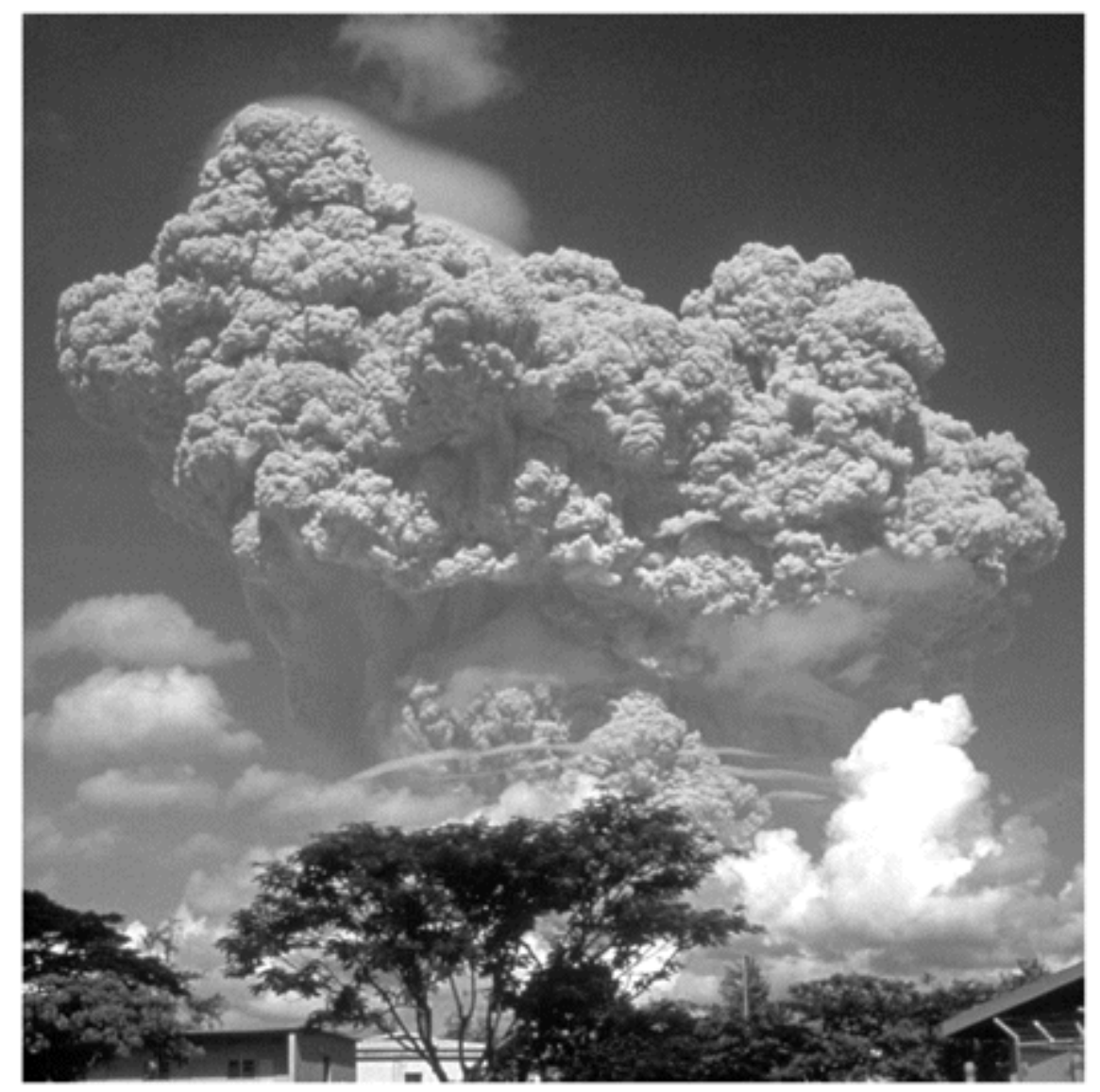

Figure 12. : Photograph of eighteen-km-high eruption plume of Mt. Pinatubo on 12 June 1991, three days before the climactic eruption. Photographed from Clark Air Base $(20 \mathrm{~km}$ east). Credit: Rick Hobblitt, US Geological Survey Cascades Volcano Observatory.

The stratosphere was reached both by the Plinian eruption column, and by co-ignimbrite clouds rising from pyroclastic currents. Due to the vast scale of Pinatubo's eruption plume, satellite observations were central in tracking its growth and dispersal around the globe. By 16:40 local time, the umbrella cloud forming in the stratosphere had attained a diameter of $500 \mathrm{~km}$. It covered an area of 300,000 $\mathrm{km}^{2}$ at 19:40 hours, and reached a maximum diameter of over $1100 \mathrm{~km}$ (Fig. 13). The umbrella cloud was $10-15 \mathrm{~km}$ thick and its top reached $35 \mathrm{~km}$ above sea level. Thirty-six hours after the start of the eruption, the cloud covered an area of $2.7 \times 10^{6} \mathrm{~km}^{2}$. By this stage the plume was travelling westsouthwest with the ash concentrated at an altitude of 16-18 km, and fallout occurring across the South China Sea. 
(a)

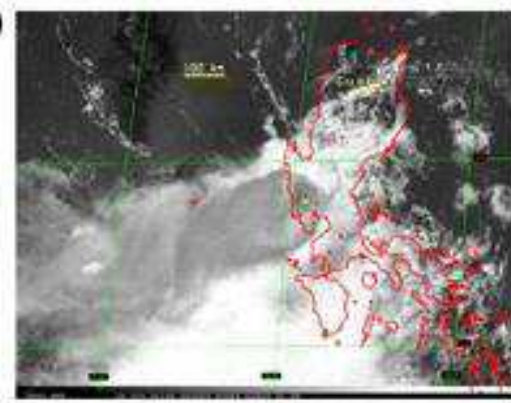

(c)

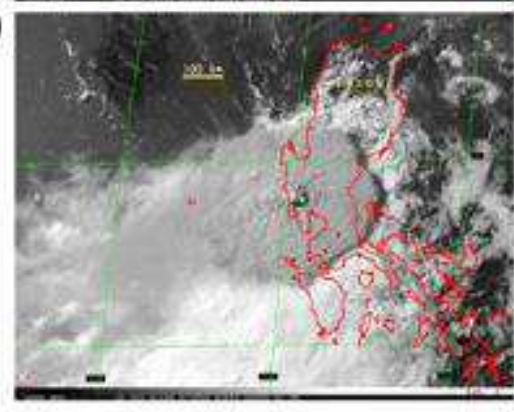

(b)

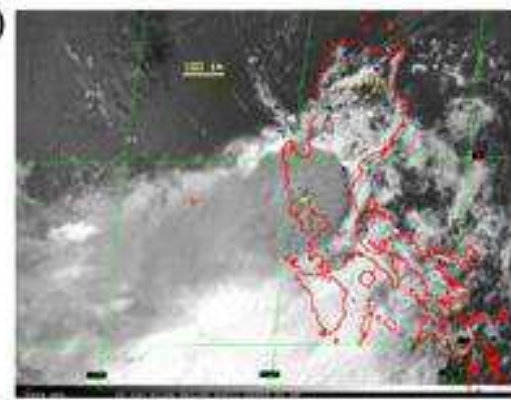

(d)

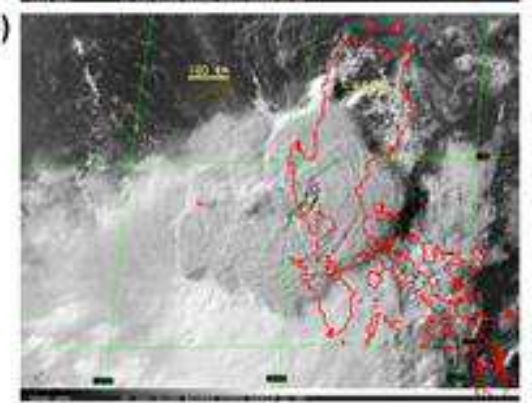

Figure 13. : Images of umbrella cloud of the 15-16 June, 1991 Mt. Pinatubo eruption, Philippines, as seen by the GMS weather satellite. The cross marks the volcano's location. (a) 13:31 local time, and the beginning of the climactic phase. The diameter of the umbrella cloud is about $90 \mathrm{~km}$. Ash is being transported southwest. The white cloud is associated with Typhoon Yunya; (b) 14:31, the umbrella cloud is expanding so fast it is propagating upwind as well as downwind at up to $70 \mathrm{~km} \mathrm{~h}^{-1}$; (c) 15:31, ash is being dispersed by winds to the southwest beneath the umbrella cloud; (d) 16:31, the umbrella cloud has reached its maximum diameter of over $1000 \mathrm{~km}$. Images processed by R.E. Holasek

(Holasek et al. 1996).

The best estimate yet published of the release of $\mathrm{SO}_{2}$ to the stratosphere is around $18 \mathrm{Tg}$ (or 9 Tg of S; Guo et al. 2004), which generated around $30 \mathrm{Tg}$ of sulfate aerosol. Ground-based lidar observations established that the bulk of Pinatubo's aerosol veil was at an altitude of 20$27 \mathrm{~km}$. Over the following months, the cloud expanded into both hemispheres though remaining trapped within a band between latitudes $30^{\circ} \mathrm{N}$ and $20^{\circ} \mathrm{S}$ through mid-1991. Strengthening of the Brewer-Dobson circulation eventually helped to mix the volcanic aerosol to higher latitudes.

\section{Stratospheric ozone depletion.}

Sulfate aerosol promotes numerous heterogeneous and multi-phase reactions that act in such a way as to shift stratospheric chlorine from stable compounds $\left(\mathrm{HCl}\right.$ and $\left.\mathrm{ClONO}_{2}\right)$ into more reactive ones (i.e., hypochlorous acid, $\mathrm{HOCl}$ ) that can destroy ozone. In theory, any increase in stratospheric $\mathrm{HO}_{x}, \mathrm{NO}_{x}, \mathrm{ClO}_{x}$ or $\mathrm{SO}_{x}$ could deplete stratospheric ozone levels. A few months after the Pinatubo eruption, global stratospheric ozone levels began to show a strong downturn. The clearest picture of the impacts was provided by the space-borne TOMS instrument (see section on satellite remote sensing above). Ozone levels, integrated through the depth of the atmosphere, decreased 6-8\% in the tropics in the first months after the eruption. These figures actually mask local depletions of up to $20 \%$ at altitudes of $24-25 \mathrm{~km}$. By mid-1992, ozone abundance in the stratosphere was lower than at any time in the preceding 12 years, reaching a low point in April 1993 when the global deficit was about 6\% compared with the average. Losses were greatest in the northern hemisphere: total column 
ozone above the USA dropped 10\% below average with the strongest depletion observed between 13 and $33 \mathrm{~km}$ altitude.

\section{Radiative and climatic impacts.}

The effects of stratospheric aerosol veils on electromagnetic radiation are highly complex (Fig. 14) because the haze can consist of variable proportions of very fine ash and sulfate aerosol of different compositions, sizes and shapes (and hence optical properties). The different components also accumulate and sediment out at different rates according to their masses and shapes, so that any effects on the Earth's heat budget can be expected to change through time. Once most of the gaseous sulfur has been converted, little more aerosol is formed and the total stratospheric aerosol load decreases as the particles subside into the troposphere, from which they are rapidly transferred to the surface by rainfall and other depositional processes. As the total aerosol burden decreases, the particle size distribution changes since larger particles have greater terminal velocities. As a result, the mean radius of the aerosol veil decreases over time.

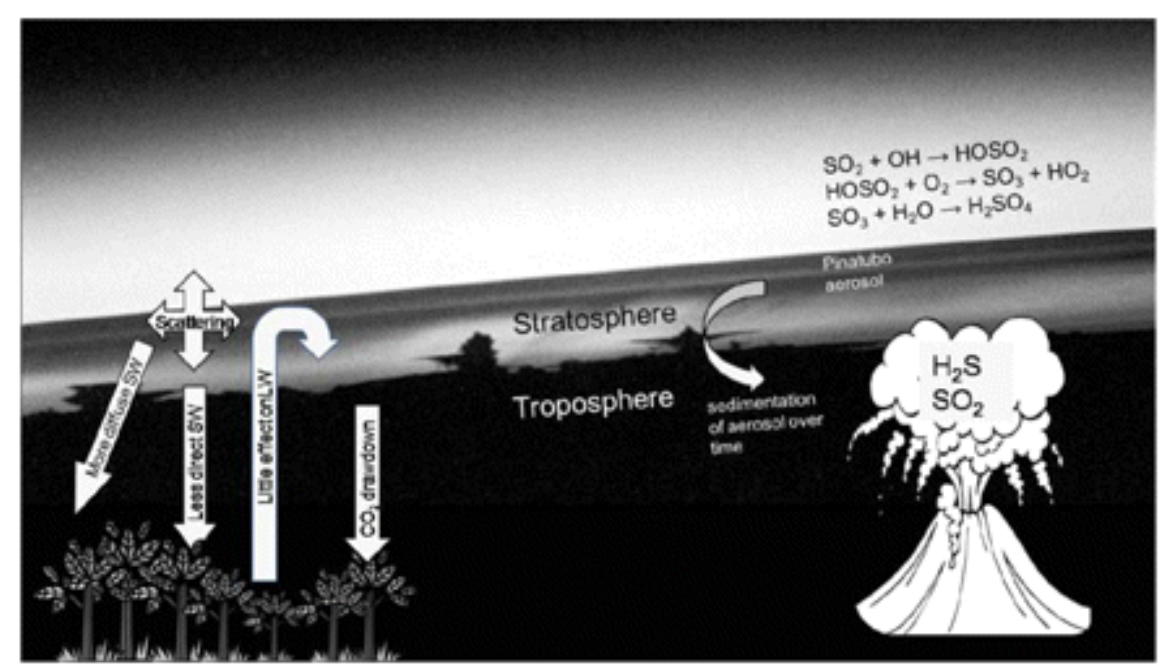

Figure 14. : Schematic diagram of the radiative effects of volcanic aerosol and some associated processes. The background photograph was taken from the Space Shuttle (mission STS 43) above central Africa and shows a double layer of aerosol generated after the 1991 eruption of Mt. Pinatubo. The layers are at heights of approximately 20 and $25 \mathrm{~km}$ above sea level. Photograph from the Image Science and Analysis Laboratory, NASA-JSC.

The particles scatter incoming shortwave radiation but can also absorb both upwelling and downwelling radiation. The net effect on the Earth's radiation budget is not straightforward to determine but, broadly, for warming to outbalance cooling, the aerosol's effective radius (a measure weighted by the particles' surface area) should exceed $2 \mu \mathrm{m}$. Prior to Pinatubo, the effective radius of stratospheric aerosol was about a tenth of this value. Pinatubo's contribution elevated the effective radius of stratospheric aerosol to about $0.5 \mu \mathrm{m}$.

Measures of the effects of the aerosol veil were obtained from the spaceborne Earth Radiation Budget Experiment (ERBE). By August 1991, ERBE revealed that the backscattering of solar radiation by the aerosol had increased the global albedo by around 5\% (Minnis et al. 1993; Wong et al. 2006). This corresponds to a deficit in direct sunlight of around 25-30\%, which 
was partly compensated for by an increase in the diffuse light from the sky. (Solar and sky measurements at the Mauna Loa Observatory, Hawai'i, indicated a decrease in the direct flux from about 520 to $400 \mathrm{~W} \mathrm{~m}^{-2}$, but an increase in the diffuse flux from 40 to $140 \mathrm{~W} \mathrm{~m}^{-2}$; Robock 2005). ERBE also revealed that the albedo increase was pronounced in normally "dark", cloud-free regions, including the Australian deserts and the Sahara, and in typically "bright" regions associated with deep convective cloud systems in the tropics including the Congo Basin. By July 1991, the outgoing shortwave flux increased dramatically over the tropics. This corresponded to a change in the net flux of up to $-8 \mathrm{~W} \mathrm{~m}^{-2}$ in August 1991, twice the magnitude of any other monthly anomaly. The net forcing for August 1991 amounted to $-4.3 \mathrm{~W} \mathrm{~m}^{-2}$ for the region between $40^{\circ} \mathrm{S}$ and $40^{\circ} \mathrm{N}$, indicating a globally averaged volcanic forcing of at least $-2.7 \mathrm{~W} \mathrm{~m}^{-2}$. The net flux returned to normal levels by March 1993.

Pinatubo's forcing effect on Earth's heat budget exceeded for two years the positive forcing due to anthropogenic greenhouse gases. The observed global cooling was initially rapid but punctuated by a warming trend, predominantly over northern land masses, between January and March 1992 (Parker et al. 1996). Cooling resumed and, by June 1992, amounted to about $0.5^{\circ} \mathrm{C}$. This figure hides much wider regional variations that included pockets of abnormally strong heating as well as cooling. For example, the Siberian winter was $5{ }^{\circ} \mathrm{C}$ warmer than normal, while the north Atlantic was $5{ }^{\circ} \mathrm{C}$ cooler than average. The overall cooling is also a fraction of a degree stronger if the warming effect of the prevailing El Niño is accounted for.

Globally, there was a significant drop in rainfall over land during the year following the eruption, making it the driest period in the half-century for which good records were available (Trenberth et al. 2007). However, there were strong regional patterns, including winter warming anomalies in Scandinavia, Siberia and central North America (Graf et al. 1993; Marshall et al. 2009; Stenchikov 2002). These temperature anomalies were associated with marked departures in sea-level pressure patterns in the first and second boreal winter associated with amplification of the positive phase of the North Atlantic Oscillation. This acts to transport warm, moist air to northern Eurasia.

The temperature and precipitation patterns following the Pinatubo eruption have been fitted reasonably well by Intergovernmental Panel on Climate Change (IPCC) models, though they reproduce the summer cooling better than the winter warming (Broccoli et al. 2003; Stenchikov et al. 2006; Thomas et al. 2009a,b). The reduced shortwave solar radiation falling on the sea surface resulted in a net deficit of $5 \times 10^{22} \mathrm{~J}$ in the surface ocean (Stenchikov et al. 2009). Globally averaged sea-surface temperatures dropped by around $0.4{ }^{\circ} \mathrm{C}$. This effect is now recognized for numerous earlier eruptions based on studies of corals and tree rings (D'Arrigo et al. 2009) and acts to lower sea level.

\section{Requirements for a climate-forcing eruption}

Based in large part on our understanding of the impacts of the 1991 Pinatubo eruption, it is possible to summarize a number of factors likely to distinguish an eruption capable of hemispheric to global scale climate impact (Oppenheimer 2011). We have seen that sulfur emission is crucial: it is the release of sulfur gases into the atmosphere during an eruption that leads to the formation of sulfate aerosol that may then perturb the Earth's heat budget. Thus the melt composition, sulfur content, redox state, eruption magnitude and so on, will play a large role in controlling the sulfur yield of an eruption (see section on geodynamics and geochemical behavior of sulfur above; Baker and Moretti 2011, this volume). However, the 
climate response does not scale in any simple way with the sulfur yield of an eruption. In particular, greater releases of sulfur lead to non-linearities in the Beer-Lambert relationship (Eqn. 15), limiting light scattering, and resulting in growth of larger particles that are less effective in scattering short-wave radiation $\left(\mathrm{H}_{2} \mathrm{SO}_{4}\right.$ vapor generated by oxidation of $\mathrm{SO}_{2}$ will tend to condense on existing particles rather than nucleate new small particles). They also settle out of the stratosphere more rapidly (Timmreck et al. 2009, 2010).

The injection height of sulfur into the atmosphere represents another important determinant of climate impact. More intense eruptions, i.e., those with higher magma discharge rates, are more likely to loft the reactive sulfur gases into the stratosphere where they can generate climatically effective aerosol. Co-ignimbrite clouds are capable of entraining material into the stratosphere, and have been responsible for some of the largest tephra fall deposits. However, little is known about their efficiency, compared with Plinian eruption columns, in injecting sulfur into the stratosphere. Differences in the dynamics of the two plume types may influence the transfer of sulfur to the stratosphere (Herzog et al. 2010).

The location of a volcano strongly influences the geographic distribution of atmospheric heating and the development of planetary waves that affect air circulation (especially in the northern hemisphere). Another relevant factor is that the height of the tropopause varies with latitude - at the tropics it is around 16-17 km above sea level but descends to $10-11 \mathrm{~km}$ at high latitudes. In general terms, an explosive eruption requires a greater intensity (magma discharge rate) to cross the tropopause in the tropics than at mid to polar latitudes. However, there are two factors that limit this effect. The first is that a high-latitude eruption will have a more limited effect than a low-latitude one because further from the tropics there is less solar energy to intercept. Secondly, atmospheric circulation works in a way to limit the effects of high latitude eruptions. A tropical eruption that pumps aerosol into the stratosphere results in localized heating. This increases the temperature difference in the middle atmosphere between the equator and high latitudes, and thereby enhances meridional air flows that spread aerosol into both hemispheres, promoting climate forcing at a worldwide scale. In contrast, volcanic aerosol injected into the stratosphere from high latitude volcanoes will tend to have the opposite effect on the temperature gradient, acting to stagnate meridional air flow. Very little, if any, of the stratospheric aerosol formed as a result of eruption of a high latitude volcano will reach the opposing hemisphere.

Nevertheless, both historical and modeling evidence suggests that high-latitude volcanic eruptions can have significant hemispheric climatic effects (Schneider et al. 2009). A climate model run for the 1912 Katmai eruption (Alaska), and the same event scaled up three times, confirmed pooling of the aerosol veil to high-boreal latitudes (Oman et al. 2005). It also suggested that radiative impacts should dominate over the effects on circulation of the atmosphere. However, the results of such modeling efforts are very sensitive to assumed sizes of aerosol and parameterizations of the microphysical processes that occur in clouds.

Linked to spatial influences on the climate forcing credentials of eruptions are seasonal considerations. These are likely to be most significant for high-latitude eruptions. With a strong polar vortex in winter, $\mathrm{SO}_{2}$ emissions could be trapped at high latitudes, and it would take longer to form sulfuric acid aerosol because of limited sunlight and oxidizing agents. One study that has explored seasonal influences on a mid-latitude eruption is the simulation of a super-eruption of $1700 \mathrm{Tg}$ of $\mathrm{SO}_{2}\left(100 \times\right.$ Pinatubo) from Yellowstone volcano $\left(44^{\circ} \mathrm{N}\right.$; Timmreck and Graf 2006). In the model, the aerosol veil of a summer eruption traveled west and southward, driven by the Aleutian high pressure system, compared with east and 
northward transport for a winter event, when westerlies dominate circulation. For the summertime case, more aerosol was transported to the southern hemisphere. This could be expected to exert a strong influence on radiative forcing at the Earth's surface.

\section{SUMMARY AND CONCLUSIONS}

Although this review has focused on sulfur, its behavior and impacts should always be regarded as part of a larger picture of chemical and physical interactions, notably in magmas where interactions with other volatile species are important. Nevertheless, sulfur is a truly remarkable element in its own right. Its behavior in magmatic, hydrothermal, volcanic, atmospheric, terrestrial and aquatic environments is complex owing to a range of factors including its important role in redox chemistry (and biogeochemistry). In the atmosphere, the oxidation of sulfur gases to sulfuric acid, either in the aqueous aerosol phase in the troposphere or via homogenous reactions in the stratosphere (with sulfuric acid condensing under the prevailing conditions), is of particular significance.

The short-term (months-to-years) impacts of volcanism on the atmosphere, climate and environment are strongly controlled by location, timing, flux, magnitude and emission height of sulfur gases (principally $\mathrm{SO}_{2}$ or $\mathrm{H}_{2} \mathrm{~S}$ depending strongly on the physical conditions of the magmatic source). Episodic explosive eruptions represent the principal perturbation to stratospheric aerosol (though the atmospheric effects of sulfur degassing associated with continental flood basalts might well be more profound). In the troposphere, the picture is less clear but a significant part of the global tropospheric sulfate burden may be volcanogenic. Sulfate aerosol influences the Earth's radiation budget by scattering and absorption of shortwave and long-wave radiation, and by acting as cloud condensation nuclei. When they are brought to the boundary layer and Earth's surface, clouds containing volcanic sulfur in both gaseous and aerosol phases can result in profound environmental and health impacts.

The global impacts of only one large eruption (magnitude $>10^{13} \mathrm{~kg}$ ) have been studied with any instrumental detail - the 1991 eruption of Mt. Pinatubo. As the twentieth anniversary of that event looms (at the time of writing), it is remarkable to note that new findings concerning its climatic, environmental and ecological consequences are still emerging. Despite the tremendous insights afforded by this event, it represents a very small sample of the range of volcanic eruption styles, geographic locations and atmospheric states that could combine to produce significant perturbations to atmospheric radiation and dynamics. An important issue is the readiness of the scientific community to record the next major climate-forcing eruption as effectively as possible. More generally, substantial further work is required to constrain the temporal and spatial distribution of gas and particle emissions (including sulfur, halogens and trace metal species) to the atmosphere from all erupting and dormant volcanoes. In addition to improved observational data on the spatial and temporal distributions of volcanic volatiles to the atmosphere, further studies are required to characterize the physical and chemical interactions of gases and particles in the atmosphere. This will be essential for the realistic application of numerical models describing the transport and chemical evolution of plumes, and will contribute to a better understanding of volcanogenic pollution and improved mitigation of its effects.

Surveillance of gas composition and flux are essential for interpretation of volcanic activity, since degassing is intimately linked with the physical and chemical environments of magma storage and the dynamics of magma transport. A revolution in spectroscopic and 
electrochemical techniques has taken place over the past decade providing greatly improved means for volcanic gas surveillance at all scales. In the near future, we can anticipate further revolutions in the ability to measure volcanic volatile emissions in the field thanks to current developments of laser spectroscopy and lidar systems (enabling in situ determination of isotopic compositions of $\mathrm{C}, \mathrm{O}, \mathrm{H}, \mathrm{S}, \mathrm{Cl}$, etc., and remote measurement of $\mathrm{CO}_{2}$ fluxes). Satellite remote sensing methods and the use of unmanned aerial vehicles will also lead to improved measurements of volcanic plumes and better inventories of the temporal and spatial distribution of sulfur (and carbon and halogen) fluxes. Unfortunately, the modeling frameworks for interpretation of geochemical data remain underdeveloped, impeding the application of such data in hazard assessment. Advances in this area will benefit from development and validation of comprehensive physico-chemical models for volcanic degassing and associated magma storage and transport based on the integration of results from experiments on the controls on distribution of volatiles in synthetic and natural melts (with an emphasis on understanding redox controls), analysis of dissolved volatiles preserved in melt inclusions, and observed volcanic gas geochemistry. Ultimately, such models can be applied

to integrated inversions of geophysical, geodetic and geochemical monitoring data to support hazard assessment.

\section{Acknowledgments}

We thank Tobias Fischer, Mike Burton and Jim Webster for their careful and constructive reviews of the original manuscript. CO acknowledges support from the NERC via the National Centre for Earth Observation ("Dynamic Earth" theme) and the project "Magma dynamics at persistently degassing basaltic volcanoes: a novel approach to linking volcanic gases and magmatic volatiles within a physical model", the European Research Council (for the DEMONS project "Deciphering eruptions by modeling outputs of natural systems"), and the EC $7^{\text {th }}$ Framework Programme for support via the MIAVITA project "Mitigate and assess risk from volcanic impact on terrain and human activities." Le Studium Institute for Advanced Studies receives support from the European Regional Development Fund. 


\section{REFERENCES}

Aiuppa A, Baker DR, Webster JD (2009) Halogens in volcanic systems. Chem Geol 263:1-18

Aiuppa A, Bellomo S, Brusca L, D'Alessandro W, Di Paola R, Longo M (2006) Major-ion bulk deposition around an active volcano (Mt Etna, Italy). Bull Volcanol 68:255-265

Aiuppa A, Bellomo S, D'Alessandro W, Federico C, Ferm M, Valenza M (2004) Volcanic plume monitoring at Mount Etna by diffusive (passive) sampling. J Geophys Res 109, doi:101029/2003JD004481

Aiuppa A, Bertagnini A, Métrich A, Moretti R, Di Muro A, Liuzzo A, Tamburello G (2010) A model of degassing for Stromboli volcano. Earth Planet Sci Lett 295:195-204

Aiuppa A, Federico C, Giudice G, Gurrieri S (2005a) Chemical mapping of a fumarolic field: La Fossa Crater, Vulcano Island (Aeolian Islands, Italy). Geophys Res Lett 32, doi:101029/2005GL023207

Aiuppa A, Inguaggiato S, McGonigle AJS, O'Dwyer M, Oppenheimer C, Padgett MJ, Rouwet D, Valenza $M(2005 b) H_{2} S$ fluxes from Mt Etna, Stromboli and Vulcano (Italy) and implications for the global volcanic sulfur budget. Geochim Cosmochim Acta 69:1861-1871

Aiuppa A, Moretti R, Federico C, Giudice G, Gurrieri S, Liuzzo M, Papale P, Shinohara H, Valenza M (2007a) Forecasting Etna eruptions by real-time observation of volcanic gas composition. Geology 35:1115-118

Aiuppa A, Franco A, von Glasow R, Allen AG, D'Alessandro W, Mather TA, Pyle DM, Valenza M (2007b) The tropospheric processing of acidic gases and hydrogen sulphide in volcanic gas plumes as inferred from field and model investigations. Atmos Chem Phys 7:1441-1450

Allard $\mathrm{P}(1979){ }^{13} \mathrm{C} /{ }^{12} \mathrm{C}$ and ${ }^{34} \mathrm{~S} /{ }^{32} \mathrm{~S}$ ratios in magmatic gases from ridge volcanism in Afar. Nature 282:56-58

Allard P (1981) Stable isotope composition of hydrogen, carbon and sulphur in magmatic gases from rift and island arc volcanoes. Bull Volcanol 45:269-271

Allard P (1997) Endogeneous magma degassing and storage at Mount Etna. Geophys Res Lett 24:2219-2222

Allard P (2010) A $\mathrm{CO}_{2}$-rich gas trigger of explosive paroxysms at Stromboli basaltic volcano, Italy. J Volcanol Geoth Res 189:363-374

Allard P, Burton M, Muré F (2005) Spectroscopic evidence for a lava fountain driven by previously accumulated magmatic gas. Nature 433:407-410

Allard P, Carbonnelle J, Dajlevic D, Le Bronec J, Morel P, Robe MC, Maurenas JM, Faivre-Pierret R, Martin D, Sabroux JC, Zettwoog $P$ (1991) Eruptive and diffuse emissions of $\mathrm{CO}_{2}$ from Mount Etna. Nature 351:387-390 
Allard P, Carbonnelle J, Métrich N, Loyer H, Zettwoog P (1994) Sulphur output and magma degassing budget of Stromboli volcano. Nature 368:326-329

Allard P, Le Guern F, Sabroux JC (1977) Themodynamic and isotopic studies in eruptive gases. Geothermics 5:37-40

Allen AG, Baxter PJ, Ottley CJ (2000) Gas and particle emissions from Soufrière Hills volcano, Montserrat, WI: Characterization and health hazard assessment. Bull Volcanol 62:6-17

Allen AG, Mather TA, McGonigle AJS, Aiuppa A, Delmelle P, Davison B, Bobrowski N, Oppenheimer C, Pyle DM, Inguaggiato $S$ (2006) Sources, size distribution, and downwind grounding of aerosols from Mount Etna. J Geophys Res 111, doi:101029/2005JD006015

Allen AG, Oppenheimer C, Ferm M, Baxter PJ, Horrocks L, Galle B, McGonigle AJS, Duffell HJ (2002) Primary sulphate aerosol and associated emissions from Masaya volcano, Nicaragua. J Geophys Res, doi 101029/2002JD002120

Amend JP, Shock EL (2001) Energetics of overall metabolic reactions in thermophilic and hyperthermophilic Archaea and bacteria FEMS. Microbiol Rev 25:175-243

Anderson AT, Newman S, Williams SN, Druitt TH, Skirius C, Stolper E (1989) $\mathrm{H}_{2} \mathrm{O}, \mathrm{CO}_{2}$, Cl gas in Plinian and ash-flow Bishop rhyolite. Geology 17:221-225

Andres RJ, Kasgnoc AD (1998) A time-averaged inventory of subaerial volcanic sulfur emissions. J Geophys Res 103(D19):25,251-25,261

Andres RJ, Rose WI, Kyle PR, DeSilva S, Francis P, Gardeweg M, Moreno Roa H (1991) Excessive sulfur dioxide emissions from Chilean volcanoes. J Volcanol Geotherm Res 46:323-329

Arellano S, Hall M, Samaniego P, Le Pennec J-L, Ruiz A, Molina I, Yepes H (2008) Degassing patterns of Tungurahua volcano (Ecuador) during the 1999-2006 eruptive period, inferred from remote spectroscopic measurements of $\mathrm{SO}_{2}$ emissions. J Volcanol Geotherm Res 176:151-162

Bagnato E, Aiuppa A, Parello F, Calabrese S, D'Alessandro W, Mather TA, McGonigle AJS, Pyle DM, Wängberg I (2007) Degassing of gaseous (elemental and reactive) and particulate mercury from Mount Etna volcano (Southern Italy). Atmos Env 41:7377-7388

Baillie MGL (2010) Volcanoes, ice-cores and tree rings: one story or two? Antiquity 84:202-215

Baker DR, Moretti R (2011) Modeling the solubility of sulfur in magmas: a 50-year old geochemical challenge. Rev Mineral Geochem 73:167-213

Ballhaus C (1993) Redox states of lithospheric and asthenospheric upper mantle. Contrib Mineral Petrol 114: 331-348

Bani P, Oppenheimer C, Tsanev VI, Carn SA, Cronin SJ, Crimp R, Calkins JA, Charley D, Lardy M Roberts $T R$ (2009) Surge in sulphur and bromine degassing from Ambrym volcano, Vanuatu. Bull Volcanol 71:1159-1168 
Baxter PJ (2000) Impacts of eruptions on human health. In: Encyclopedia of volcanoes. Sigurdsson $H$, Houghton BF, McNutt SR, Rymer H, Stix J (eds) Academic Press, San Diego, p 1035-1043

Baxter PJ, Stoiber RE, Williams SN (1982) Volcanic gases and health: Masaya Volcano, Nicaragua. Lancet 2:150-151

Behrens $\mathrm{H}$, Ohlhorst $\mathrm{S}$, Holtz $\mathrm{F}$, Champenois $\mathrm{M}$ (2004) $\mathrm{CO}_{2}$ solubility in dacitic melts equilibrated with $\mathrm{H}_{2} \mathrm{O}-\mathrm{CO}_{2}$ fluids: Implications for modelling the solubility of $\mathrm{CO}_{2}$ in silicic melts. Geochim Cosmochim Acta 68:4687-4703

Berresheim H, Jaeschke W (1983) The contribution of volcanoes to the global atmospheric sulfur budget. J Geophys Res 88(C6):3732-3740

Bertagnini A, Métrich N, Francalanci L, Landi P, Tommasini S, Conticelli S (2008) Volcanology and magma geochemistry of the present-day activity: constraints on the feeding system. In: Learning from Stromboli. Calvari S, Inguaggiato S, Puglisi G, Ripepe M, Rosi M (eds) Am Geophys Union, Geophys Mon 182:19-38

Bertagnini A, Métrich N, Landi P, Rosi M (2003) Stromboli volcano (Aeolian Archipelago, Italy): an open window on the deep-feeding system of a steady state basaltic volcano. J Geophys Res 108(B7): 2336, doi:101029/2002JB002146

Bézos A, Humler E (2002) The $\mathrm{Fe}^{3+} / \Sigma \mathrm{Fe}$ ratios of MORB glasses and their implications for mantle melting. Geochim Cosmochim Acta 69:711-725

Bhugwant C, Sieja B, Bessafi M, Staudacher T, Ecormier J (2009) Atmospheric sulfur dioxide measurements during the 2005 and 2007 eruptions of the Piton de La Fournaise volcano: Implications for human health and environmental changes. J Volcanol Geotherm Res 184:208-224

Blake S (2003) Correlations between eruption magnitude, $\mathrm{SO}_{2}$ yield, and surface cooling. In: Volcanic Degassing. Oppenheimer C, Pyle DM, Barclay J (eds) Special Publication of the Geological Society of London 213:177-202

Bluth G, Shannon JM, Watson IM, Prata AJ, Realmuto VJ (2007) Development of an ultra-violet digital camera for volcanic $\mathrm{SO}_{2}$ imaging. J Volcanol Geotherm Res 161:47-56

Bluth GJS, Carn SA (2008) Exceptional sulphur degassing from Nyamuragira volcano, 1979-2005. Int J Remote Sens 29:6667-6685

Bluth GJS, Casadevall TJ, Schnetzler CC, Doiron SD, Walter LS, Krueger AJ, Badruddin M (1994)

Evaluation of sulfur dioxide emissions from explosive volcanism: the 1982-1983 eruptions of Galunggung, Java, Indonesia. J Volcanol Geotherm Res 63:243-256

Bluth GJS, Rose WI, Sprod IE, Krueger AJ (1997) Stratospheric loading of sulfur from explosive volcanic eruptions. J Geol 105:671-684

Bobrowski N, Honninger G, Galle B, Platt U (2003) Detection of bromine monoxide in a volcanic plume. Nature 423:273-276 
Bobrowski N, Platt U (2007) $\mathrm{SO}_{2} / \mathrm{BrO}$ ratios studied in five volcanic plumes. J Volcanol Geotherm Res 166:147-160

Bobrowski N, von Glasow R, Aiuppa A, Inguaggiato S, Louban I, Ibrahim OW, Platt U (2007) Reactive halogen chemistry in volcanic plumes. J Geophys Res 112:D06311, doi:101029/2006JD007206

Boichu M, Oppenheimer C, Tsanev V, Kyle PR (2010) High temporal resolution $\mathrm{SO}_{2}$ flux measurements at Erebus volcano, Antarctica. J Volcanol Geotherm Res 190:325-336

Boichu M, Oppenheimer C, Tsanev V, Kyle PR (2011) On bromine, nitrogen oxides and ozone depletion in the tropospheric plume of Erebus volcano (Antarctica). Atmos Env doi:10.1016/j.atmosenv.2011.03.027

Botcharnikov RE, Behrens H, Holtz F, Koepke J, Sato H (2004) Sulfur and chlorine solubility in Mt Unzen rhyodacitic melt at $850^{\circ} \mathrm{C}$ and 200 MP. Chem Geol 213:207-225

Broccoli AJ, Dixon KW, Delworth TL, Knutson TR, Stouffer RJ, Zeng F (2003) Twentieth-century temperature and precipitation trends in ensemble climate simulations including natural and anthropogenic forcing. J Geophys Res 108(D24):4798, doi:101029/2003JD003812

Bureau H, Métrich N, Semet MP, Staudacher T (1999) Fluid-magma decoupling in a hot spot volcano. Geophys Res Lett 26:3501-3504

Bureau H, Pineau F, Métrich N, Semet M, Javoy M (1998) A melt and fluid inclusion study of the gas phase at Piton de la Fournaise volcano (Réunion Island). Chem Geol 147:115-130

Burgisser A, Scaillet B (2007) Redox evolution of a degassing magma rising to the surface. Nature 445:194-197

Burgisser A, Scaillet B, Harshvardhan (2008) Chemical patterns of erupting silicic magmas and their influence on the amount of degassing during ascent. J Geophys Res 113:B12204, doi:101029/2008JB005680

Burton M, Allard P, Murè F, La Spina A (2007a) Magmatic gas composition reveals the source depth of slug-driven Strombolian explosive activity. Science 317:227-230

Burton MR, Caltabiano T, Murè F, Randazzo D (2009) $\mathrm{SO}_{2}$ flux from Stromboli during the 2007 eruption: Results from the FLAME network and traverse measurements. J Volcanol Geotherm Res $182: 214-220$

Burton MR, Mader HM, Polacci M (2007b) The role of gas percolation in quiescent degassing of persistently active basaltic volcanoes. Earth Planet Sci Lett 264:46-60

Caltabiano $T$, Romano R, Budetta $G$ (1994) $\mathrm{SO}_{2}$ flux measurements at Mount Etna (Sicily). J Geophys Res 99:12,809-12,819

Campion R, Salerno GG, Coheur P-F, Hurtmans D, Clarisse L, Kazahaya K, Burton M, Caltabiano T, Clerbaux $C$, Bernard A (2010) Measuring volcanic degassing of $\mathrm{SO}_{2}$ in the lower troposphere with ASTER band ratios. J Volcanol Geotherm Res 194:42-54 
Camuffo D, Enzi S (1995) Impact of clouds of volcanic aerosols in Italy during the last seven centuries. Nat Hazards 11(2):135-161

Carmichael ISE (1991) The redox state of basic and silicic magmas: a reflection of their source regions? Contrib Mineral Petrol 106:129-141

Carn SA (2004) Eruptive and passive degassing of sulphur dioxide at Nyiragongo Volcano (D. $R$. Congo): the 17th January 2002 eruption and its aftermath. Acta Vulcanol 14(15):75-86

Carn SA, Krueger AJ, Bluth GJS, Schaefer SJ, Krotkov NA, Watson IM, Datta S (2003) Volcanic eruption detection by the Ozone Mapping Spectrometer (TOMS) instruments: a 22-year record of sulphur dioxide and ash emissions. In: Volcanic Degassing. Oppenheimer C, Pyle DM, Barclay J (eds) Geol Soc Lond Spec Pub 213:177-202

Carn SA, Krueger AJ, Krotkov NA, Yang K, Evans K (2009) Tracking volcanic sulfur dioxide clouds for aviation hazard mitigation. Nat Hazards 51:325-343

Casadevall TJ, Doukas MP, Neal CA, McGimsey RG, Gardner CA (1994) Emission rates of sulfur dioxide and carbon dioxide from Redoubt Volcano during the 1989-1990 eruptions. J Volcanol Geotherm Res 62:519-530

Casadevall TJ, Rose WI Jr, Fuller WH, Hunt WH, Hart MA, Moyers JL, Woods DC, Chuan RL, Friend JP (1984) Sulfur dioxide and particles in quiescent volcanic plumes from Poás, Arenal, and Colima volcanos, Costa Rica and Mexico. J Geophys Res 89(D6):9633-9641

Castrillo A, Casa G, Burgel MV, Tedesco D, Gianfrani L (2004) First field determination of the ${ }^{13} C^{12} C$ isotope ratio in volcanic $\mathrm{CO}_{2}$ by diode-laser spectrometry. Opt Express 12:651

- Chesner CA, Luhr JF (2010) A melt inclusion study of the Toba Tuffs, Sumatra, Indonesia. J Volcanol Geotherm Res 197:259-278

Chin M, Jacob DJ (1996) Anthropogenic and natural contributions to tropospheric sulfate: a global model analysis. J Geophys Res 101:18691-18699

Chow DC, Grandinetti A, Fernandez E, Sutton AJ, Elias T, Brooks B, Tam EK (2010) Is volcanic air pollution associated with decreased heart-rate variability? Heart Asia 2:36-41

Christensen LE, Brunner B, Truong KN, Mielke RE, Webster CR, Coleman M (2007) Measurement of sulfur isotope compositions by tunable laser spectroscopy of $\mathrm{SO}_{2}$. Anal Chem 79:9261-9268

Christie DM, Carmichael ISE, Langmuir CH (1986) Oxidation states of mid-ocean ridge basalt glasses. Earth Planet Sci Lett 79:397-411

Clemente B, Scaillet B, Pichavant M (2004) The solubility of sulphur in rhyolitic melts. J Petrol 45:2171-2196

Clerbaux C, Coheur P-F, Clarisse L, Hadji-Lazaro J, Hurtmans D, Turquety S, Bowman K, Worden H, Carn SA (2008) Measurements of $\mathrm{SO}_{2}$ profiles in volcanic plumes from the NASA Tropospheric Emission Spectrometer (TES). Geophys Res Lett 35:L22807, doi:101029/2008GL035566 
Corradini S, Merucci L, Prata AJ (2009) Retrieval of $\mathrm{SO}_{2}$ from thermal infrared satellite measurements: correction procedures for the effects of volcanic ash. Atmos Meas Tech 2:177-191

Costa F, Scaillet B, Gourgaud A (2003) Massive atmospheric sulfur loading of the AD 1600

Huaynaputina eruption and implications for petrologic sulfur estimates. Geophys Res Lett 30(2):1068, doi:101029/2002GL016402

Costa F, Scaillet B, Pichavant M (2004) Petrological and experimental constraints on the pre-eruption conditions of Holocene dacite from Volcán San Pedro (36 ${ }^{\circ}$, Chilean Andes) and the importance of sulphur in silicic subduction-related magmas. J Petrol 45:855-881

Cottrell E, Gardner J, Rutherford MJ (1999) Petrologic and experimental evidence for the movement and heating of the pre-eruptive Minoan rhyodacite (Santorini, Greece). Contrib Mineral Petrol 135:315-331

Courtillot VE, Renne PR (2003) On the ages of flood basalt events. C R Geosci 335:113-140

$D^{\prime}$ Arrigo $R$, Wilson $R$, Tudhope A (2009) The impact of volcanic forcing on tropical temperatures during the past four centuries. Nature Geosci 2:51-56

Daag AS, Tubianosa BS, Newhall CG, Tuñgol NM, Javier D, Dolan MT, Delos Reyes PJ, Arboleda RA, Martinez ML, Regalado TM (1996) Monitoring sulfur dioxide emission at Mount Pinatubo. In: Fire and mud: eruptions and lahars of Mount Pinatubo Philippines. Newhall CG, Punongbayan RS (eds), Philippine Institute of Volcanology and Seismology, Quezon City, and University of Washington Press, Seattle. $p$ 409-434

Dalton MP, Waite GP, Watson IM, Nadeau PA (2010) Multiparameter quantification of gas release during weak Strombolian eruptions at Pacaya Volcano, Guatemala. Geophys Res Lett 37:L09303, doi:101029/2010GL042617

de Foy B, Krotkov NA, Bei N, Herndon SC, Huey LG, Martínez A-P, Ruiz-Suárez LG, Wood EC, Zavala M, Molina LT (2009) Hit from both sides: tracking industrial and volcanic plumes in Mexico City with surface measurements and $\mathrm{OMI} \mathrm{SO}_{2}$ retrievals during the MILAGRO field campaign. Atmos Chem Phys 9:9599-9617

de Moor JM, Fischer TP, Hilton DR, Hauri E, Jaffe LA, Camacho JT (2005) Degassing at Anatahan volcano during the May 2003 eruption: Implications from petrology, ash leachates, and $\mathrm{SO}_{2}$ emissions. J Volcanol Geotherm Res 146:117-138

de Moor JM, Fischer TP, Sharp ZD, Hauri EH, Hilton DR, Atudorei V (2010) Sulfur isotope fractionation during the May 2003 eruption of Anatahan volcano, Mariana Islands: Implications for sulfur sources and plume processes. Geochim Cosmochim Acta 74:5382-5397

De Vito S, Massera E, Quercia L, Di Francia G (2007) Analysis of volcanic gases by means of electronic nose. Sensors Actuators 127: 36-41

Delgado-Granados H, González LC, Sánchez NP (2001) Sulfur dioxide emissions from Popocatépetl volcano (Mexico): case study of a high-emission rate, passively degassing erupting volcano. J Volcanol Geotherm Res 108:107-120 
Delmelle P, Delfosse T, Delvaux B (2003) Sulfate, chloride and fluoride retention in Andosols exposed to volcanic acid emissions. Environ Pollut 126:445-457

Delmelle P, Stix J, Baxter P, Garcia-Alvarez J, Barquero J (2002) Atmospheric dispersion, environmental effects and potential health hazard associated with the low altitude gas plume of Masaya volcano, Nicaragua. Bull Volcanol 64:423-434

Delmelle P, Stix J, Bourque CPA, Baxter P, Garcia-Alvarez J, Barquero J (2001) Dry deposition and heavy acid loading in the vicinity of Masaya volcano, a major sulfur and chlorine source in Nicaragua. Environ Sci Technol 7:1289-1293

Di Carlo I, Pichavant M, Rotolo SG, Scaillet B (2006) Experimental crystallization of a high-K arc basalt: The golden pumice, Stromboli volcano (Italy). J Petrol 47(7):1317-1343

Diaz JA, Giese CF, Gentry WR (2002) Mass spectrometry for in-situ volcanic gas monitoring. Trends Anal Chem 21:498-514

Diehl T (2009) A global inventory of volcanic $\mathrm{SO}_{2}$ emissions for hindcast scenarios. http://wwwIscedods.cea.fr/aerocom/AEROCOM_HC/volc/

Dixon JE, Clague DA (2001) Volatiles in basaltic glasses from Loihi seamount, Hawaii: evidence for a relatively dry plume component. J Petrol 42:627-654

Dixon JE, Clague DA, Stolper E (1991) Degassing history of water, sulfur, and carbon in submarine lavas from Kilauea volcano, Hawaii. J Geol 99:371-394

Dixon JE, Clague DA, Wallace P, Poreda R (1997) Volatiles in alkalic basalts from the North Arch volcanic field, Hawaii: extensive degassing of deep submarine-erupted alkalic series lavas. J Petrol 38:911-939

Dixon JE, Stolper E, Delaney JR (1988) Infrared spectroscopic measurements of $\mathrm{CO}_{2}$ and $\mathrm{H}_{2} \mathrm{O}$ in Juan de Fuca Ridge basaltic glasses. Earth Planet Sci Lett 90:87-104

Dixon JE, Stolper EM, Holloway JR (1995) An experimental study of water and carbon dioxide solubilities in mid-ocean ridge basaltic liquids Part I: Calibration and solubility models J Petrol 36:1607-1631

Doutriaux-Boucher M, Dubuisson P (2008) Detection of volcanic $\mathrm{SO}_{2}$ by spaceborne infrared radiometers. Atmos Res 92:69-79

Eatough DJ, Caka FM, Farber RJ (1994) The conversion of $\mathrm{SO}_{2}$ to sulfate in the atmosphere. Isr J Chem 34:301-314

Eckhardt S, Prata AJ, Seibert P, Stebel K, Stohl A (2008) Estimation of the vertical profile of sulfur dioxide injection into the atmosphere by a volcanic eruption using satellite column measurements and inverse transport modeling. Atmos Chem Phys 8:3881-3897 
Edmonds M, Herd RA, Galle B, Oppenheimer C (2003a) Automated, high time-resolution measurements of $\mathrm{SO}_{2}$ flux at Soufrière Hills Volcano, Montserrat. Bull Volcanol 65:578-586

Edmonds M, Oppenheimer C, Pyle DM, Herd R (2003b) Rainwater and ash leachate analysis as a proxy for plume chemistry at Soufrière Hills Volcano, Montserrat. In: Volcanic degassing. Geol Soc Spec Pub 213:203-218

Edmonds M, Oppenheimer C, Pyle DM, Herd RA, Thompson G (2003c) $\mathrm{SO}_{2}$ emissions from Soufrière Hills Volcano and their relationship to conduit permeability, hydrothermal interaction and degassing regime. J Volcanol Geotherm Res 124:23-43

Edner H, Ragnarson S, Svanberg S, Wallinder E, Ferrera R, Cioni R, Raco B, Taddeucci G (1994) Total fluxes of sulfur dioxide from the Italian Volcanoes Etna, Stromboli and Vulcano measured by differential absorption lidar and passive differential optical absorption spectroscopy. J Geophys Res 99:18827-18838

Elias T, Sutton AJ, Oppenheimer C, Horton KA, Garbeil H, Tsanev V, McGonigle AJS, Williams-Jones G (2006) Intercomparison of COSPEC and two miniature ultraviolet spectrometer systems for $\mathrm{SO}_{2}$ measurements using scattered sunlight. Bull Volcanol 68:313-322

EPICA Community Members (2004) Eight glacial cycles from an Antarctic ice core. Nature 429:623628

Ferguson DJ, Barnie TD, Pyle DM, Oppenheimer C, Yirgu G, Lewi E, Kidane T, Carn S, Hamling I (2010) Recent rift-related volcanism in Afar, Ethiopia. Earth Planet Sci Lett 292:409-418

Ferry JM, Baumgartner L (1987) Thermodynamic models of molecular fluids at the elevated pressures and temperatures of crustal metamorphism. Rev Mineral 17:323-365

Fischer TP, Morrissey MM, Calvache ML, Gómez M, Torres R, Stix J, Williams SN (1994) Correlations between $\mathrm{SO}_{2}$ flux and long-period seismicity at Galeras volcano. Nature 368:135-137

Fischer TP (2008) Volatile fluxes $\left(\mathrm{H}_{2} \mathrm{O}, \mathrm{CO}_{2}, \mathrm{~N}_{2}, \mathrm{HCl}, \mathrm{HF}\right)$ from arc volcanoes. Geochem J 42:21-38

Francis $P$, Burton M, Oppenheimer C (1998) Remote measurements of volcanic gas compositions by solar FTIR spectroscopy. Nature 396:567-570

Francis $P$, Maciejewski A, Oppenheimer C, Chaffin C, Caltabiano $\mathrm{T}(1995) \mathrm{SO}_{2}: \mathrm{HCl}$ ratios in the plumes from Mt Etna and Vulcano determined by Fourier transform spectroscopy. Geophys Res Lett 22:17171720

Francis PW, Oppenheimer C, Stevenson D (1993) Endogenous growth of persitently active volcanoes. Nature 366:554-557

Fujita S, Sakurai T, Matsuda K (2003) Wet and dry deposition of sulfur associated with the eruption of Miyakejima volcano, Japan. J Geophys Res 108(D15):4444, doi:101029/2002JD003064

Gaillard F, Scaillet B (2009) The sulfur content of volcanic gases on Mars. Earth Planet Sci Lett 279:3443 
Galle B, Johansson M, Rivera C, Zhang Y, KihIman M, Kern C, Lehmann T, Platt U, Arellano S, Hidalgo S (2010) Network for Observation of Volcanic and Atmospheric Change (NOVAC)-A global network for volcanic gas monitoring: Network layout and instrument description. J Geophys Res 115:D05304, doi:101029/2009JD011823

Galle B, Oppenheimer C, Geyer A, McGonigle A, Edmonds M, Horrocks LA (2003) A miniaturised ultraviolet spectrometer for remote sensing of $\mathrm{SO}_{2}$ fluxes: a new tool for volcano surveillance, $J$ Volcanol Geotherm Res 119:241-254

Gao C, Oman L, Robock A, Stenchikov GL (2007) Atmospheric volcanic loading derived from bipolar ice cores: Accounting for the spatial distribution of volcanic deposition. J Geophys Res 112:D09109, doi:101029/2006JD007461

Gao C, Robock A, Ammann C (2008) Volcanic forcing of climate over the past 1500 years: An improved ice core-based index for climate models. J Geophys Res 113, D23111, doi:101029/2008JD010239

Gassó S (2008) Satellite observations of the impact of weak volcanic activity on marine clouds. J Geophys Res 113:D14S19, doi:101029/2007JD009106

Gerlach T (2004b) Volcanic sources of troposphere ozone-depleting trace gases. Geochem Geophys Geosyst 5:Q09007, doi:10.1029/2004GC000747

Gerlach TM (1979) Evaluation and restoration of the 1970 volcanic gas analyses from Mount Etna, Sicily. J Volcanol Geotherm Res 6:165-178

Gerlach TM (1980) Investigation of volcanic gas analyses and magma outgassing from Erta 'Ale lava lake, Afar, Ethiopia. J Volcanol Geotherm Res 7:415-441

Gerlach TM (1993) Oxygen buffering of Kilauea volcanic gases and the oxygen fugacity of Kilauea basalt. Geochim Cosmochim Acta 57:795-814

Gerlach TM (2004a) Comment on paper: "Morphology and compositions of spinel in Pu'u'O'o lava (1996-1998), Kilauea volcano, Hawaii-enigmatic discrepancies between lava and gas-based $f_{02}$ determinationsof Pu'u'O'o lava. J Volcanol Geotherm Res 134:241-244

Gerlach TM, Casadevall TJ (1986) Evaluation of gas data from high temperature fumaroles at Mount St Helens, 1980-1982. J Volcanol Geotherm Res 28:107-140

Gerlach TM, McGee KA (1994) Total sulfur dioxide emissions and pre-eruption vapor saturated magma at Mount St Helens, 1980-88. Geophys Res Lett 21(25):2833-2836

Gerlach TM, Nordlie BE (1975) The C-O-H-S gaseous system Part II: Temperature, atomic composition and molecular equilibria in volcanic gases. Am J Sci 275:377-394

Gerlach TM, Westrich HR, Casadevall TJ, Finnegan DL (1994) Vapor saturation and accumulation in magmas of the 1989-1990 eruption of Redoubt volcano, Alaska. J Volcanol Geotherm Res 62:317-37

Gerlach TM, Westrich HR, Symonds RB (1996) Pre-eruption vapor in magma of the climactic Mount Pinatubo eruption: source of the giant stratospheric sulfur dioxide cloud. In: Newhall CG, 
Punongbayan RS (eds) Fire and Mud Eruptions and Lahars of Mount Pinatubo, Philippines, University of Washington Press, $p$ 415-434

Gianfrani L, De Natale P, De Natale G (2000) Remote sensing of volcanic gases with a DFB-laser-based fiber spectrometer. Appl Phys B 70:467-470

Gianfrani L, Gagliardi G, van Burgel M, Kerstel E (2003) Isotope analysis of water by means of nearinfrared dual-wavelength diode laser spectroscopy. Opt Express 11(13):1566-1576

Giggenbach WF (1975) A simple method for the collection and analysis of volcanic gas samples. Bull Volcanol 39: 132-145

Giggenbach WF (1987) Redox processes governing the chemistry of fumarolic gas discharges from White Island, New Zealand. Appl Geochem 1987(2):143-161

Giggenbach WF (1996) Chemical composition of volcanic gases. In: Scarpa M, Tilling RJ (eds) Monitoring and mitigation of Volcanic Hazards Springer; Heidelberg, Germany. p 221-256

Giggenbach WF (1997) The origin and evolution of fluids in magmatic-hydrothermal systems. In: Geochemistry of Hydrothermal Ore Deposits. 3rd Edition. Barnes HL (ed) Wiley, New York, NY, USA. $p$ 737-796

Giggenbach WF, Goguel RL (1989) Collection and analysis of geothermal and volcanic water and gas discharges. Chemical Division of DSIR Report. CD 2401, 81 pp

Giggenbach WF, Le Guern F (1976) The chemistry of magmatic gases from Erta'Ale, Ethiopia. Geochim Cosmochim Acta 40:25-30

Giggenbach WF, Matsuo S (1991) Evaluation of results from Second and Third IAVCEI field workshops on volcanic gases, Mt Usu, Japan, and White Island, New Zealand. Appl Geochm 6:125-141

Giggenbach WF, Tedesco D, Sulistiyo Y, Caprai A, Cioni R., Favara R, Fischer TP, Hirabayashi J-I, Korzhinsky M, Martini M, Menyailov I, Shinohara $H$ (2001) Evaluation of results from the fourth and fifth IAVCEI field workshop on volcanic gases, Volcano island, Italy and Java, Indonesia. J Volcanol Geoth Res 108:157-172

Graf H-F, Feichter J, Langmann B (1997) Volcanic sulfur emissions: Estimates of source strength and its contribution to the global sulfate distribution. J Geophys Res 102:10,727-10,738

Graf H-F, Kirchner, I Robock A, Schult I (1993) Pinatubo eruption winter climate effects: Model versus observation. Clim Dyn 9:81-93

Graf H-F, Langmann B, Feichter J (1998) The contribution of Earth degassing to the atmospheric sulfur budget. Chem Geol 147:131-145

Grutter M, Basaldud R, Rivera C, Harig R, Junkerman W, Caetano E, Delgado-Granados $\mathrm{H}$ (2008) $\mathrm{SO}_{2}$ emissions from Popocatépetl volcano: emission rates and plume imaging using optical remote sensing techniques. Atmos Chem Phys 8:6655-6663 
Guo S, Bluth GJS, Rose WI, Watson IM, Prata AJ (2004) Re-evaluation of $\mathrm{SO}_{2}$ release of the 15 June 1991 Pinatubo eruption using ultraviolet and infrared satellite sensors. Geochem Geophys Geosyst 5:Q04001, doi:101029/2003GC000654

Halmer MM, Schmincke H-U, Graf H-F (2002) The annual volcanic gas input into the atmosphere, in particular into the stratosphere: a global data set for the past 100 years. J Volcanol Geotherm Res 15:511-528

Hammer CU (1977) Past volcanism revealed by Greenland ice sheet impurities. Nature 270:482-486

Hammer CU, Clausen HB, Dansgaard W (1980) Greenland ice sheet evidence of postglacial volcanism and its climatic impact. Nature 288:230-235

Hansen J, Ruedy R, Sato M, Reynolds R (1996) Global surface temperature in 1995: return to prePinatubo level. Geophys Res Lett 23:1665-1668

Herzog M, Graf HF (2010) Applying the three-dimensional model ATHAM to volcanic plumes: Dynamic of large co-ignimbrite eruptions and associated injection heights for volcanic gases. Geophys Res Lett 37, L19807, doi:10.1029/2010GL044986

Heue $K-P$, Brenninkmeijer CAM, Wagner T, Mies K, Dix B, Frie $\beta U$, Martinsson BG, Slemr F, van Velthoven PFJ (2010) Observations of the 2008 Kasatochi volcanic $\mathrm{SO}_{2}$ plume by CARIBIC aircraft DOAS and the GOME-2 satellite. Atmos Chem Phys 10:4699-4713

Hewitt CN (2001) The atmospheric chemistry of sulphur and nitrogen in power station plumes. Atmos Env 35:1155-1170

Hoff RM (1992) Differential $\mathrm{SO}_{2}$ column measurements of the Mt. Pinatubo volcanic plume. Geophys Res Lett 19:175-178

Hoff RM, Millán MM (1981) Remote $\mathrm{SO}_{2}$ mass flux measurements using Cospec. J Air Pollut Control Assoc 31:381-384

Hofmann C, Courtillot V, Feraud G, Rochette P, Yirgu G, Ketefo E and Pik R (1997) Timing of the Ethiopian flood basalt event and implications for plume birth and global change. Nature 389:838-841

Holasek RE, Self S, Woods AW (1996) Satellite observations and interpretation of the 1991 Mount Pinatubo eruption plumes. J Geophys Res 101(B12):27,635-27,655

Holloway JR (1977) Fugacity and activity of molecular species in supercritical fluids. In: Thermodynamics in Geology. Fraser D (ed) Dordrecht, Reidel Publishing Company. p 161-181

Holloway JR (1987) Igneous fluids. Rev Mineral 17:211-232

Horn S, Schmincke HU (2000) Volatile emission during the eruption of Baitoushan Volcano (China/North Korea) ca. 969 AD. Bull Volcanol 61:537-55

Hubberten HW, Nielsen $H$, Puchelt $H$ (1975) The enrichment of ${ }^{34} S$ in the solfataras of the Nea Kameni volcano, Santorini Archipelago, Greece. Chem Geol 16:197-205 
Huntingdon AT (1973) The collection of volcanic gases from Mount Etna. Phil Trans $R$ Soc London 274:119-128

Ilyinskaya E, Oppenheimer C, Mather TA, Kyle P (2010) Chemistry and size distribution of watersoluble aerosol in the plume of Mt Erebus volcano, Antarctica. Geochem Geophys Geosys 11:Q03017, doi:101029/2009GC002855

Jaeschke W, Claude H, Herrmann J (1980) Sources and sinks of atmospheric $\mathrm{H}_{2}$ S. J Geophys Res 85(C10):5639-5644

Jaggar TA (1940) Magmatic gases. Am J Sci 238:313-353

Johansson M, Galle B, Rivera C, Zhang Y (2009a) Tomographic reconstruction of gas plumes using scanning DOAS. Bull Volcanol 71:1169-1178

Johansson M, Galle B, Zhang Y, Rivera C, Chen D, Wyser K (2009b) The dual-beam mini-DOAS technique: Measurements of volcanic gas emission, plume height and plume speed with a single instrument. Bull Volcanol 71:747-751

Johnson MC, Rutherford MJ (1989) Experimentally determined conditions in the Fish Canyon Tuff, Colorado, magma chamber. J Petrol 30:711-737

Kantzas EP, McGonigle AJS, Bryant RG (2009) Comparison of low cost miniature spectrometers for volcanic $\mathrm{SO}_{2}$ emission measurements. Sensors 9:3256-3268

Kantzas EP, McGonigle AJS, Tamburello G, Aiuppa A, Bryant RG (2010) Protocols for UV camera volcanic $\mathrm{SO}_{2}$ measurements. J Volcanol Geotherm Res 194:55-60

Karagulian F, Clarisse L, Clerbaux C, Prata AJ, Hurtmans D, Coheur PF (2010) Detection of volcanic $\mathrm{SO}_{2}$, ash, and $\mathrm{H}_{2} \mathrm{SO}_{4}$ using the Infrared Atmospheric Sounding Interferometer (IASI). J Geophys Res 115:DOOLO2, doi:101029/2009JD012786

Kassi S, Chenevier M, Gianfrani L, Salhi A, Rouillard Y, Ouvrard A, Romanini D (2006) Looking into the volcano with a Mid-IR DFB diode laser and Cavity Enhanced Absorption Spectroscopy. Opt Express 14:11442-11452

Kazahaya K, Shinohara H, Saito G (1994) Excessive degassing of Izu-Oshima volcano: magma convection in a conduit. Bull Volcanol 56:207-216

Kazahaya K, Shinohara H, Uto K, Odai M, Nakahori Y, Mori H, lino H, Miyashita M, Hirabayashi J (2004) Gigantic $\mathrm{SO}_{2}$ emission from Miyakejima volcano, Japan, caused by caldera collapse. Geology $32: 425-428$

Kazahaya R, Mori T, Kazahaya K, Hirabayashi J (2008) Computed tomography reconstruction of $\mathrm{SO}_{2}$ concentration distribution in the volcanic plume of Miyakejima, Japan, by airborne traverse technique using three UV spectrometers. Geophys Res Lett 35:L13816, doi:101029/2008GL034177

Kellerhals T, Tobler L, Brütsch S, Sigl M, Wacker L, Gäggeler HW, Schwikowski M (2010) Thallium as a tracer for preindustrial volcanic eruptions in an ice core record from Illimani, Bolivia. Env Sci Technol 44:888-893 
Keppler $H$ (1999) Experimental evidence for the source of excess sulfur in explosive volcanic eruption Science 284:1652-1654

Keppler $H$ (2010) The distribution of sulfur between haplogranitic melts and aqueous fluids. Geochim Cosmochim Acta 74:645-660

Kern C, Deutschann T, Vogel L, Wöhrbach M, Wagner T, Platt U (2010) Radiative transfer corrections for accurate spectroscopic measurements of volcanic gas emissions. Bull Volcanol 72:233-247

Kern C, Sihler H, Vogel L, Rivera C, Herrera M, Platt U (2009) Halogen oxide measurements at Masaya Volcano, Nicaragua using active long path differential optical absorption spectroscopy. Bull Volcanol 71:659-670

Krueger AJ (1983) Sighting of El Chichón sulfur dioxide clouds with the Nimbus 7 total ozone mapping spectrometer. Science 220:1377-1379

Krueger AJ, Krotkov N, Carn S (2008) El Chichón: the genesis of volcanic sulfur dioxide monitoring from space. J Volcanol Geotherm Res 175:408-414

Krueger AJ, Krotkov NA, Yang K, Carn S, Vicente G, Schroeder W (2009) Applications of satellite-based sulfur dioxide monitoring. IEEE J Sel Top Appl Earth Obs Remote Sens 2:293-298

Krueger AJ, Walter LS, Bhartia PK, Schnetzler CC, Krotkov NA, Sprod I, Bluth GJS (1995) Volcanic sulfur dioxide measurements from the Total Ozone Mapping Spectrometer (TOMS) instruments. J Geophys Res 100:14057-14076

Kusakabe M, Komoda Y, Takano B, Abiko T (2000) Sulfur isotopic effects in the disproportionation reaction of sulfur dioxide in hydrothermal fluids: implicaitons for the $\delta_{34} S$ variations of dissolved bisulfate and elemental sulfur from active crater lakes. J Volcanol Geotherm Res 97:287-307

Le Guern F, Gerlach TM, Nohl A (1982) Field gas chromatograph analyses of gases from a glowing dome at Merapi volcano, Java, Indonesia, 1977, 1978, 1979. J Volcanol Geotherm Res 14:223-245

Lee C, Martin RV, van Donkelaar A, O'Byrne G, Krotkov N, Richter A, Huey LG, Holloway JS (2009a) Retrieval of vertical columns of sulfur dioxide from SCIAMACHY and OMI: Air mass factor algorithm development, validation, and error analysis. J Geophys Res 114:D22303 doi:101029/2009JD012123

Lee C, Richter A, Weber M, Burrows JP (2009b) $\mathrm{SO}_{2}$ Retrieval from SCIAMACHY using the Weighting Function DOAS (WFDOAS) technique: comparison with Standard DOAS retrieval. Atmos Chem Phys 8:6137-6145

Li ZXA, Lee CTA (2005) The constancy of upper mantle $f_{O 2}$ through time inferred from V/Sc ratios in basalts. Earth Planet Sci Lett 228:483-493

Linzon SN, Temple PJ, Pearson RG (1979) Sulfur concentrations in plant foliage andrelated effects. J Air Pollut Cont Assoc 29:520-525.

Longo BM (2009) The Kilauea volcano adult health survey. Nursing Res 58:23-31 
Longo BM, Grunder A, Chuan R, Rossignol A (2005) $\mathrm{SO}_{2}$ and fine aerosol dispersion from the Kilauea plume, Kau district, Hawaii, USA. Geology 33: 217-220

Longo BM, Rossignol A, Green JB (2008) Cardiorespiratory health effects associated with sulphurous volcanic air pollution. Public Health 122: 809-820

Longo BM, Yang W (2008) Acute bronchitis and volcanic air pollution: a community-based cohort study at Kilauea Volcano, Hawai'i, USA. J Toxicol Environ Health A71:1565-1571

Longo BM, Yang W, Green JB, Longo AA, Harris M, Biblione $R$ (2010) An indoor air quality assessment for vulnerable populations exposed to volcanic vog from Kilauea Volcano. Fam Community Health 33:21-31

Louban I, Bobrowski N, Rouwet D, Inguaggiato S, Platt U (2009) Imaging DOAS for volcanological applications. Bull Volcanol 71:753-765

Love SP, Goff F, Counce D, Siebe C, Delgado H (1998) Passive infrared spectroscopy of the eruption plume at Popocatepetl volcano, Mexico. Nature 396:563-567

Love SP, Goff F, Schmidt SC, Counce D, Pettit D, Christenson BW, Siebe C (2000) Passive infrared spectroscopic remote sensing of volcanic gases: ground-based studies at White Island and Ruapehu, New Zealand, and Popocatepetl, Mexico. In: Remote Sensing of Active Volcanism. Mouginis-Mark P, Crisp J, Fink J (Eds) Geophys Monographs 116:117-138

Luhr JF (1990) Experimental phase relations of water-and sulfur-saturated arc magmas and the 1982 eruptions of El Chichòn volcano. J Petrol 31:1071-1114

Luhr JF, Carmichael ISE, Varekamp JC (1984) The 1982 eruptions of El Chichòn Volcano, Chiapas, Mexico: mineralogy and petrology of the anhydrite-bearing pumices. J Volcanol Geotherm Res 23:69108

Luhr JF, Logan MAV (2002) Sulfur isotope systematics of the 1982 El Chichon trachyandesite: An ion microprobe study. Geochim Cosmochim Acta 66:3303-3316

Malinconico LL (1979) Fluctuations in $\mathrm{SO}_{2}$ emission during recent eruptions of Etna. Nature 278:43-45

Mallmann G, O'Neill HC (2009) The crystal/melt partitioning of $V$ during mantle melting as a function of oxygen fugacity compared with some other elements ( $\mathrm{Al}, \mathrm{P}, \mathrm{Ca}, \mathrm{SC}, \mathrm{Ti}, \mathrm{Cr}, \mathrm{Fe}, \mathrm{Ga}, \mathrm{Y}, \mathrm{Zr}$ and $\mathrm{Nb}$ ). J Petrol 50:1765-1794

Mandeville CW, Webster JD, Tappen C, Taylor BE, Timbal A, Sasaki A, Hauri E, Bacon CR (2009) Stable isotope and petrologic evidence for open-system degassing during the climactic and pre-climactic eruptions of Mt. Mazama, Crater Lake, Oregon. Geochim Cosmochim Acta 73:2978-3012

Mannino DM, S Ruben F C Holschuh, TC Holschuh, M D Wilson, T Holschuh (1996) Emergency department visits and hospitalizations for respiratory disease on the island of Hawaii, 1981 to 1991. Hawaii Med J 55:48-53

Marini L, Chiappini V, Cioni R, Cortecci G, Dinelli E, Principe C, Ferrara G (1998) Effect of degassing on sulfur contents and $\delta 34 S$ values in Somma-Vesuvius magmas. Bull Volcanol 60:187-194 
Marini L, Gambardella B, Principe C, Arias A, Brombach T, Hunziker J C (2002) Characterization of magmatic sulfur in the Aegean island arc by means of the $\delta_{34} \mathrm{~S}$ values of fumarolic $\mathrm{H}_{2} \mathrm{~S}$, elemental $\mathrm{S}$, and hydrothermal gypsum from Nisyros. Earth Planet Sci Lett 200:15-31

Marini L, Moretti R, Accornero M (2011) Sulfur isotopes in magmatic-hydrothermal systems, melts, and magmas. Rev Mineral Geochem 73:423-492

Marshall AG, Scaife AA, Ineson S (2009) Enhanced seasonal prediction of European winter warming following volcanic eruptions. J Climate 22:6168-6180

Martel C, Pichavant M, Bourdier J-L, Traineau H, Holtz F, Scaillet B (1998) Magma storage conditions and control of eruption regime in silicic volcanoes: experimental evidence from Mt. Pelée. Earth Planet Sci Lett 156:89-99

Martin D, Ardouin B, Bergametti G, Carbonnelle J, Faivre-Pierret R, Lambert G, Le Cloarec MF, Sennequier G (1986) Geochemistry of sulfur in Mount Etna plume. J Geophys Res 91(B12):12,24912,254

Martin LR, Damschen DE (1981) Aqueous oxidation of sulfur dioxide by hydrogen peroxide at low $\mathrm{pH}$. Atmos Environ 15: 1615-1621

Martin RS, Mather TA, Pyle D, Power M, Allen AG, Aiuppa A, Horwell CJ, Ward EPW (2008) Composition-resolved size distributions of volcanic aerosols in the Mt. Etna plumes. J Geophys Res 113, D17211, doi:10.1029/2007JD009648

Martin RS, Mather TA, Pyle DM (2006) High-temperature mixtures of magmatic and atmospheric gases. Geochem Geophys Geosys 7, Q04006, doi:10.1029/2005GC001186

Martin RS, Mather TA, Pyle DM, Day JA, Witt MLI, Collins SJ, Hilton RG (2010a) Major and trace element distributions around active volcanic vents determined by analyses of grasses: Implications for element cycling and biomonitoring. Bull Volcanol 72:1009-1020

Martin RS, Roberts TJ, Mather TA, Pyle DM (2009) The implications of $\mathrm{H}_{2} \mathrm{~S}$ and $\mathrm{H}_{2}$ stability in high-T mixtures of magmatic and atmospheric gases for the production of oxidized trace species (e.g., $\mathrm{BrO}$ and $N O_{x}$ ). Chem Geol 263:143-150

Martin RS, Sawyer GM, Spampinato L, Salerno GG, Ramirez C, Ilyinskaya E, Witt MLL, Mather TA, Allen AG, Watson IM, Phillips JC, Oppenheimer C (2010b) A total volatile inventory for Masaya volcano, Nicaragua, J Geophys Res 115:B09215, doi:10.1029/2010JB007480

Mather T, Pyle DM, Oppenheimer C (2003a) Tropospheric volcanic aerosol. In: Volcanism and the Earth's atmosphere. Robock A, Oppenheimer C (eds), Am Geophys Union Monograph 139 189-212

Mather TA (2008) Volcanoes and the atmosphere: the potential role of the atmosphere in unlocking the reactivity of volcanic emissions. Phil Trans Roy Soc A 366:4581-4595

Mather TA, Allen AG, Oppenheimer C, Pyle DM, McGonigle AJS (2003b) Size-resolved particle compositions of the tropospheric plume of Masaya volcano, Nicaragua. J Atmos Chem 46(3):207-237 
Mather TA, Tsanev VI, Pyle DM, McGonigle AJS, Oppenheimer C, Allen AG (2004c) Characterization and evolution of tropospheric plumes from Lascar and Villarica volcanoes, Chile. J Geophys Res 109, D21303, doi:10.1029/2004JD004934

Mather TA, Allen AG, Pyle DM, Davison BM, Oppenheimer C and McGonigle AJS (2004a) Nitric acid from volcanoes. Earth Planet Sci Lett 218:17-30

Mather TA, McCabe JR, Rai VK, Thiemens MH, Pyle DM, Heaton THE, Sloane HJ, Fern GR (2006) The oxygen and sulfur isotopic composition of volcanic sulfate aerosol at the point of emission. $J$ Geophys Res 111:D18205, doi:10.1029/2005JD006584

Mather TA, Oppenheimer C, Allen AG, McGonigle AJS (2004b) Aerosol chemistry of emissions from three contrasting volcanoes in Italy. Atmos Environ 38:5637-5649

Mathez EA (1984) Influence of degassing on oxidation states of basaltic magmas. Nature 310:371375

Matthews SJ, Sparks RSJ, Gardeweg MC (1999) The Piedras Grandes-Soncor eruptions, Lascar volcano, Chile; evolution of a zoned magma chamber in the Central Andean upper crust. J Petrol 40:1891-1919

McGee KA (1992) The structure, dynamics and chemical composition of non-eruptive plumes from Mt. St. Helens, 1980-88. J Volcanol Geotherm Res 51:269-282

McGonigle AJS, Aiuppa A, Giudice G, Tamburello G, Hodson AJ, Gurrieri S (2008) Unmanned aerial vehicle measurements of volcanic carbondioxide fluxes. Geophys Res Lett 35:L06303, doi:10.1029/2007GL032508

McGonigle AJS, Delmelle P, Oppenheimer C, Tsanev VI, Delfosse T, Horton H, Williams-Jones G (2004a) $\mathrm{SO}_{2}$ depletion in tropospheric volcanic plumes. Geophys Res Lett 31:L13201, doi:101029/2004GL019990

McGonigle AJS, Hilton DR, Fischer TP, Oppenheimer C (2005) Plume velocity determination for volcanic $\mathrm{SO}_{2}$ flux measurements. Geophys Res Lett 32:L11302, doi:101029/2006GL022470

McGonigle AJS, Oppenheimer C, Galle B, Mather T, Pyle D (2002) Walking traverse and scanning DOAS measurements of volcanic gas emission rates. Geophys Res Lett 29(20):1985 doi: 101029/2002GL015827

McGonigle AJS, Oppenheimer C, Hayes AR, Galle B, Edmonds M, Caltabiano T, Salerno G, Burton M, Mather TA (2003) Sulphur dioxide fluxes from Mount Etna, Vulcano, and Stromboli measured with an automated scanning ultraviolet spectrometer. J Geophys Res 108(B9):2455,

doi:101029/2002JB002261

McGonigle AJS, Oppenheimer C, Tsanev VI, Saunders S, Mulina K, Tohui S, Bosco J, Nahou J, Kuduon J and Taranu $F(2004 b)$ sulphur dioxide fluxes from Papua New Guinea's volcanoes. Geophys Res Lett 31:L08606, doi:101029/2004GL019568 
Menyailov IA, Nikitina LP, Shapar VN, Pilipenko VP (1986) Temperature increase and chemical change of fumarolic gases at Momotombo volcano, Nicaragua, in 1982-1985: are these indicators of a possible eruption? J Geophys Res 91(B12):12,199-12,214

Métrich N, Bertagnini A, Landi P, Rosi M (2001) Crystallisation driven by decompression and water loss at Stromboli volcano (Aeolian Islands, Italy). J Petrol 42:1471-1490

Métrich N, Mandeville CW (2010) Sulfur in magmas. Elements 6:81-86

Métrich N, Sigurdsson H, Meyer PS, Devine JD (1991) The 1783 Lakagigar eruption in Iceland: geochemistry, $\mathrm{CO}_{2}$ and sulfur degassing. Contrib Mineral Petrol 107:435-447

Minnis P, Harrison EF, Stowe LL, Gibson GG, Ddenn FM, Doelling DR, Smith WL Jr. (1993) Radiative climate forcing by the Mount Pinatubo eruption. Science 259 1411-1415

Moffat AJ, Millán MM (1971) The application of optical correlation techniques to the remote sensing of $\mathrm{SO}_{2}$ plumes using skylight. Atmos Environ 5:677-690

Möller D (1980) Kinetic model of atmospheric $\mathrm{SO}_{2}$ oxidation based on published data. Atmos Env 14:1067-1076

Montegrossi G, Tassi F, Minissale AA, Vaselli O, Buccianti A (2008) Natural fluctuation of sulfur species in volcanic fumaroles. J Non-Equilib Thermodyn 33:75-102

Montegrossi G, Tassi F, Vaselli O, Buccianti A, Garofalo K (2001) Sulfur species in volcanic gases. Anal Chem 73:3709-3715

Moretti R, P Papale and G Ottonello (2003) A model for the saturation of C-O-H-S fluids in silicate melts. In: Volcanic degassing. Oppenheimer C, Pyle DM, Barclay J (eds) Geol Soc Spec Pub 213:81-101

Mori T, Burton $\mathrm{M}$ (2006) The $\mathrm{SO}_{2}$ camera: A simple, fast and cheap method for ground-based imaging of $\mathrm{SO}_{2}$ in volcanic plumes. Geophys Res Lett 33, L24804, doi:101029/2006GL027916

Mori T, Burton MR (2009) Quantification of the gas mass emitted during single explosions on Stromboli with the $\mathrm{S}_{\mathrm{O} 2}$ imaging camera. J Volcanol Geotherm Res188: 395-400

Mori T, Kazahaya K, Oppenheimer C, McGonigle AJS, Tsanev V, Olmos R, Ohwada M Shuto T (2006) Sulfur dioxide fluxes from the volcanoes of Hokkaido, Japan. J Volcanol Geotherm Res 158: 235-243

Mori T, Notsu $\mathrm{K}$ (1997) Remote $\mathrm{CO}, \mathrm{COS}, \mathrm{CO}_{2}, \mathrm{SO}_{2}, \mathrm{HCl}$ detection and temperature estimation of volcanic gas. Geophys Res Lett 24(16), 2047-2050, doi:101029/97GL52058

Mori T, Notsu K (2008) Temporal variation in chemical composition of the volcanic plume from Aso volcano, Japan, measured by remote FT-IR spectroscopy. Geochem J 42:133-140

Mori T, Notsu K, Tohjima $\mathrm{Y}$, Wakita $\mathrm{H}$ (1993) Remote detection of $\mathrm{HCl}$ and $\mathrm{SO}_{2}$ in volcanic gas from Unzen Volcano, Japan. Geophys Res Lett 20(13), 1355-1358, doi:101029/93GL01065

Mori T, Notsu K, Tohjima Y, Wakita H, Nuccio PM, Italiano F (1995) Remote detection of fumarolic gas chemistry at Vulcano, Italy, using an FT-infrared spectral radiometer. Earth Planet Sci Lett 134:219224 
Moune S, Holtz F, Botcharnikov RE (2009) Sulphur solubility in andesitic to basaltic melts: implications for Hekla volcano. Contrib Mineral Petrol 157:691-707

Nakada S, Nagai M, Kaneko T, Nozawa A, Suzuki-Kamata K (2005) Chronology and products of the 2000 eruption at Miyakejima. Bull Volcanol 67:205-218

Nakamura T, Okuno M, Kimura K, Mitsutani T, Moriwaki H, Ishizuka Y, Kim KH (2007) Application of

${ }^{14} \mathrm{C}$ wiggle-matching to support dendrochronological analysis in Japan. Tree-Ring Res 63:37-46

Naughton JJ, Derby JV, Glover RB (1969) Infrared measurements on volcanic gas and fume: Kilauea eruption, 1968. J Geophys Res 74(12):3273-3277

Naughton JJ, Heald EF, Barnes IL (1963) The chemistry of volcanic gases 1 Collection and analysis of equilibrium mixtures by gas chromatography. J Geophys Res 68(2):539-544

Németh K, Cronin SJ, White JDL (2007) Kuwae caldera and climate confusion. Open Geol J 1:7-11

Notsu K, Mori T, Igarashi G, Tohjima Y, Wakita H (1993) Infrared spectral radiometer: A new tool for remote measurement of $\mathrm{SO}_{2}$ of volcanic gas. Geochem J 27:361-366

O'Dwyer M, Padgett MJ, McGonigle AJS, Oppenheimer C, Inguaggiato S (2003) Real-time measurement of volcanic $\mathrm{H}_{2} \mathrm{~S}$ and $\mathrm{SO}_{2}$ concentrations by UV spectroscopy. Geophys Res Lett 30(12):1652, doi 101029/2003GL017246

Ohba T, Nogami K, Hirabayashi J, Mori $T$ (2008) Isotopic fractionation of $\mathrm{SO}_{2}$ and $\mathrm{H}_{2} \mathrm{~S}$ gases during the absorption by $\mathrm{KOH}$ solution, with the application to volcanic gas monitoring at Miyakejima Island, Japan. Geochemical J 42:119-131

Oman L, Robock A, Stenchikov G, Schmidt GA, Ruedy R (2005) Climatic response to high-latitude volcanic eruptions. J Geophys Res 110:D13103, doi:101029/2004JD005487

Oppenheimer C (1992) Sulphur eruptions at Volcán Poás, Costa Rica. J Volcanol Geotherm Res 49:121

Oppenheimer C (2002) Limited global change due to largest known Quaternary eruption, Toba $\approx 74$ kyr BP? Quat Sci Rev 21:1593-1609

Oppenheimer C (2003) Ice core and palaeoclimatic evidence for the great volcanic eruption of 1257. Int J Climatol 23:417-426

Oppenheimer C (2010) Ultraviolet sensing of volcanic sulfur emissions. Elements 6:87-92

Oppenheimer C (2011) Eruptions That Shook the World. Cambridge University Press

Oppenheimer C, Burton MR, Durieux J, Pyle DM (2002a) Open-path Fourier transform spectroscopy of gas emissions from a carbonatite volcano: Oldoinyo Lengai, Tanzania. Optics Lasers Eng 37:203-214 
Oppenheimer C, Edmonds M, Francis $P$, Burton MR (2002b) Variation in $\mathrm{HCl} / \mathrm{SO}_{2}$ gas ratios observed by Fourier transform spectroscopy at Soufrière Hills Volcano, Montserrat. In: The eruption of Soufrière Hills Volcano, Montserrat, from 1995 to 1999. Druitt TH, Kokelaar P (eds) Geol Soc Lond Mem 21:621639

Oppenheimer C, Francis P, Burton M, Maciejewski A, Boardman L (1998a) Remote measurement of volcanic gases by Fourier transform infrared spectroscopy. Appl Phys B 67:505-515

Oppenheimer C, Francis P, Stix J (1998b) Depletion rates of $\mathrm{SO}_{2}$ in tropospheric volcanic plumes. Geophys Res Lett 25:2671-2674

Oppenheimer C, Kyle PR (2008) Probing the magma plumbing of Erebus volcano, Antarctica, by openpath FTIR spectroscopy of gas emissions. J Volcanol Geotherm Res 177:743-754

Oppenheimer C, Kyle PR, Tsanev VI, McGonigle AJS, Mather TA, Sweeney D (2005) Mt Erebus, the largest point source of $\mathrm{NO}_{2}$ in Antarctica. Atmos Env 39:6000-6006

Oppenheimer C, Lomakina A, Kyle PR, Kingsbury NG, Boichu M (2009) Pulsatory magma supply to a phonolite lava lake. Earth Planet Sci Lett 284:392-398

Oppenheimer C, Moretti R, Kyle P, Eschenbacher A, Lowenstern J, Hervig R (2011) Mantle to surface degassing of alkalic magmas at Erebus volcano., Antarctica. Earth Planet Sci Lett, doi:10.1016/j.epsl.2011.04.005

Oppenheimer C, Kyle P, Eisele JF, Crawford GJ, Huey DG, Tanner SD, Kim LS, Mauldin DL, Blake AD, Beyersdorf MA, Buhr M, Davis D (2010) Atmospheric chemistry of an Antarctic volcanic plume. J Geophys Res, 115 D04303, doi:101029/2009JD011910

Oppenheimer C, Tsanev VI, Braban CF, Cox RA, Adams JW, Aiuppa A, Bobrowski N, Delmelle P, Barclay J, McGonigle AJS (2006) BrO formation in volcanic plumes. Geochim Cosmochim Acta 70:2935-2941

Parker DE, Wilson H, Jones PD, Christy JR, Folland CK (1996) The impact of Mount Pinatubo on worldwide temperatures. Int J Climatol 16:487-197

Parnell RA (1986) Processes of soil acidification in tropical durandepts, Nicaragua. Soil Sci 42:43-55

Percy KE, Baker EA (1988) Effects of simulated acid rain on leaf wettability, rain retention and uptake of some inorganic ions. New Phytol 108: 75-82

Perret FA (1909) Vesuvius: characteristics and phenomena of the present repose-period. Am J Sci 28:413-430

Perret FA (1950) Volcanological observations. Carnegie Inst Wash Publ 549: 162pp

Picardi G (1982) Fumaroles gas collection and analysis. Bull Volcanol 45:257-260

Pichavant M, Di Carlo I, Le Gac Y, Rotolo S, Scaillet, B (2009) Experimental constraints on the deep magma feeding system at Stromboli volcano, Italy. J Petrol 50:601-624

Platt U, Stutz J (2008) Differential Optical Absorption Spectroscopy: Principles and applications. Springer-Verlag, Heidelberg, $272 p p$ 
Porter JN, Horton K, Mouginis-Mark P, Lienert B, Lau E, Sutton AJ, Elias T, Oppenheimer C (2002) Sun photometer and lidar measurements of the plume from the Hawaii Kilauea volcano Pu' $\mathrm{C}$ 'O'o vent: estimates of aerosol flux rates and $\mathrm{SO}_{2}$ lifetime. Geophys Res Lett doi:101029/2002GL014744

Prata AJ, Bernardo C (2007) Retrieval of volcanic $\mathrm{SO}_{2}$ column abundance from Atmospheric Infrared Sounder data. J Geophys Res 112, D20204, doi:101029/2006JD007955

Prata AJ, Kerkmann J (2007) Simultaneous retrieval of volcanic ash and $\mathrm{SO}_{2}$ using MSG-SEVIRI measurements. Geophys Res Lett 34, L05813, doi:101029/2006GL028691

Putirka KD (2008) Thermometers and barometers for volcanic systems. In: Putirka KD, Tepley F(eds). Rev Mineral Geochem 69:61-120

Pyle DM, Beattie PD, Bluth GJS (1996) Sulphur emissions to the stratosphere from explosive volcanic eruptions. Bull Volcanol 57:663-671

Radke LF (1982) Sulphur and sulphate from Mt Erebus. Nature 299:710-712

Raga GB, Kok GL, Baumgardner D (1999) Evidence for volcanic influence on Mexico City aerosols. Geophys Res Lett 26:1149-1152

Rampino MR, Stothers $R$ (1988) Flood basalt volcanism during the past 250 million years. Science 241:663-668

Read WG, Froidevaux L, Waters JW (1993) Microwave Limb Sounder measurements of stratospheric $\mathrm{SO}_{2}$ from the Mt. Pinatubo eruption. Geophys Res Lett 20:1299-1302

Richter D, Erdelyi M, Curl RF, Tittel FK, Oppenheimer C, Duffell HJ, Burton M (2002) Field measurement of volcanic gases using tunable diode laser based mid-infrared and Fourier transform infrared spectrometers. Opt Lasers Eng 37:171-186

Roberge J, Delgado-Granados $\mathrm{H}$, Wallace PJ (2009) Mafic magma recharge supplies high $\mathrm{CO}_{2}$ and $\mathrm{SO}_{2}$ gas fluxes from Popocatépetl volcano, Mexico. Geology 37:107-110

Roberts TJ, Braban CF, Martin RS, Oppenheimer C, Adams JW, Cox RA, Jones RL, Griffiths PT (2009) Modelling reactive halogen formation and ozone depletion in volcanic plumes. Chem Geol 263:110121

Roberts TJ, Braban CF, Oppenheimer C, Freshwater R, Martin RS, Dawson DH, Griffiths PT, Cox RA, Safell J, Jones RL (2011) Electrochemical sensing of volcanic gases. Chem Geol, in revision

Robock A (2005) Cooling following large volcanic eruptions corrected for the effect of diffuse radiation on tree rings. Geophys Res Lett 32, L06702, doi:101029/2004GL022116

Rocco A, De Natale G, De Natale P, Gagliardi G, Gianfrani L (2004) A diode-laser-based spectrometer for in-situ measurements of volcanic gases. Appl Phys B 78:235-240

Rodriguez LA, Watson IM, Edmonds M, Ryan G, Hards V, Oppenheimer C, Bluth GJS (2008) $\mathrm{SO}_{2}$ loss rates in the plume emitted by Soufriere Hills volcano, Montserrat. J Volcanol Geotherm Res 173:135147 
Roeder PL, Thornber C, Grant A (2004) Reply to comment on paper: "Morphology and composition of spinel in Pu'u 'O'o lava (1996-1998), Kilauea volcano, Hawaii"-enigmatic discrepancies between lava and gas-based $f_{O 2}$ determinations of Pu'u 'O'o lava. J Volcanol Geotherm Res 134:245-248

Rose WI, Chuan RL, Giggenbach WF, Kyle PR, Symonds RB (1986) Rates of sulfur dioxide and particle emissions from White Island volcano, New Zealand, and an estimate of the total flux of major gaseous species. Bull Volcanol 48:181-188

Rose WI, Stoiber RE, Malinconico LL (1982) Eruptive gas compositions and fluxes of explosive volcanoes: budget of $S$ and $\mathrm{Cl}$ emitted from Fuego volcano, Guatemala. In: Andesite: orogenic andesites and related rocks. Thorpe RS (ed) Wiley \& Sons. $p$ 669-676

Rutherford MJ, Devine JD (1996) Pre-eruption pressure-temperature conditions and volatiles in the 1991 Mount Pinatubo magma. In: Fire and Mud: Eruptions and Lahars of Mount Pinatubo. Quezon City: Philippine Institute of Volcanology and Seismology; Seattle, WA. Newhall CG, Punongbayan RS (eds) University of Washington Press, p. 751-766

Rutherford MJ, Sigurdsson H, Carey S (1985) The May 1, 1980 eruption of Mount St Helens: 1, Melt composition and experimental phase equilibria. J Geophys Res 90:2929-2947

Saal $A E$, Hauri $E H$, Langmuir $C H$, Perfit MR (2002) Vapor undersaturation in primitive midocean ridge basalt and the volatile content of Earth's upper mantle. Nature 419:451-455

Sakai H, Casadevall TJ, Moore JG (1982) Chemistry and isotope ratios of sulfur in basalts and volcanic gases at Kilauea Volcano, Hawaii. Geochim Cosmochim Acta 46:729-738

Salerno GG, Burton M, Oppenheimer C, Caltabiano T, Randazzo D, Bruno N, Longo V (2009b) Threeyears of $\mathrm{SO}_{2}$ flux measurements of Mt. Etna using an automated UV scanner array: comparison with conventional traverses and uncertainties in flux retrieval. J Volcanol Geotherm Res 183:76-83.

Salerno GG, Burton MR, Oppenheimer C, Caltabiano T, Tsanev VI, Bruno N, Randazzo D (2009a) Novel retrieval of volcanic $\mathrm{SO}_{2}$ abundance from ultraviolet spectra. J Volcanol Geotherm Res 181:141-153

Sarda P, Graham D (1990) Mid-ocean ridge popping rocks: implications for degassing at ridge crests. Earth Planet Sci Lett 97:268-289

Savarino J, Bekki S, Cole-Dai J, Thiemens MH (2003a) Evidence from sulfate mass independent oxygen isotopic compositions of dramatic changes in atmospheric oxidation following massive volcanic eruptions. J Geophys Res 108(D21), 4671, doi:10.1029/2003JD003737

Savarino J, Romero A, Cole-Dai J, Bekki S, Thiemens MH (2003b) UV induced mass-independent sulfur isotope fractionation in stratospheric volcanic sulphate. Geophys Res Lett 30(21), 2131, doi:10.1029/2003GL018134

Sawyer GM, Oppenheimer C, Tsanev VI, Yirgu G (2008a) Magmatic degassing at Erta 'Ale volcano, Ethiopia. J Volcanol Geotherm Res 178:837-846

Sawyer GM, Carn SA, Tsanev VI, Oppenheimer C, Burton M (2008b) Investigation into magma degassing at Nyiragongo volcano, Democratic Republic of the Congo. Geochem Geophys Geosyst 9, Q02017, doi:101029/2007GC001829 
Scaillet B, Clemente B, Evans BW, Pichavant M (1998) Redox control of sulfur degassing in silicic magmas. J Geophys Res 103:23937-23949

Scaillet B, Evans BW (1999) The 15 June 1991 eruption of Mount Pinatubo. I. Phase equilibria and preeruption $P-T-f_{\mathrm{O} 2}-f_{\mathrm{H} 2 \mathrm{O}}$ conditions of the dacite magma. J Petrol 40:381-411.

Scaillet B, Luhr JF, Carroll MC (2003) Petrological and volcanological constraints on volcanic sulfur emissions to the atmosphere In: Volcanism and the Earth's Atmosphere. Robock A, Oppenheimer $C$ (eds) Geophysical Monograph 139:11-40

Scaillet B, Macdonald R (2006) Experimental and thermodynamic constraints on the sulphur yield of peralkaline and metaluminous silicic flood eruptions. J Petrol 47:1413-1437

Scaillet B, Pichavant M (2003) Experimental constraints on volatile abundances in arc magmas and their implications for degassing processes. In: Volcanic Degassing. Oppenheimer C, Pyle DM, Barclay J (eds) Geol Soc Lond Spec Pub 213:23-52.

Scaillet B, Pichavant M (2004) Earth Science: Role of $f_{02}$ in fluid saturation of oceanic basalt. Nature 430, doi:10.1038/nature02814

Scaillet B, Pichavant M (2005) A model of sulphur solubility for hydrous mafic melts: application to the determination of magmatic fluid compositions of Italian volcanoes. Ann Geophys 48:671-698

Schiano P, Clocchiatti R, Ottolini L (2001) Transition of Mount Etna lavas from a mantle plume to an island-arc magmatic source. Nature 412:900-904

Schneider DP, Ammann CM, Otto-Bliesner BL, Kaufman DS (2009) Climate response to large, highlatitude and low-latitude volcanic eruptions in the Community Climate System Model. J Geophys Res 114:D15101, doi:101029/2008JD011222

Self S, Blake S, Sharma K, Widdowson M, Sephton S (2008) Sulfur and chlorine in Late Cretaceous Deccan magmas and eruptive gas release. Science 319:1654-1657

Self S, R Gertisser, T Thordarson, M R Rampino, J A Wolff (2004) Magma volume, volatile emissions, and stratospheric aerosols from the 1815 eruption of Tambora. Geophys Res Lett 31:L20608, doi:101029/2004GL020925

Sharma K, Blake S, Self S, Krueger AJ (2004) $\mathrm{SO}_{2}$ emissions from basaltic eruptions, and the excess sulfur issue. Geophys Res Lett 31:L13612, doi:101029/2004GL019688

Shinohara $H$ (2005) A new technique to estimate volcanic gas composition: plume measurements with a portable multi-sensor system. J Volcanol Geotherm Res 143:319-333

Shinohara $H$ (2008) Excess degassing from volcanoes and its role on eruptive and intrusive activity. Rev Geophys 46:RG4005, doi:101029/2007RG000244

Shock EL, Holland M, Meyer-Dombard D'A, Amend JP, Osburn GR, Fischer TP (2010) Quantifying inorganic sources of geochemical energy in hydrothermal ecosystems, Yellowstone National Park, USA. Geochim Cosmochim Acta 74:4005-4043 
Sigurdsson H, Carey S, Palais JM, Devine J (1990) Pre-eruption compositional gradients and mixing of andesite and dacite magma erupted from Nevado del Ruiz Volcano, Colombia in 1985. J Volcanol Geotherm Res 4:127-151

Smith WH (1990) Air Pollution and Forests: Interaction Between Air Contaminants and Forest Ecosystems. Springer-Verlag, New York, pp 618

Sortino F, Nonell A, Toutain JP, Munoz M, Valladon M, Volpicelli G (2006) A new method for sampling fumarolic gases: Analysis of major, minor and metallic trace elements with ammonia solutions. $J$ Volcanol Geotherm Res 158:244-256

Spilliaert N, Allard P, Métrich N, Sobolev AV (2006) Melt inclusion record of the conditions of ascent, degassing, and extrusion of volatile-rich alkali basalt during the powerful 2002 flank eruption of Mount Etna (Italy). J Geophys Res 111(B4) B04203, doi: 10.1029/2005JB003934

Stenchikov G, Delworth TL, Ramaswamy V, Stouffer RJ, Wittenberg A, Zeng F (2009) Volcanic signals in oceans. J Geophys Res 114:D16104, doi:101029/2008JD011673

Stenchikov G, Hamilton K, Stouffer RJ, Robock A, Ramaswamy V, Santer B, Graf H-F (2006) Arctic Oscillation response to volcanic eruptions in the IPCC AR4 climate models. J Geophys Res 111:D07107, doi:101029/2005JD006286

Stenchikov G, Robock A, Ramaswamy V, Schwarzkopf M D, Hamilton K, Ramachandran S (2002) Arctic Oscillation response to the 1991 Mount Pinatubo eruption: effects of volcanic aerosols and ozone depletion, J Geophys Res 107(D24):4803, 101029/2002JD002090

Stevenson DS, Johnson CE, Collins WJ, Derwent RG (2003) The tropospheric sulphur cycle and the role of volcanic $\mathrm{SO}_{2}$. In: Volcanic Degassing (Oppenheimer C, Pyle DM, Barclay J (eds) Geol Soc Lond Spec Pub 213:295-305

Stith JL, Hobbs PV, Radke LF (1978) Airborne particle and gas measurements in the emissions from six volcanoes. J Geophys Res 83(C8):4009-4017

Stix J, Zapata JA, Calvache M, Cortes GP, Fischer TP, Gomez D, Narvaez L, Ordonez M, Ortega A, Torres R, Williams SN (1993) A model of degassing at Galeras volcano, Colombia, 1988-1993. Geology 21:963-96

Stoiber RE, Bratton G (1978) Airborne correlation spectrometer measurements of $\mathrm{SO}_{2}$ in eruption clouds of Guatemalan volcanoes. EOS Trans Am Geophys Union 59:122

Stoiber RE, Malinconico Jr, LL, Williams SN (1983) Use of the Correlation Spectrometer at Volcanoes. In: Forecasting Volcanic Events, Tazieff H, Sabroux J-C (eds), Elsevier, Amsterdam. p. 425-424

Sutton AJ, Elias T (1993) Volcanic gases create air pollution in the Island of Hawaii. Earthquakes Volcanoes 24:178-196

Sutton AJ, Elias T, Gerlach TM, Stokes JB (2001) Implications for eruptive processes as indicated by sulfur dioxide emissions from Kilauea Volcano, Hawai'i, 1979-1997. J Volcanol Geotherm Res 108:283-302 
Sutton AJ, Elias T, Kauahikaua J (2003) Lava-effusion rates for the Pu'u 'O'o-Küpaianaha eruption derived from $\mathrm{SO}_{2}$ emissions and very low frequency (VLF) measurements. USGS Prof Paper 1676:137148

Swanson DA, Casadevall TJ, Dzurisin D, Malone SD, Newhall CG, Weaver CS (1983) Predicting eruptions at Mount St. Helens, June 1980 through December 1982. Science 221:1369-1376

Symonds RB, Reed MH (1993) Calculation of multicomponent chemical-equilibria in gas-solid-liquid systems: Calculation methods, thermochemical data, and applications to studies of high temperature volcanic gases with examples from Mount St Helens. Am J Sci 293:758-864

Symonds RB, WI Rose, GJS Bluth, TM Gerlach (1994) Volcanic gas studies: methods, results, and applications. Rev Mineral 30:1-60

Takano B, Koshida M, Fujiwara Y, Sugimori K, Takayanagi S (1997) Influence of sulfur-oxidizing bacteria on the budget of sulfate in Yugama crater lake, Kusatsu-Shirane volcano, Japan. Biogeochem $38: 227-253$

Thomas MA, Giorgetta MA, Timmreck C, Graf H-F, Stenchikov G (2009a) Simulation of the climate impact of Mt Pinatubo eruption using ECHAM5 - Part 2: Sensitivity to the phase of the QBO and ENSO. Atmos Chem Phys 9:3001-3009

Thomas MA, Timmreck C, Giorgetta MA, Graf H-F, Stenchikov G (2009b) Simulation of the climate impact of Mt Pinatubo eruption using ECHAM5 - Part 1: Sensitivity to the modes of atmospheric circulation and boundary conditions. Atmos Chem Phys 9:757-769

Thordarson T, Self S, Oskarsson N, Hulsebosch T (1996) Sulfur, chlorine, and fluorine degassing and atmospheric loading by the 1783-1784 AD Laki (Skaftar Fires) eruption in Iceland. Bull Volcanol 58:205-225

Timmreck C, Graf H-F (2006) The initial dispersal and radiative forcing of a Northern Hemisphere midlatitude super volcano: a model study. Atmos Chem Phys 6:35-49

Timmreck C, Graf H-F, Lorenz SJ, Niemeier U, Zanchettin D, Matei D, Jungclaus JH, Crowley TJ (2010) Aerosol size confines climate response to volcanic super-eruptions. Geophys Res Lett 37:L24705, doi:10.1029/2010GL045464

Timmreck C, Lorenz SJ, Crowley TJ, Kinne S, Raddatz TJ, Thomas MA, Jungclaus JH (2009) Limited temperature response to the very large AD 1258 volcanic eruption. Geophys Res Lett 36:L21708, doi:101029/2009GL040083

Toutain JP, Baubron J-C, François L (2002) Runoff control of soil degassing at an active volcano: The case of Piton de la Fournaise, Réunion Island. Earth Planet Sci Let 197:83-94

Traversi R, Becagli S, Castellano E, Marino F, Rugi F, Severi M, de Angelis M, Fischer H, Hansson $M$, Stauffer M, Steffensen JP, Bigler M, Udisti R (2009) Sulfate spikes in the deep layers of EPICA-Dome C ice core: evidence of glaciological artifacts. Environ Sci Technol 43:8737-8743

Trenberth KE, Dai A (2007) Effects of Mount Pinatubo volcanic eruption on the hydrological cycle as an analog of geoengineering. Geophys Res Lett 34, L15702, doi:101029/2007GL030524 
Viane C, Bhugwant C, Sieja B, Staudacher T, Demoly P (2009) Comparative study of the volcanic gas emissions and the hospitalizations for asthma of the Reunion island population between 2005 and 2007. Revue Française d'Allergologie 49:346-351

von Glasow R (2010) Atmospheric chemistry in volcanic plumes. Proc Natl Acad Sc 107:6594-6599

von Glasow R, Bobrowski N, Kern C (2009) The effects of volcanic eruptions on atmospheric chemistry. Chem Geol 262:131-142

Wallace PJ (2001) Volcanic $\mathrm{SO}_{2}$ emissions and the abundance and distribution of exsolved gas in magma bodies. J Volcanol Geotherm Res 108:85-106

Wallace PJ (2002) Volatiles in submarine basaltic glasses from the Northern Kerguelen plateau (ODP site 1140): implications for source region compositions, magmatic processes, and plateau subsidence. J Petrol 43:1311-1326

Wallace PJ, Anderson AT (1998) Effects of eruption and lava drainback on the $\mathrm{H}_{2} \mathrm{O}$ contents of basaltic magmas at Kilauea. Bull Volcanol 59:327-344

Wallace PJ, Anderson AT, Davis AM (1995) Quantification of pre-eruptive exsolved gas contents in silicic magmas. Nature 377:612-5

Wallace PJ, Anderson AT, Davis AM (1999) Gradients in $\mathrm{H}_{2} \mathrm{O}, \mathrm{CO}_{2}$, and exsolved gas in a large-volume silicic magma system: Interpreting the record preserved in melt inclusions from the Bishop Tuff. $J$ Geophys Res 104(B9):20,097-20,122

Wallace PJ, Carmichael ISE (1992) Sulfur in basaltic magmas. Geochim Cosmochim Acta 56:16831874

Wallace PJ, Edmonds M (2011) The sulfur budget in magmas: evidence from melt inclusions, submarine glasses, and volcanic gas emissions. Rev Mineral Geochem 73:215-246

Wallace PJ, Gerlach TM (1994) Magmatic vapor source for sulfur dioxide released during volcanic eruptions: evidence from Mount Pinatubo. Science 265:497-499

Watson IM, Oppenheimer C, Voight B, Francis PW, Clarke A, Stix J, Miller A, Pyle DM, Burton MR, Young SR, Norton G, Loughlin S, Darroux B, MVO Staff (2000) The relationship between degassing and deformation at Soufriere Hills volcano, Montserrat. J Volcanol Geotherm Res 98:117-126

Watson IM, Realmuto VJ, Rose WI, Prata AJ, Bluth GJS, Gu Y, Bader CE, Yu T (2004) Thermal infrared remote sensing of volcanic emissions using the moderate resolution imaging spectroradiometer. $J$ Volcanol Geotherm Res 135:75-89

Webster JD, Botcharnikov RE (2011) Distribution of sulfur between melt and fluid in S-O-H-C-Clbearing magmatic systems at shallow crustal pressures and temperatures. Rev Mineral Geochem 73:247-283

Webster JD, Sintoni MF, De Vivo B (2009) The partitioning behavior of $\mathrm{Cl}$ and $\mathrm{S}$ in aqueous fluid-and saline-liquid saturated phonolitic and trachytic melts at 200 MPa. Chem Geol 263:19-36 
Weibring P, Edner H, Svanberg S, Cecchi G, Pantani L, Ferrara R, Caltabiano T (1998) Monitoring of volcanic sulphur dioxide emissions using differential absorption lidar (DIAL), differential optical absorption spectroscopy (DOAS), and correlation spectroscopy (COSPEC). Appl Phys B 67:419-426

Weibring P, Swartling J, Edner H, Svanberg S, Caltabiano T, Condarelli D, Cecchi G, Pantani L (2002) Optical monitoring of volcanic sulphur dioxide emissions-comparison between four different remotesensing spectroscopic techniques. Opt Lasers Eng 37:267-284

Weidmann D, Roller C, Tittel FK, Curl RF, Uehara K, Oppenheimer C, De Natale P (2003) Development of a $43 \mu \mathrm{m}$ quantum cascade laser based ${ }^{13} \mathrm{CO}_{2} /{ }^{12} \mathrm{CO}_{2}$ isotopic ratio sensor. Abstract, ISI 2003, Second International Symposium on Isotopomers, Stresa, 4-7 November 2003

Westrich HR, Gerlach TM (1992) Magmatic gas source for the stratospheric $\mathrm{SO}_{2}$ cloud from the June 15, 1991 eruption of Mount Pinatubo. Geology 20:867-70

Wignall PB (2001) Large igneous provinces and mass extinctions. Earth Sci Rev 53:1-33

Williams SN, Stoiber RE, Garcia NP, Londono AC, Gemmell JB, Lowe DR, Connor CB (1986) Eruption of the Nevado del Ruiz volcano, Colombia on 13 november 1985: gas flux and fluid geochemistry.

Science 233:964-967.

Williams-Jones G, Horton KA, Elias T, Garbeil H, Mouginis-Mark PJ, Sutton AJ, Harris AJL (2006) Accurately measuring volcanic plume velocity with multiple UV spectrometers. Bull Volcanol 68:328332

Williams-Jones G, Stix J, Hickson C (eds) (2008) The COSPEC cookbook: making $\mathrm{SO}_{2}$ gas measurements at active volcanoes. IAVCEI Methods in Volcanology 1. Published online:

http://www.iavcei.org/IAVCEI_publications/COSPEC/COSPEC_Cookbook.html

Winner WE, Mooney HA (1980) Responses of Hawaiian plants to volcanic sulfur dioxide: stomatal behavior and foliar injury. Science 210:789-791

Witham CS, Oppenheimer C (2005) Mortality in England during the 1783-4 Laki Craters eruption. Bull Volcanol 67:15-26

Witham CS, Oppenheimer C, Horwell CJ (2005) Volcanic ash-leachates: a review and recommendations for sampling methods. J Volcanol Geotherm Res 141:299-326

Witt MLI, Mather TA, Pyle DM, Aiuppa A, Bagnato E, Tsanev VI (2008) Mercury and halogen emissions from Masaya and Telica volcanoes, Nicaragua. J Geophys Res 113:B06203,

doi:10.1029/2007JB005401

Witter JB, Self S (2007) The Kuwae (Vanuatu) eruption of AD 1452: potential magnitude and volatile release. Bull Volcanol 69:301-318

Wong $T$, Wielicki BA, Lee RB, Smith GL, Bush $K$ (2006) Re-examination of the observed decadal variability of Earth Radiation Budget using altitude-corrected ERBE/ERBS nonscanner WFOV data. J Climate 19:4028-4040 
Wright TE, Burton M, Pyle DM, Caltabiano $T$ (2008) Scanning tomography of $\mathrm{SO}_{2}$ distribution in a volcanic gas plume. Geophys Res Lett 35: L17811, doi:10.1029/2008GL034640

Yamamoto H, Watson IM, Phillips JC, Bluth GJ (2008) Rise dynamics and relative ash distribution in vulcanian eruption plumes at Santiaguito Volcano, Guatemala, revealed using an ultraviolet imaging camera. Geophys Res Lett 35, L08314, doi:101029/2007GL032008

Yang K, Krotkov NA, Krueger AJ, Carn SA, Bhartia PK, Levelt PF (2007) Retrieval of large volcanic $\mathrm{SO}_{2}$ columns from the Aura Ozone Monitoring Instrument: Comparison and limitations. J Geophys Res 112:D24S43 doi:101029/2007JD008825

Yang K, Krotkov NA, Krueger AJ, Carn SA, Bhartia PK, Levelt PF (2009a), Improving retrieval of volcanic sulfur dioxide from backscattered UV satellite observations. Geophys Res Lett 36:L03102, doi:10.1029/2008GL036036

Yang K, Liu X, Krotkov NA, Krueger AJ, Carn SA (2009b) Estimating the altitude of volcanic sulfur dioxide plumes from space borne hyper-spectral UV measurements. Geophys Res Lett 36:L10803, doi:101029/2009GL038025

Zapata G, Calvache ML, Cortés GP, Fischer TP, Garzon V, Gómez MD, Narváez ML, Ordoñez VM, Ortega EA, Stix, J, Torres CR, Williams SN (1997) SO2 fluxes from Galeras volcano, Colombia 19891995: Progressive degassing and conduit obstruction of a Decade Volcano. J Volcanol Geotherm Res 77:195-208

Zhang $Y$ (1999) $\mathrm{H}_{2} \mathrm{O}$ in rhyolitic glasses and melts: measurement, speciation, solubility, and diffusion. Rev Geophys 37:493-516

Zielinski GA, Mayewski PA, Meeker LD, Whitlow S, Twickler MS (1996) A 110,000-yr record of explosive volcanism from the GISP2 (Greenland) ice core. Quat Res 45:109-118

Zielinski GA, Mayewski PA, Meeker LD, Whitlow S, Twickler MS, Morrison M, Meese DA, Gow AJ Alley $R B$ (1994) Record of volcanism since 7000 BC from the GISP2 Greenland ice core and implications for the volcano-climate system. Science 264:948-952 